Prepared in cooperation with Nye County, Nevada, and the U.S. Department of Energy, National Nuclear Security Administration Nevada Site Office under Interagency Agreement DE-NA0001654

\title{
Groundwater Discharge by Evapotranspiration, Flow of Water in Unsaturated Soil, and Stable Isotope Water Sourcing in Areas of Sparse Vegetation, Amargosa Desert, Nye County, Nevada
}

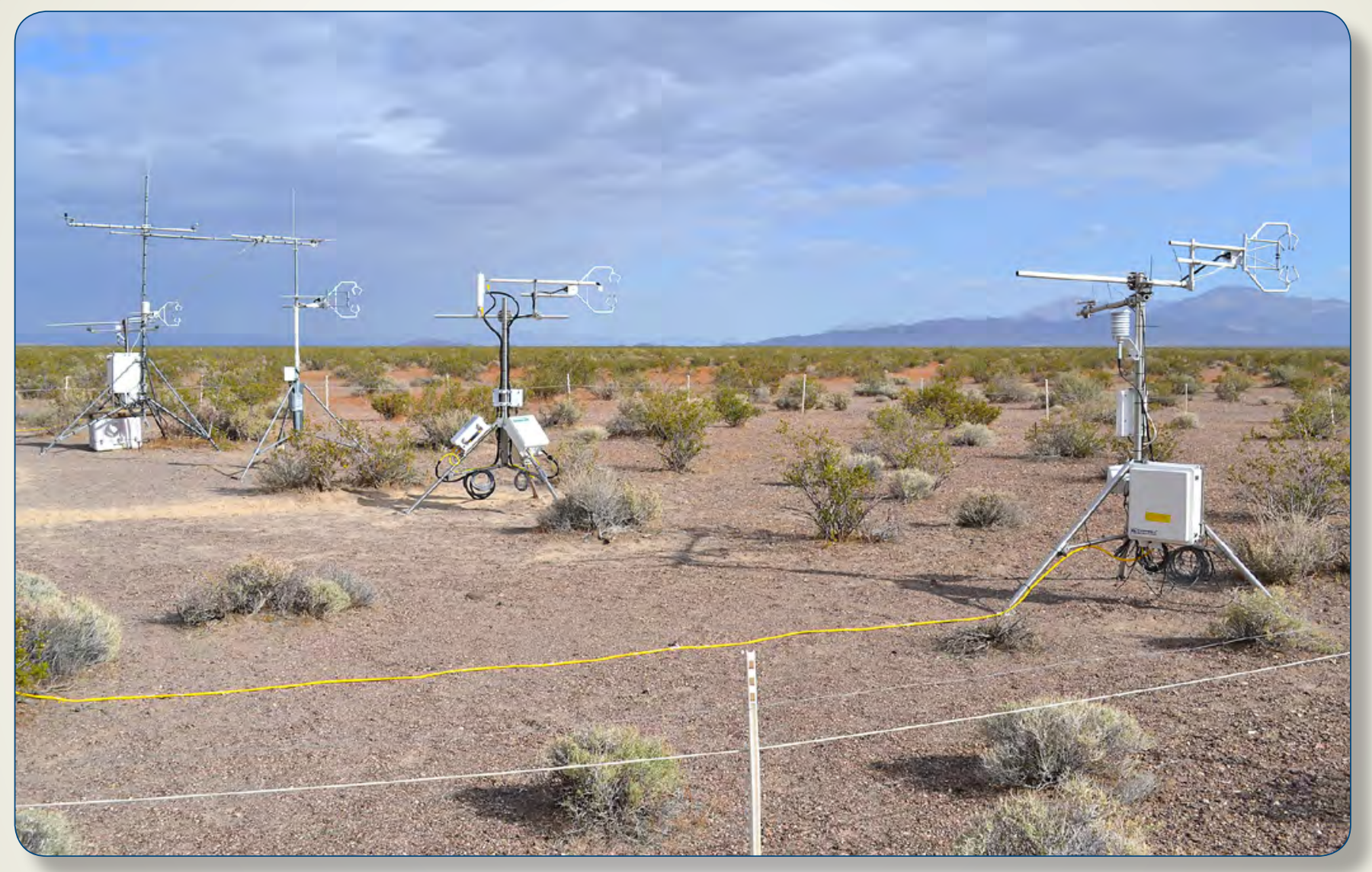

Scientific Investigations Report 2017-5079 
Cover: Photograph showing eddy-covariance station intercomparison, Amargosa

Desert Research Site, Nye County, Nevada. Photograph taken by Michael T. Moreo,

U.S. Geological Survey, May 2011. 


\section{Groundwater Discharge by Evapotranspiration, Flow of Water in Unsaturated Soil, and Stable Isotope Water Sourcing in Areas of Sparse Vegetation, Amargosa Desert, Nye County, Nevada}

By Michael T. Moreo, Brian J. Andraski, and C. Amanda Garcia

Prepared in cooperation with Nye County, Nevada, and the U.S. Department of Energy, National Nuclear Security Administration Nevada Site Office under Interagency Agreement DE-NA0001654

Scientific-Investigations Report 2017-5079 


\title{
U.S. Department of the Interior \\ RYAN K. ZINKE, Secretary
}

\section{U.S. Geological Survey William H. Werkheiser, Acting Director}

\author{
U.S. Geological Survey, Reston, Virginia: 2017
}

For more information on the USGS - the Federal source for science about the Earth, its natural and living resources, natural hazards, and the environment-visit https://www.usgs.gov or call 1-888-ASK-USGS.

For an overview of USGS information products, including maps, imagery, and publications, visit https://store.usgs.gov.

Any use of trade, firm, or product names is for descriptive purposes only and does not imply endorsement by the U.S. Government.

Although this information product, for the most part, is in the public domain, it also may contain copyrighted materials as noted in the text. Permission to reproduce copyrighted items must be secured from the copyright owner.

Suggested citation:

Moreo, M.T., Andraski, B.J., and Garcia, C.A., 2017, Groundwater discharge by evapotranspiration, flow of water in unsaturated soil, and stable isotope water sourcing in areas of sparse vegetation, Amargosa Desert, Nye County, Nevada: U.S. Geological Survey Scientific Investigations Report 2017-5079, 55 p., https://doi.org/10.3133/ sir20175079.

ISSN 2328-0328 (online) 


\section{Contents}

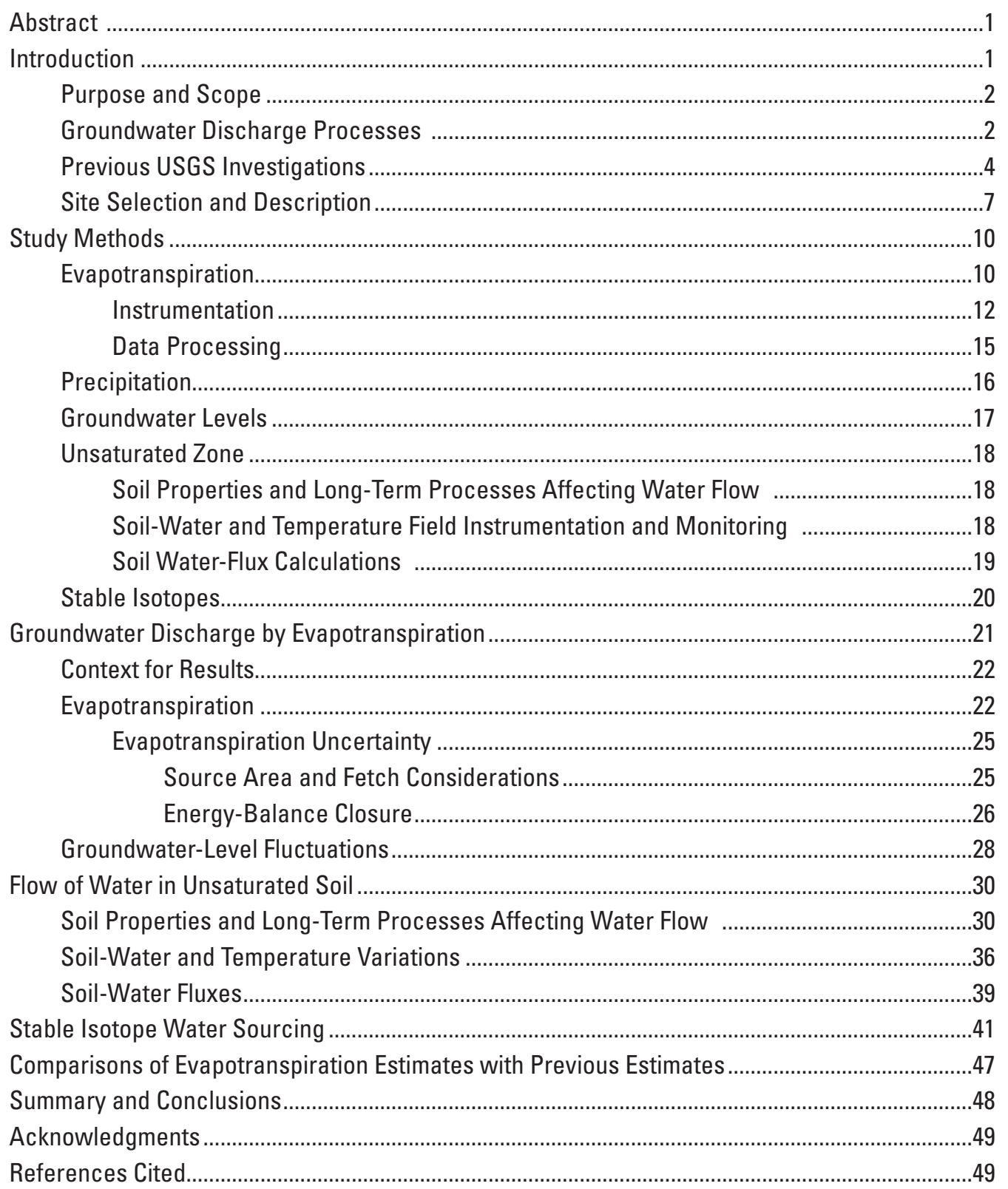




\section{Figures}

1. Map showing location of Amargosa Flat study area and Amargosa Desert Research Site, Amargosa Desert, Nye County, Nevada..

2. Conceptual diagrams showing spatial relations between saturated, capillary fringe, and unsaturated zones, and root distributions for arid land phreatophytes, and xerophytes.

3. Map showing location of Amargosa Flat study area, Ash Meadows National Wildlife Refuge, and evapotranspiration units classified by Laczniak and others (2001), Nye County, Nevada, and Inyo County, California

4. Map showing locations of evapotranspiration, unsaturated zone, and saturated zone monitoring sites, Amargosa Flat, Nye County, Nevada..

5. Photographs showing eddy-covariance station, vegetation, and surface soil at Amargosa Flat Shallow site Amargosa Flat Deep site, and Amargosa Desert Research Site, Amargosa Desert, Nye County, Nevada

6. Photographs and schematic diagrams showing evapotranspiration, unsaturated zone, and saturated zone measurements at monitoring sites Amargosa Flat Shallow, Intermediate, and Deep, Amargosa Desert, Nye County, Nevada.

7. Photographs showing eddy-covariance station and sensors, Amargosa Flat Deep site, Amargosa Desert, and eddy-covariance station intercomparison, Amargosa Desert Research Site, Nye County, Nevada..

8. Graphs showing daily total evapotranspiration and precipitation at Amargosa Desert Research Site and Amargosa Flat Shallow and Amargosa Flat Deep sites, Amargosa Desert, Nye County, Nevada, November 15, 2011, to November 14, 2013

9. Graph showing cumulative difference in daily total evapotranspiration measured at Amargosa Flat Shallow and Amargosa Flat Deep sites, Amargosa Desert, Nye County, Nevada, November 15, 2011, to November 14, 2013

10. Graph showing water-level depth and daily precipitation at Amargosa Flat Shallow and Amargosa Flat Deep sites, Amargosa Desert, Nye County, Nevada, November 15, 2011, to November 14, 2013.

11. Graph showing water-level depth and evapotranspiration, Amargosa Flat Shallow and Amargosa Flat Deep sites, Amargosa Desert, Nye County, Nevada, July 24-29, 2012

12. Graphs showing soil profile variations in particle-size distribution determined using cores collected at the beginning of the study for sand 0.05-2 millimeters, silt 0.002-0.05 millimeters, and clay less than 0.002 millimeters for the Amargosa Flat Shallow and Amargosa Flat Deep sites, Amargosa Desert, Nye County, Nevada, November 2011.

13. Graph showing soil profile variations in saturated hydraulic conductivity determined using cores collected at the beginning of the study at Amargosa Flat Shallow and Amargosa Flat Deep sites, Amargosa Desert, Nye County, Nevada, November 2011 


\section{Figures-Continued}

14. Graphs showing gravimetric soil-water retention data for selected depths from samples collected at the beginning of the study at Amargosa Flat Shallow and Amargosa Flat Deep sites, Amargosa Desert, Nye County, Nevada, November 2011.

15. Graphs showing volumetric soil-water retention data and calculated hydraulic-property functions for selected depths determined using cores collected at the beginning of the study at Amargosa Flat Shallow site: soil-water retention, and conductivity functions; and Amargosa Flat Deep site: soil-water retention, and conductivity functions, Amargosa Desert, Nye County, Nevada, November 2011

16. Graphs showing soil profiles of chloride, water potential, and water content determined using cores collected at the beginning of the study at Amargosa Flat Shallow and Amargosa Flat Deep sites, Amargosa Desert, Nye County, Nevada, November 2011 .

17. Graphs showing periodic mean soil-water content measurements with depth at each site for the full profile and upper 2 meters, respectively: at Amargosa Flat Shallow site, Amargosa Flat Deep site, and Amargosa Desert Research Site, Amargosa Desert, Nye County, Nevada, November 10, 2011, to November 12, 2013.

18. Graphs showing daily mean soil-water potential for Amargosa Flat Shallow and Amargosa Flat Deep and soil temperature measurements for selected depths at AFS and AFD sites, Amargosa Desert, Nye County, Nevada, November 17, 2011, to November 12, 2013.

19. Graphs showing daily total vertical-flux estimates for isothermal liquid, isothermal vapor, and thermal vapor at Amargosa Flat Shallow site and Amargosa Flat Deep site, Amargosa Desert, Nye County, Nevada, November 18, 2011, to November 8, 2013

20. Graphs showing stable-isotope compositions of oxygen and hydrogen for cumulative precipitation, soil water with depth below land surface, and groundwater sampled at the beginning of the study at Amargosa Flat Shallow, Amargosa Flat Intermediate, and Amargosa Flat Deep sites, Amargosa Desert, Nye County, Nevada, November 2011.

21. Graphs showing relations between stable-isotope compositions of oxygen and hydrogen for published global and local meteoric water lines, and for compositions of cumulative precipitation, groundwater, soil water, and plant water at Amargosa Flat Shallow site, Amargosa Flat Intermediate site, Amargosa Flat Deep site, and Amargosa Desert Research Site, July 2011-November 2012, and for ADRS groundwater, April 2013, Amargosa Desert, Nye County, Nevada.

22. Graph showing groundwater evapotranspiration (GWET) as a function of capillary-fringe and saturated-zone depths, Amargosa Flat Shallow and Amargosa Flat Deep sites, Amargosa Desert, Nye County, Nevada, November 15, 2011, to November 14, 2013. 


\section{Tables}

1. Previous estimates of groundwater discharge by evapotranspiration, Amargosa Desert, Nevada and California...

2. Locations and general descriptions of evapotranspiration, unsaturated zone, and saturated zone monitoring sites, Amargosa Desert, Nye County, Nevada

3. Instruments used to measure evapotranspiration, energy balance, and precipitation at eddy-covariance evapotranspiration sites, Amargosa Desert, Nye County, Nevada.

4. Eddy-covariance sensor intercomparison statistics, Amargosa Desert Research Site, Nye County, Nevada, July 9-25, 2011

5. Radiometer intercomparison statistics, Amargosa Desert Research Site, Nye County, Nevada, July 19-26, 2011

6. Mean-annual measured and corrected precipitation, Amargosa Desert, Nye County, Nevada, November 15, 2011, to November 14, 2013

7. General description of saturated zone monitoring sites, Amargosa Flat, Nye County, Nevada 17

8. Stable isotope samples of oxygen and hydrogen collected at study sites, Amargosa Desert, Nye County, Nevada, 2011-13.

9. Mean annual total evapotranspiration, precipitation, and groundwater evapotranspiration, and uncertainties for each variable, Amargosa Desert, Nye County, Nevada, November 15, 2011, to November 14, 2013.

10. Source area of turbulent-flux measurements at eddy-covariance stations, Amargosa Desert, Nye County, Nevada, November 15, 2011, to November 14, 2013 ....26

11. Mean daily energy-balance data, Amargosa Desert, Nye County, Nevada, November 15, 2011, to November 14, 2013

12. Mean stable-isotope compositions of oxygen for honey mesquite-stem water sampled in a wash near the study sites and groundwater and cumulative precipitation from the study sites, Amargosa Flat, Nye County, Nevada, July 2011-August 2012 


\section{Conversion Factors}

Inch/Pound to International System of Units

\begin{tabular}{lcc}
\hline Multiply & By & To obtain \\
\hline acre & Area & \\
\hline & 4,047 & square meter $\left(\mathrm{m}^{2}\right)$ \\
\hline foot per year $(\mathrm{ft} / \mathrm{yr})$ & Flow rate & \\
\hline
\end{tabular}

International System of Units to Inch/Pound

\begin{tabular}{|c|c|c|}
\hline Multiply & By & To obtain \\
\hline \multicolumn{3}{|c|}{ Length } \\
\hline centimeter (cm) & 0.3937 & inch (in.) \\
\hline millimeter (mm) & 0.03937 & inch (in.) \\
\hline meter (m) & 3.281 & foot (ft) \\
\hline kilometer (km) & 0.6214 & mile (mi) \\
\hline \multicolumn{3}{|c|}{ Area } \\
\hline square meter $\left(\mathrm{m}^{2}\right)$ & 0.0002471 & acre \\
\hline square kilometer $\left(\mathrm{km}^{2}\right)$ & 247.1044 & acre \\
\hline \multicolumn{3}{|c|}{ Volume } \\
\hline cubic centimeter $\left(\mathrm{cm}^{3}\right)$ & 0.06102 & cubic inch $\left(\right.$ in $\left.^{3}\right)$ \\
\hline cubic meter $\left(\mathrm{m}^{3}\right)$ & 0.0002642 & million gallons (Mgal) \\
\hline cubic meter $\left(\mathrm{m}^{3}\right)$ & 0.0008107 & acre-foot (acre-ft) \\
\hline milliliter (mL) & 0.03381 & ounce (oz) \\
\hline million cubic meter $\left(\mathrm{Mm}^{3}\right)$ & 0.8107132 & thousand acre-foot (Kaf) \\
\hline \multicolumn{3}{|c|}{ Flow rate } \\
\hline centimeter per second $(\mathrm{cm} / \mathrm{s})$ & 0.02237 & miles per hour (mi/h) \\
\hline meter per second $(\mathrm{m} / \mathrm{s})$ & 2.2369 & miles per hour (mi/h) \\
\hline meter per year (m/yr) & 3.281 & foot per year ft/yr) \\
\hline millimeter per day (mm/d) & 0.03937 & inch per day (in/d) \\
\hline millimeter per year (mm/yr) & 0.03937 & inch per year (in/yr) \\
\hline \multicolumn{3}{|c|}{ Mass } \\
\hline milligram (mg) & 0.00003527 & ounce, avoirdupois (oz) \\
\hline gram (g) & 0.03527 & ounce, avoirdupois (oz) \\
\hline kilogram (kg) & 2.205 & pound, avoirdupois (lb) \\
\hline \multicolumn{3}{|c|}{ Pressure } \\
\hline megapascal (MPa) & 145.0377 & pound per square inch $\left(\mathrm{lb} / \mathrm{in}^{2}\right)$ \\
\hline \multicolumn{3}{|c|}{ Density } \\
\hline gram per cubic meter $\left(\mathrm{g} / \mathrm{m}^{3}\right)$ & 0.00006242 & pound per cubic foot $\left(\mathrm{lb} / \mathrm{ft}^{3}\right)$ \\
\hline \multicolumn{3}{|c|}{ Energy } \\
\hline $\begin{array}{l}\text { watt per square meter } \\
\qquad\left(\mathrm{W} / \mathrm{m}^{2}\right)\end{array}$ & 0.0222 & $\begin{array}{l}\text { calorie per second per square foot } \\
{\left[(\mathrm{cal} / \mathrm{s}) / \mathrm{ft}^{2}\right]}\end{array}$ \\
\hline joule (J) & 0.2390 & calorie (cal) \\
\hline
\end{tabular}

Temperature in degrees Celsius $\left({ }^{\circ} \mathrm{C}\right)$ may be converted to degrees Fahrenheit $\left({ }^{\circ} \mathrm{F}\right)$ as follows:

$$
{ }^{\circ} \mathrm{F}=\left(1.8 \times{ }^{\circ} \mathrm{C}\right)+32 .
$$




\section{Datums}

Vertical coordinate information is referenced to North American Vertical Datum of 1988 (NAVD 88).

Horizontal coordinate information is referenced to North American Datum of 1983 (NAD 83).

Elevation, as used in this report, refers to distance above the vertical datum.

\section{Abbreviations}

$\begin{array}{ll}\text { ADRS } & \text { Amargosa Desert Research Site } \\ \text { AFD } & \text { Amargosa Flat Deep site } \\ \text { AFI } & \text { Amargosa Flat Intermediate site } \\ \text { AFS } & \text { Amargosa Flat Shallow site } \\ \text { bls } & \text { below land surface } \\ \text { CNR1 } & \text { four-component radiometer } \\ \text { CNR2 } & \text { two-component net radiometer } \\ \text { CS616 } & \text { soil-moisture probe } \\ \text { CSAT3 } & \text { three-dimensional sonic anemometer } \\ \text { CV } & \text { coefficient of variation } \\ \text { EBR } & \text { energy-balance ratio } \\ \text { ET } & \text { evapotranspiration } \\ \text { GMWL } & \text { global meteoric water line } \\ \text { GWET } & \text { groundwater discharge by evapotranspiration } \\ \text { HFP01 } & \text { soil-heat flux plate } \\ \text { Hz } & \text { Hertz } \\ \text { KH20 } & \text { krypton hygrometer } \\ \text { LMWL } & \text { local meteoric water line } \\ \text { SSURG0 } & \text { Soil Survey Geographic database } \\ \text { TCAV } & \text { soil-temperature thermocouple } \\ \text { USGS } & \text { U.S. Geological Survey }\end{array}$




\title{
Groundwater Discharge by Evapotranspiration, Flow of Water in Unsaturated Soil, and Stable Isotope Water Sourcing in Areas of Sparse Vegetation, Amargosa Desert, Nye County, Nevada
}

\author{
By Michael T. Moreo, Brian J. Andraski, and C. Amanda Garcia
}

\section{Abstract}

This report documents methodology and results of a study to evaluate groundwater discharge by evapotranspiration (GWET) in sparsely vegetated areas of Amargosa Desert and improve understanding of hydrologic-continuum processes controlling groundwater discharge. Evapotranspiration and GWET rates were computed and characterized at three sites over 2 years using a combination of micrometeorological, unsaturated zone, and stable-isotope measurements. One site (Amargosa Flat Shallow [AFS]) was in a sparse and isolated area of saltgrass (Distichlis spicata) where the depth to groundwater was 3.8 meters $(\mathrm{m})$. The second site (Amargosa Flat Deep [AFD]) was in a sparse cover of predominantly shadscale (Atriplex confertifolia) where the depth to groundwater was $5.3 \mathrm{~m}$. The third site (Amargosa Desert Research Site [ADRS]), selected as a control site where GWET is assumed to be zero, was located in sparse vegetation dominated by creosote bush (Larrea tridentata) where the depth to groundwater was $110 \mathrm{~m}$.

Results indicated that capillary rise brought groundwater to within $0.9 \mathrm{~m}$ (at AFS) and $3 \mathrm{~m}$ (at AFD) of land surface, and that GWET rates were largely controlled by the slow but relatively persistent upward flow of water through the unsaturated zone in response to atmospheric-evaporative demands. Greater GWET at AFS (50 \pm 20 millimeters per year $[\mathrm{mm} / \mathrm{yr}])$ than at AFD $(16 \pm 15 \mathrm{~mm} / \mathrm{yr})$ corresponded with its shallower depth to the capillary fringe and constantly higher soil-water content. The stable-isotope dataset for hydrogen $\left(\delta^{2} \mathrm{H}\right)$ and oxygen $\left(\delta^{18} \mathrm{O}\right)$ illustrated a broad range of plantwater-uptake scenarios. The AFS saltgrass and AFD shadscale responded to changing environmental conditions and their opportunistic water use included the time- and depth-variable uptake of unsaturated-zone water derived from a combination of groundwater and precipitation. These results can be used to estimate GWET in other areas of Amargosa Desert where hydrologic conditions are similar.

\section{Introduction}

The Nevada Office of the State Engineer (State Engineer) has for many years relied upon U.S. Geological Survey (USGS) perennial yield estimates to manage limited groundwater resources in Nevada (Office of the State Engineer, 2007). The perennial yield of any given basin is determined from groundwater-budget estimates. Of the three main components of a groundwater budget-natural discharge, recharge, and subsurface flow-estimating natural groundwater discharge is the most pragmatic (Bredehoeft, 2007). Unlike recharge and subsurface flow components of the water budget, natural groundwater discharge can be estimated directly from measurements made within groundwater discharge areas. Reliable estimates of groundwater discharge then can be used to constrain other, more-difficult-to-quantify components of the water budget.

The quantity of groundwater discharging from Amargosa Desert has been estimated by previous USGS studies (Walker and Eakin, 1963; Laczniak and others, 1999, 2001). These studies have estimated discharge by measuring spring flow, evaporation, and evapotranspiration from putative areas of groundwater discharge. Discharge areas in southern Nevada traditionally have been characterized by the presence of phreatophytes situated near major springs, seeps, and playas. Areas outside of traditional discharge areas, which typically are occupied by xerophytes, were assumed to contribute negligibly to groundwater discharge. Laczniak and others (1999, p. 14) described these xeric areas as “....areas of no substantial ground-water ET."

Based on internal studies, however, Nye County contended in a hearing before the State Engineer that groundwater discharge occurs from sparsely vegetated areas outside of traditional groundwater discharge areas, wherever the depth to groundwater is less than 15 meters (m) (Office of the State Engineer, 2007). These areas, as mapped by Nye County, consist of 230 square kilometers $\left(\mathrm{km}^{2}\right)$ where depth 
to the water table or potentiometric surface is less than $3 \mathrm{~m}$, and $180 \mathrm{~km}^{2}$ where depth to the water table or potentiometric surface ranges from 3 to $15 \mathrm{~m}$. The annual groundwater discharge rate estimated by Nye County for each respective area is 150 millimeters $(\mathrm{mm})$ and $30 \mathrm{~mm}$. Based on these estimates, Nye County posited that 41.3 million cubic meters $\left(\mathrm{Mm}^{3} ; 33.5\right.$ thousand acre-feet [Kaf]) of annual groundwater discharge was not accounted by previous USGS studies, and argued that the State Engineer should revise the perennial yield estimate by Walker and Eakin (1963) upward of more than 100 percent, from $30 \mathrm{Mm}^{3}$ (24 Kaf) to $62 \mathrm{Mm}^{3}$ (50 Kaf). The committed groundwater resources in Amargosa Desert is $76 \mathrm{Mm}^{3}$ (62 Kaf) (Office of the State Engineer, 2007).

In cooperation with Nye County and the U.S. Department of Energy, the USGS implemented a study to further evaluate the potential for groundwater discharge from sparsely vegetated areas in the Amargosa Desert. A study area near Amargosa Flat (fig. 1) was selected and instrumented to measure groundwater-discharge rates and investigate groundwater-discharge processes where the depth to groundwater is less than $15 \mathrm{~m}$. This study area was previously classified as having (1) no substantial groundwater loss (Laczniak and others, 1999, 2001) and (2) a groundwater discharge rate of 150 millimeters per year (mm/yr) (T.S. Buqo, Nye County, written commun., 2006; Office of the State Engineer, 2007). The USGS Amargosa Desert Research Site (ADRS) was selected as the dry end-member "control site" for the study. Regional groundwater discharge at ADRS is assumed $=0 \mathrm{~mm} / \mathrm{yr}$ because the thick unsaturated zone (110 $\mathrm{m}$ ) inhibits the upward movement of groundwater from the saturated zone to land surface (Walvoord and others, 2004).

\section{Purpose and Scope}

This report documents methodology and results of a groundwater discharge investigation in sparsely vegetated areas of Amargosa Desert. The study objectives were to: (1) compute groundwater discharge based on evapotranspiration and precipitation measurements at instrumented sites, and (2) improve understanding of hydrologic-continuum processes controlling groundwater discharge through analysis of complementary saturated zone, unsaturated zone, and plant measurements. The measurement period was from November 2011 to November 2013. A more thorough understanding of groundwater discharge and the factors controlling groundwater movement through the unsaturated zone was gained from this research effort, and the results can be used to guide future studies of groundwater discharge in areas of sparse vegetation. All pertinent data are available in Moreo and others (2017).

\section{Groundwater Discharge Processes}

Conceptual diagrams of two desert-plant types that are distinguished by their occurrence in relation to the saturated and unsaturated zones are shown in figure 2. Phreatophytes rely on consistently available groundwater for their existence in the desert Southwest. The Greek roots of the word phreatophyte are "well plant," meaning that these plants behave like natural wells accessing groundwater from the saturated zone or the overlying capillary fringe (Meinzer, 1927). In contrast, xerophytes (from Greek roots meaning “dry plants") are classified as being reliant on incident precipitation and able to survive for long periods between precipitation events (Robinson, 1958).

Below the top of the saturated zone, all the interstices or pores are completely filled with water that is under greater than atmospheric (positive) pressure. The capillary fringe is that part of the unsaturated zone, immediately above the saturated zone, where some or all of the pores are filled with water that is under less than atmospheric (negative) pressure (Lohman and others, 1972). Capillary forces in the fringe exert a tension or pull that draws groundwater upward from the saturated zone until a state of equilibrium is reached. The height of the capillary fringe is dependent on the pore size and may range from less than $0.01 \mathrm{~m}$ in gravel to $3.0 \mathrm{~m}$ in clay (Fetter, 1980). Capillary-fringe water is able to resist the downward pull of gravity, but it can be withdrawn by plant roots and, if the fringe extends to near the surface, it also can be lost by bare-soil evaporation. Evapotranspirational losses of water, in turn establish an upward-directed water potential gradient whereby water removed from the capillary fringe is replaced by groundwater rising from the saturated zone by capillary action (White, 1932; Gardner, 1958). The rate of capillary rise controls the movement of water from the saturated zone into the unsaturated zone and depends on many factors including atmospheric conditions, soil properties, and soil moisture conditions (Laczniak and others, 1999).

Groundwater discharges naturally in topographically low areas of basins where groundwater is at or near land surface primarily by spring flow and seepage, transpiration by local phreatophytes, and evaporation from soil and open-water surfaces. A number of recent investigations have applied various remote-sensing techniques using satellite imagery in combination with field mapping and micrometeorological measurements to identify and group areas with similar phreatophytes and soil conditions (Laczniak and others, 1999, 2001, 2006, 2007; Reiner and others, 2002; DeMeo and others, 2003; Moreo and others, 2007; Allander and others, 2009; Garcia and others, 2014; Berger and others, 2016). These phreatophyte and soil groupings are referred to as evapotranspiration units because they represent areas with similar evapotranspiration rates. Typical evapotranspiration 


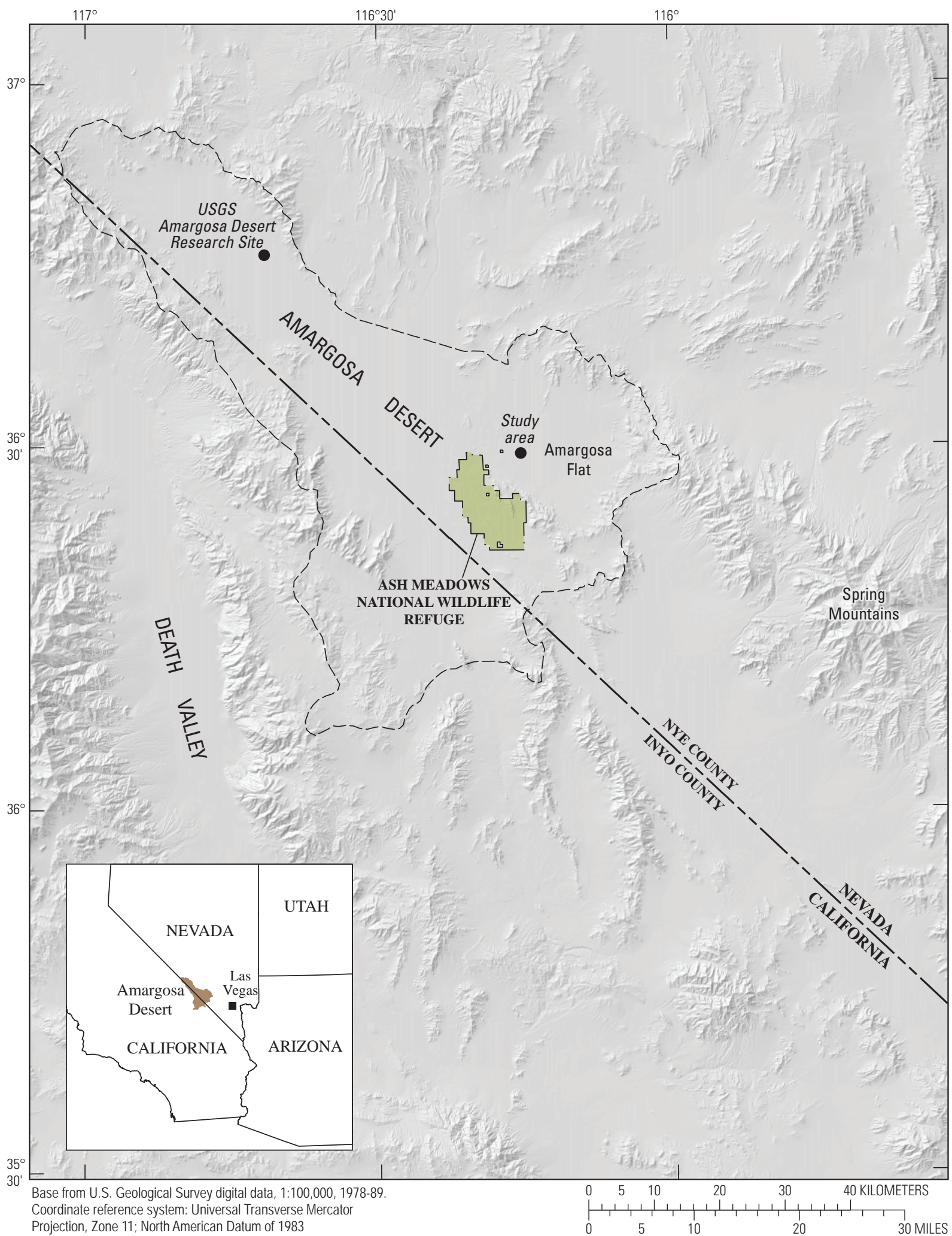

Figure 1. Location of Amargosa Flat study area and Amargosa Desert Research Site, Amargosa Desert, Nye County, Nevada. 


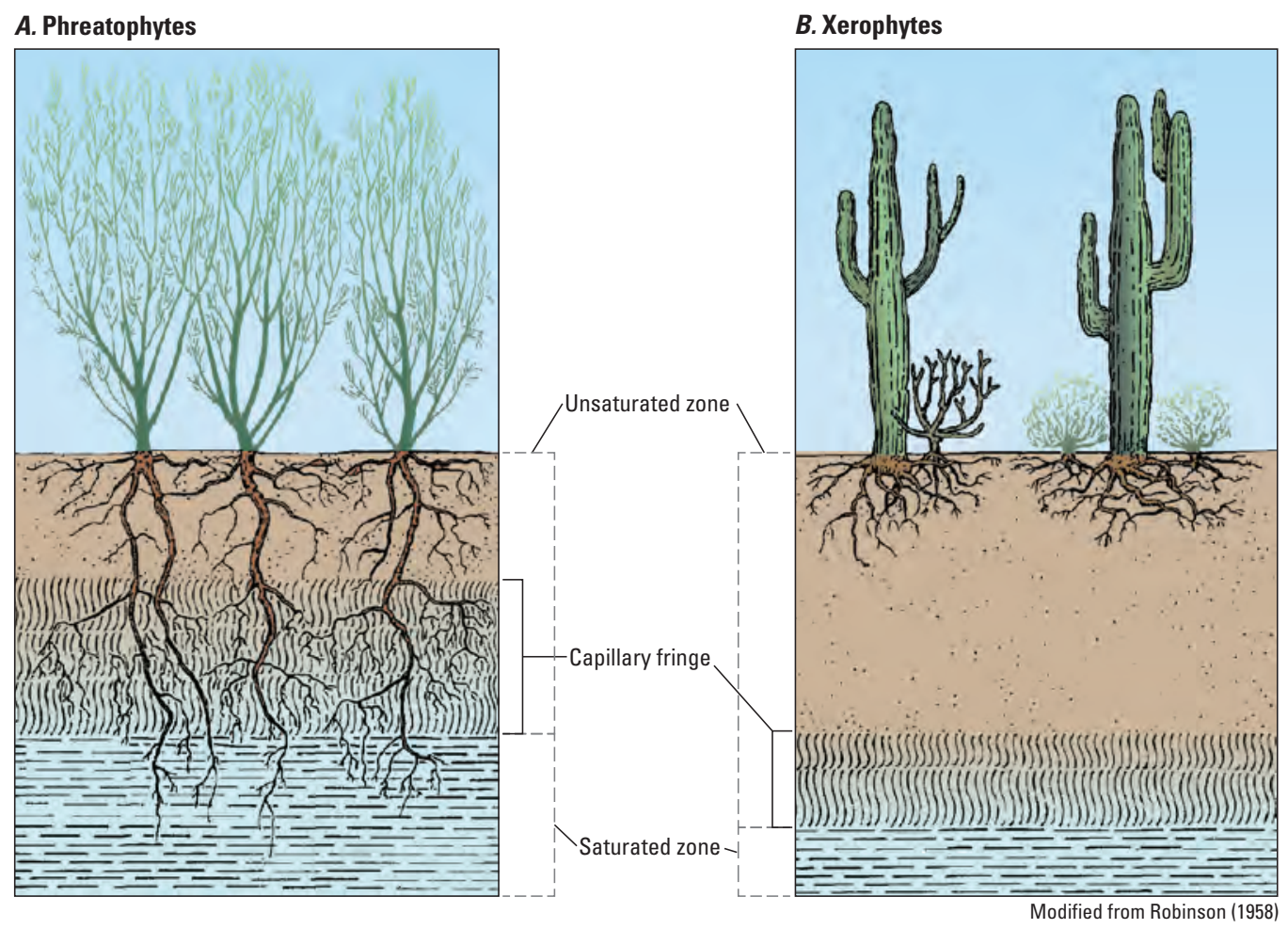

Figure 2. Spatial relations between saturated, capillary fringe, and unsaturated zones, and root distributions for arid land $(A)$ phreatophytes, and $(B)$ xerophytes. units include (1) areas of no vegetation, such as open water, dry playa, and moist bare soil; and (2) areas with vegetation dominated by phreatophytic trees, shrubs, grasses, rushes, and reeds. Total evapotranspiration equals the volume of water lost to the atmosphere in the discharge area, and it is computed by summing the water volume for each evapotranspiration unit (the product of the evapotranspiration rate and its area). Groundwater discharge by evapotranspiration is then estimated by subtracting non-groundwater contributions such as local precipitation from total evapotranspiration. In this report (1) evapotranspiration (ET) refers to the combined processes of evaporation and transpiration from areas with vegetation, (2) total ET refers to evapotranspiration from all water sources (precipitation, groundwater), and (3) groundwater discharge by evapotranspiration (GWET) refers to groundwater evaporation from areas with no vegetation and groundwater evapotranspiration from areas with vegetation.

\section{Previous USGS Investigations}

During the 1960s and 1970s, the USGS in cooperation with the State of Nevada completed a series of reconnaissance studies to evaluate the groundwater resources of Nevada. The results of these studies were published in a series of reports describing preliminary water-resources estimates. The reconnaissance report for the Amargosa Desert (Walker and Eakin, 1963) estimated GWET as follows: $49 \mathrm{~km}^{2}$ of bare soil with a GWET rate of 0.3 meter per year $(\mathrm{m} / \mathrm{yr}) ; 8 \mathrm{~km}^{2}$ of vegetation with a GWET rate of $0.15 \mathrm{~m} / \mathrm{yr}$; and $17 \mathrm{~km}^{2}$ of vegetation with a GWET rate of $0.9 \mathrm{~m} / \mathrm{yr}$. However, the method for delineating the areal distribution of bare ground and vegetation was not described or mapped, and the applied GWET rates were approximated from work done in other areas. Walker and Eakin (1963, p. 21-23) described their estimate of average annual GWET (30 $\mathrm{Mm}^{3}$ [24 Kaf]) as “crude.” This estimate included $0.6 \mathrm{Mm}^{3}$ (0.5 Kaf) of subsurface outflow along the Amargosa River channel to the south.

As part of a larger effort to evaluate the risk of contaminant migration from areas of nuclear testing in southern Nevada, the USGS entered into a cooperative agreement with the U.S. Department of Energy in 1993 to improve the accuracy and reduce the uncertainty in existing GWET estimates. The Ash Meadows National Wildlife Refuge (hereinafter referred to as Ash Meadows) was the first discharge area selected for study (Laczniak and others, 1999). Ten representative sites were instrumented to measure the micrometeorological parameters required to solve the energy budget by the Bowen-ratio method and estimate GWET. Data were acquired at each site for a minimum of 1 year between 1993 and 1997. Seven unique ET units were defined and classified on the basis of spectral-reflectance characteristics. Annual GWET for Ash Meadows was computed by summing GWET computed for each of the seven classified ET units. For the second study, GWET rates measured at Ash Meadows were extrapolated using remote-sensing techniques to estimate GWET in areas outside of Ash Meadows (Laczniak and others, 2001). Ten ET units were delineated (fig. 3). 


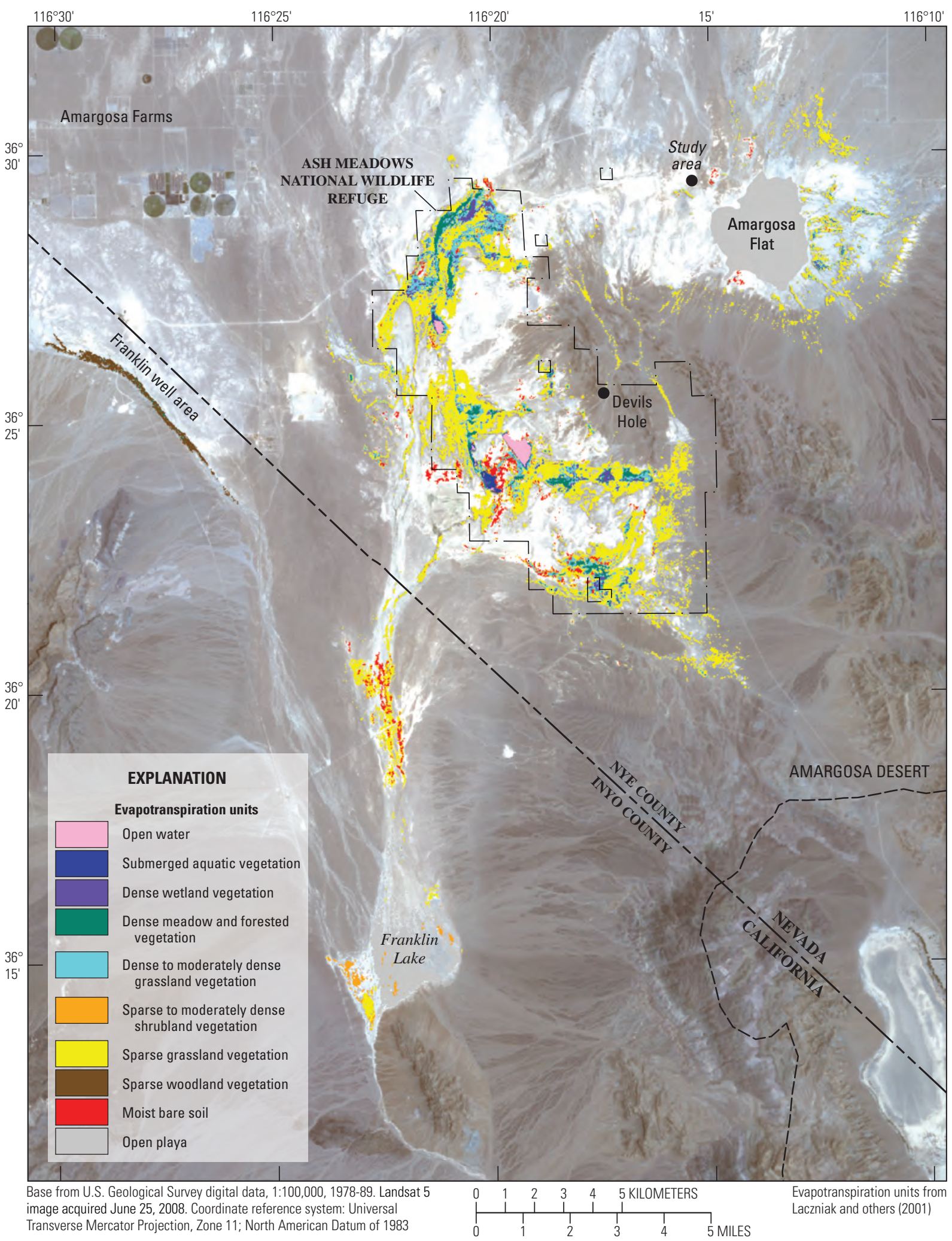

Figure 3. Location of Amargosa Flat study area, Ash Meadows National Wildlife Refuge, and evapotranspiration units classified by Laczniak and others (2001), Nye County, Nevada, and Inyo County, California. 
The total GWET estimate for Amargosa Desert (23.87 $\mathrm{Mm}^{3}$ [19.35 Kaf]) was computed by summing GWET from Ash Meadows, Nevada (22 Mm³ $^{3}$ 18 Kaf]), Franklin Lake, California (1.2 $\mathrm{Mm}^{3}$ [1.0 Kaf]), and Franklin well area, California (0.43 $\mathrm{Mm}^{3}$ [0.35 Kaf]) discharge areas. Consistent with previous GWET estimates by the USGS in Nevada, areas with xeric vegetation were considered to have no substantial groundwater loss; however, Laczniak and others (1999, p. 49) added the following caveat when describing limitations associated with the unclassified xeric area:

"The remaining part of Ash Meadows, comprising nearly 40,000 acres, is assumed to be an area of no substantial ground-water loss. This assumption, although strongly supported by the lack of vegetation, dryness of soil, and greater depths to the water table (generally exceeding $15 \mathrm{ft}$ ), could result in some error in the estimate of groundwater discharge. Even though ET rates are likely to be small, volumetric losses could be substantial considering the extensive size of area."

Although the possibility of small GWET rates in xeric areas with shallow groundwater has been acknowledged, developing reliable estimates for these areas was considered impractical.

To facilitate comparisons between the previous work by Walker and Eakin (1963) and Laczniak and others (1999, 2001), the land areas and GWET estimates reported by each study were grouped into two categories - vegetation and bare soil (table 1). Laczniak and others (2001) delineated seven ET units for different types of phreatophytic vegetation accounting for $44.9 \mathrm{~km}^{2}$ (11,100 acres) with an area-weightedaverage GWET rate of 509 mm/yr (1.67 ft/yr) and an annual GWET volume of $22.80 \mathrm{Mm}^{3}$ (18.50 Kaf). Two ET units were delineated to represent bare soil accounting for $16.19 \mathrm{~km}^{2}$ (4,000 acres) with an area-weighted average GWET rate of $64 \mathrm{~mm} / \mathrm{yr}(0.21 \mathrm{ft} / \mathrm{yr})$ and an annual GWET volume of 1.0 $\mathrm{Mm}^{3}$ (0.85 Kaf). The areas of Franklin Lake playa and Amargosa Flat playa accounted for about 93 percent of the bare soil area delineated by Laczniak and others (2001). Laczniak and others (2001) estimated almost twice the area of phreatophytic vegetation, and only one-third the area of bare soil, as Walker and Eakin (1963). The GWET rate assigned to bare soil by Walker and Eakin (1963) was almost 5 times greater than the area-weighted average rate assigned by Laczniak and others (2001). As a result, total GWET estimated for Amargosa Desert by Walker and Eakin (1963) was about 22 percent greater than the estimate by Laczniak and others (2001). The detailed field investigations by Laczniak and others $(1999,2001)$ and their documentation of micrometeorological measurements, computed GWET rates, and ET unit delineations provided the U.S. Department of Energy with estimates that were more accurate and less uncertain than previous estimates. These estimates are critical to the defensibility of ongoing efforts to model groundwater flow and transport processes.

Table 1. Previous estimates of groundwater discharge by evapotranspiration (GWET), Amargosa Desert, Nevada and California.

[Estimates are presented in reported units. All vegetation and bare soil estimates for each study are grouped for brevity and comparison between studies. Abbreviations: ft/yr, foot per year; Kaf/yr, thousand acre-feet per year]

\begin{tabular}{|c|c|c|c|c|c|}
\hline Study & Group & $\begin{array}{c}\text { Area } \\
\text { (acres) }\end{array}$ & $\begin{array}{c}\text { Area-weighted } \\
\text { average GWET rate } \\
\text { (ft/yr) }\end{array}$ & $\begin{array}{c}\text { Component } \\
\text { GWET } \\
\text { (Kaf/yr) }\end{array}$ & $\begin{array}{l}\text { Total } \\
\text { GWET } \\
\text { (Kaf/yr) }\end{array}$ \\
\hline \multirow{2}{*}{$\begin{array}{l}\text { Walker and Eakin } \\
\text { (1963) }\end{array}$} & Vegetation & 6,200 & 1.85 & 11.50 & \multirow[t]{2}{*}{23.50} \\
\hline & Bare soil & 12,000 & 1.00 & 12.00 & \\
\hline \multirow{2}{*}{$\begin{array}{l}\text { Laczniak and } \\
\text { others (2001) }\end{array}$} & Vegetation & 11,100 & 1.67 & 18.50 & \multirow[t]{2}{*}{19.35} \\
\hline & Bare soil & 4,000 & 0.21 & 0.85 & \\
\hline
\end{tabular}




\section{Site Selection and Description}

A study area northwest of Amargosa Flat playa was selected with concurrence from Nye County to investigate and quantify GWET processes and rates (figs. 1 and 3). The study area was selected, in part, to be within the area where the estimated GWET was $150 \mathrm{~mm} / \mathrm{yr}$ (T.S. Buqo, Nye County, written commun., 2006). Two sites (AFS and AFD) were instrumented for continuous measurements of evapotranspiration, precipitation, soil-water potential, and groundwater levels. A third site (AFI) was selected for various periodic measurements including groundwater levels (fig. 4). Site selection was based on several criteria: (1) a location within the area defined by Nye County as having a depth to the water table or potentiometric surface of less than $3 \mathrm{~m}$, (2) within a sparsely vegetated area, (3) outside of environmentally protected areas, (4) adequate access that included obtainable permissions for a drill rig, and (5) adequate fetch (see section, "Source Area and Fetch
Considerations") to accurately measure evapotranspiration within the desired setting and sufficiently distant from undesired water sources that might "contaminate" the measurements (for example, localized groundwater discharge areas, ephemeral drainages). The surficial lithology of the Amargosa Flat area consists of widespread deposits of finegrained sedimentary rocks that correspond well with mapped paleogroundwater discharge deposits and well-developed playa and palustrine deposits (Taylor and Sweetkind, 2014). Surface soils are mapped as the Casaga-Nowoy complex, 2-4 percent slopes (fine-loamy, mixed, superactive, thermic Typic Natrargrids) and characterized as Aridisols in the Soil Survey Geographic (SSURGO) database (Soil Survey Staff, Natural Resources Conservation Service, 2014).

The AFS site was established in the North American Warm Desert Playa ecological system (Prior-Magee and others, 2007) in an area with a sparse cover of saltgrass (Distichlis spicata (L.) Greene (Poaceae)) at an elevation of about 708 m on July 26, 2011 (figs. 4 and 5A; table 2).

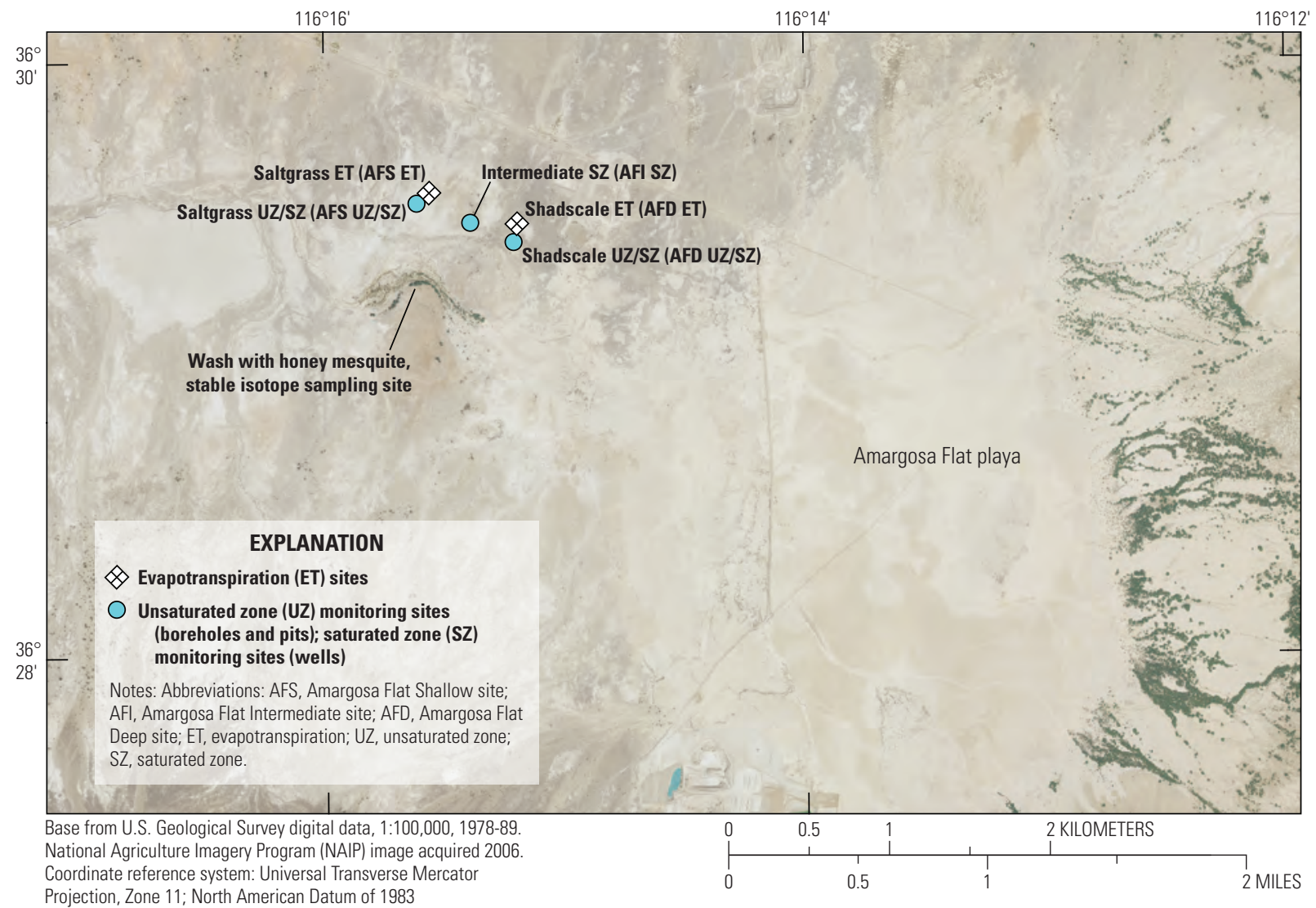

Figure 4. Locations of evapotranspiration, unsaturated zone (boreholes and pits), and saturated zone (wells) monitoring sites, Amargosa Flat, Nye County, Nevada. 



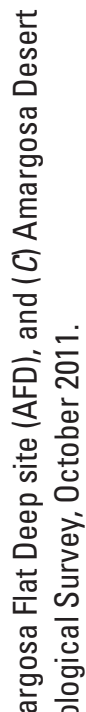
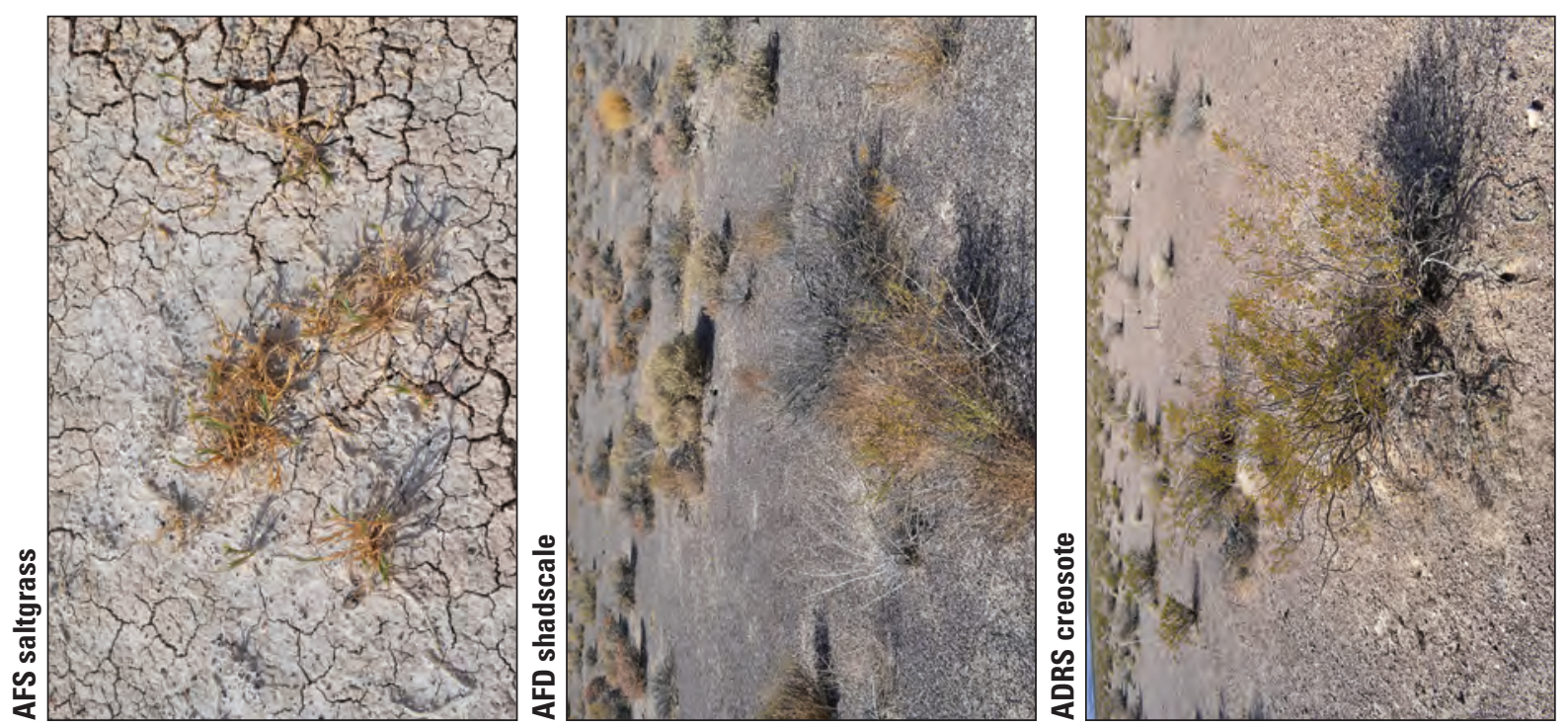

选 峞

包

崖

$\stackrel{0}{ \pm} \sum_{1}^{\infty}$

高

क

훈 즈

๙ึ. ప్

음

苋告

ভ흔

흠 음

क

苋
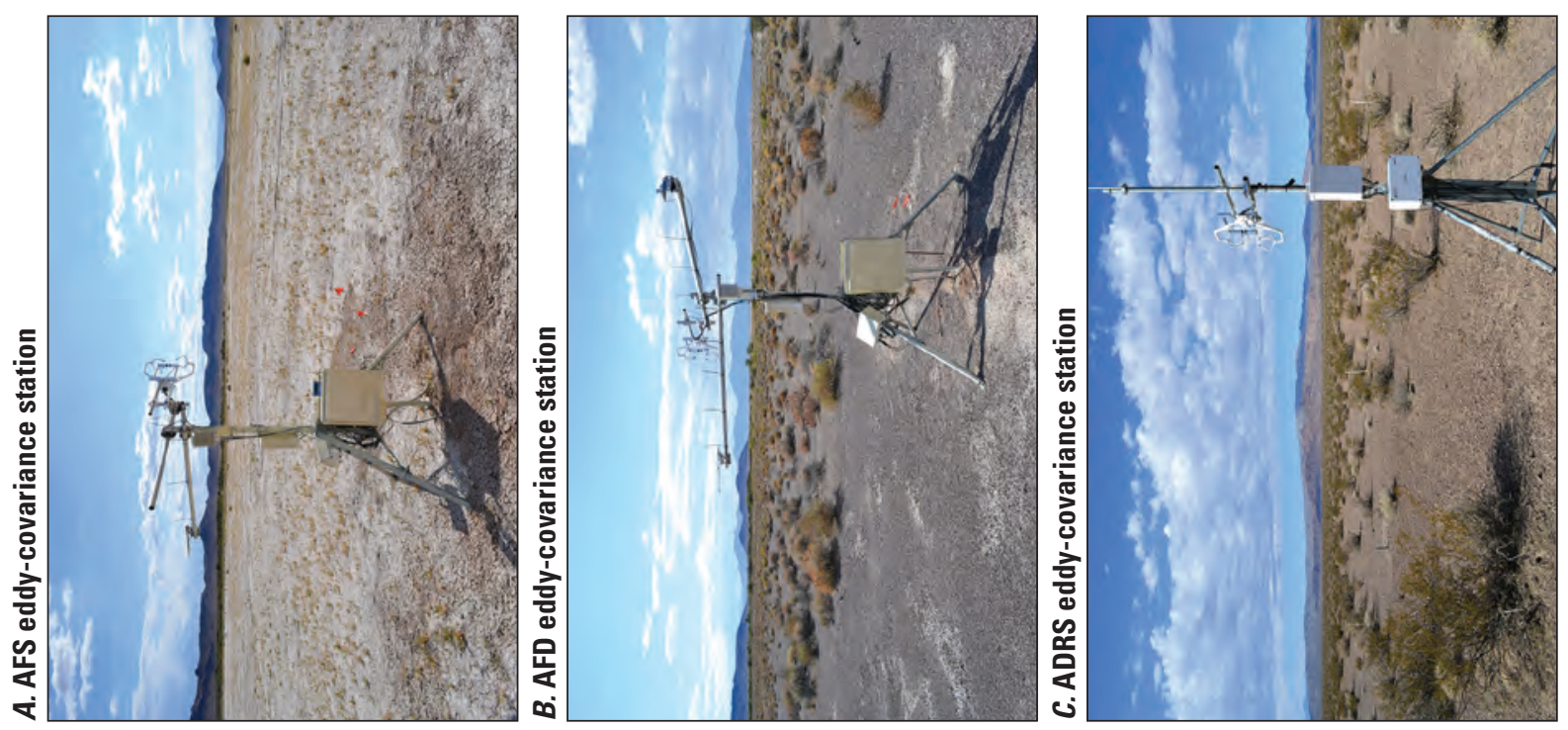

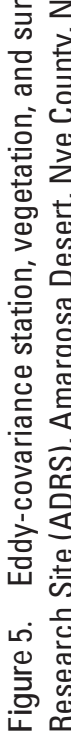


Table 2. Locations and general descriptions of evapotranspiration, unsaturated zone, and saturated zone monitoring sites, Amargosa Desert, Nye County, Nevada.

[Site locations are shown in figures 1, 3, and 4. Elevations are in meters above North American Vertical Datum of 1988. Site name: AFS, Amargosa Flat Shallow site; AFI, Amargosa Flat Intermediate site; AFD, Amargosa Flat Deep site; ADRS, Amargosa Desert Research Site. ET, evapotranspiration; UZ, unsaturated zone; SZ, saturated zone. U.S. G eological Survey site identification: Unique identification number for site as stored in files and data bases of the U.S. Geological Survey]

\begin{tabular}{lcccccc}
\hline Site name & $\begin{array}{c}\text { U.S. Geological } \\
\text { Survey site } \\
\text { identification }\end{array}$ & $\begin{array}{c}\text { Latitude } \\
\text { (decimal } \\
\text { degrees) }\end{array}$ & $\begin{array}{c}\text { Longitude } \\
\text { (decimal } \\
\text { degrees) }\end{array}$ & $\begin{array}{c}\text { Elevation } \\
\text { (meters) }\end{array}$ & $\begin{array}{c}\text { Period of } \\
\text { operation }\end{array}$ & $\begin{array}{c}\text { Period of reported } \\
\text { measurements }\end{array}$ \\
\hline AFS ET & 362934116153401 & 36.4926 & -116.2594 & 708 & $07-26-11$ to $12-09-13$ & $11-15-11$ to 11-14-13 \\
AFD ET & 362927116151201 & 36.4909 & -116.2533 & 709 & $07-27-11$ to 12-09-13 & $11-15-11$ to 11-14-13 \\
ADRS ET & 364555117412401 & 36.7653 & -116.6933 & 845 & $07-26-11$ to 12-09-13 & $11-15-11$ to 11-14-13 \\
AFS UZ & 362931116153602 & 36.4921 & -116.2603 & 708 & $11-11-11$ to 12-09-13 & $11-15-11$ to 11-14-13 \\
AFD UZ & 362924116151302 & 36.4899 & -116.2535 & 709 & $11-10-11$ to 12-09-13 & $11-15-11$ to 11-14-13 \\
AFS SZ & 362931116153601 & 36.4921 & -116.2603 & 708 & $11-15-11$ to 12-09-13 & $11-16-11$ to 12-09-13 \\
AFI SZ & 362927116152401 & 36.4910 & -116.2565 & 709 & $11-15-11$ to 12-09-13 & $11-15-11$ to 12-09-13 \\
AFD SZ & 362924116151301 & 36.4899 & -116.2535 & 709 & $11-15-11$ to 12-09-13 & $11-15-11$ to 12-09-13 \\
\hline
\end{tabular}

Saltgrass is considered a phreatophyte when it occurs in groundwater discharge areas (Robinson, 1958). It is a shallowrooted perennial herb often found in saline soils where the depth to water has been observed to range between less than 0.3 and $4 \mathrm{~m}$ (Lee, 1912; Blaney and others, 1933; Robinson, 1958). It is a halophyte that is classified as a salt excreter because it has glandular cells that accumulate and then excrete salt through the cuticle that covers the leaf surface (Hauser, 2006). Plants consist of underground horizontal stems (rhizomes) that send out roots and vertical stems that generally branch near the surface into leafy aboveground shoots (ramets) 10-20 cm tall (Alpert, 1990). As a clonal plant, saltgrass can share resources among ramets by expanding into habitats more suitable for growth and transporting water to ramets experiencing physical stress (Hauser, 2006). Roots have tissue with an empty cavity, which is continuous with the empty cavity tissue in the rhizomes and leaf sheath, and provides an aerenchymatous network that allows for gas exchange and growth in heavy clay soils and (or) water-logged conditions (Hauser, 2006). As shown in figure 5A, the saltgrass at AFS usually appeared stressed (dry and yellowish) and the soil surface had a characteristic salt crust that often was dry and cracked. The depth to groundwater in the monitoring well shortly after completion (1.72 $\mathrm{m}$ below land surface [bls]) was higher than the first occurrence of groundwater during drilling ( $3.8 \mathrm{~m}$ bls) indicating that the saturated unit is confined.

The AFD site was established within the Sonora-Mohave Creosotebush-White Bursage Desert Scrub ecological system (Prior-Magee and others, 2007) in a sparsely vegetated area dominated by shadscale (Atriplex confertifolia [(Torr. \& Frém) S. Watson] at an elevation of about 709 m on July 27, 2011 (figs. 4 and $5 B$; table 2). Shadscale is an evergreen shrub (Branson and others, 1976) that is widely distributed in the Mojave Desert. Shadscale is not commonly considered a phreatophyte, but is assumed to transpire groundwater when occurring with phreatophytes such as greasewood (Sarcobatus vermiculatis) in areas of shallow groundwater (Nichols, 1994). It is a desert halophyte (xerohalophyte) classified as a salt excluder because its leaves sequester excess salts in bladder cells, which release the salt back into the environment when the cells rupture (Schirmer and Breckle, 1982).

Shadscale inhabits a wide variety of soil textural classes from fine to sandy, and it prefers well-drained soils where salt concentrations are greatest at depths below $1 \mathrm{~m}$. Root growth has been observed to depths of 1.0-1.1 m (Fernandez and Caldwell, 1975). The mean vegetative cover (in percent) for each cardinal direction (north $=8.5$, east $=3.3$, south $=4.9$, west $=3.8$ ) was based on three different measurements made during spring and summer months (June 2012-May 2013) using the line-transect method (Smith, 1974). Mean canopy height and area were $0.29 \mathrm{~m}$ and $0.28 \mathrm{~m}^{2}$, respectively. The depth to groundwater in the monitoring well shortly after completion $(1.78 \mathrm{~m}$ bls $)$ was higher than first occurrence of groundwater during drilling ( $5.3 \mathrm{~m} \mathrm{bls}$ ) indicating that the saturated unit is confined.

The AFI site was established about halfway between the AFS and AFD sites to collect groundwater-level data and various periodic samples (fig. 4; table 2). Vegetation at the AFI site is similar to the AFD site. The depth to groundwater in the monitoring well (2.27 $\mathrm{m}$ bls) shortly after completion was higher than the first occurrence of groundwater during drilling $(4.0 \mathrm{~m}$ bls $)$ indicating that the saturated unit is confined. 
Western honey mesquite (Prosopis glandulosa var. torreyana [(L.D Benson) M.C. Johnston]), a deciduous, thorny tree is also present in the study area. Honey mesquite has a well-developed root system, but Mojave Desert rainfall is insufficient to provide adequate soil moisture for survival. Honey mesquite is a phreatophyte found typically in alkali sinks, washes, and dry lakes where plants have access to groundwater. General characteristics include an extensive root system that includes lateral roots and a taproot that commonly reaches depths of $12 \mathrm{~m}$ when subsurface water is available (Hauser, 2006), and leaf drop that commonly occurs in November or December (Steinberg, 2001). Honey mesquite near the Amargosa Flat study sites occurs as isolated trees and small clusters, and also is found along washes (fig. 4).

The ADRS was selected as the control site for this study because the saturated zone is deep (about $110 \mathrm{~m}$ ), unsaturatedzone flow processes have been well studied (https://nevada. usgs.gov/water/adrs/biblio.cfm), and ET has been measured continuously since 2002 (Johnson and others, 2007; Garcia and others, 2011; Arthur and others, 2012) (figs. 1 and $5 C$; table 2). An upward net (liquid plus vapor) water flux (about $0.01 \mathrm{~mm} / \mathrm{yr}$ ) has been attributed to deep drying of the unsaturated-zone profile since the last pluvial period (Walvoord and others, 2004). Surface soils are mapped as the Yermo (loamy-skeletal, mixed, superactive, calcareous, thermic Typic Torriorthents)-Arizo (sandy-skeletal, mixed, thermic Typic Torriorthents) association. Subsurface sediments are predominantly fluvial deposits, consisting of several sand and gravel sequences. The ecological system is SonoraMohave Creosotebush-White Bursage Desert Scrub (PriorMagee and others, 2007) and the sparsely vegetated study site is dominated by creosote bush (Larrea tridentata (DC.) Coville), an evergreen shrub (Smith and others, 1997). The root system of creosote bush can exceed $4 \mathrm{~m}$ radially (Gile and others, 1998) and rooting depth generally corresponds with the penetration depth of maximum annual precipitation, about 0.75 to $1 \mathrm{~m}$ at the ADRS (Andraski, 1997). Root-zone soil-water content ranges from 0.02 to $0.14 \mathrm{~m}^{3} / \mathrm{m}^{3}$, and subroot-zone gravelly sand (about 1-2-m depth) water contents show little temporal variability (for example, during 2001-05 values averaged $0.05 \pm 0.009 \mathrm{~m}^{3} / \mathrm{m}^{3}$ [Johnson and others, 2007]). Plant transpiration, soil evaporation, and the capillary break formed by the interface between the finer textured root-zone soil and the underlying gravelly sand all inhibit deeper percolation of precipitation (Fischer, 1992; Andraski, 1997). Using methods that allowed the partitioning of ET into evaporation and transpiration, Garcia and others (2009) reported that the mean annual evaporation to transpiration ratio was 75:25 percent, but the bare-soil evaporation component ranged from as much as 99.8 percent immediately following precipitation to as little as 0.3 percent during sustained dry periods.

\section{Study Methods}

Groundwater discharge by evapotranspiration is computed and characterized using a combination of micrometeorological, unsaturated zone, and stable isotope measurements. Instrumentation for continuous monitoring included eddy-covariance and energy-balance sensors to compute evapotranspiration (figs. 4 and 5), precipitation sensors, matric-potential sensors to evaluate water-flow directions within the unsaturated zone (figs. 4 and 6), and shallow wells equipped with a pressure transducer to measure daily and seasonal water-level fluctuations within the saturated zone (figs. 4 and 6). Periodic soil-moisture measurements also were made using a neutron probe in access tubes at the AFS and AFD sites (fig. 6). Soil samples collected during drilling of the groundwater and unsaturated-zone instrument boreholes were analyzed to characterize unsaturated-zone properties and to determine the initial soil-moisture, chemical, and stableisotope distribution profiles. Periodic samples of precipitation, plant-stem water, soil water, and groundwater were collected and analyzed for stable isotopic compositions of hydrogen and oxygen to evaluate source water(s) contributing to measured evapotranspiration.

\section{Evapotranspiration}

Evapotranspiration is the process that transfers water from land surface to the atmosphere and occurs as evaporation (or sublimation when below freezing) from open water, soil, and plant canopies, and as transpiration from plants. Net radiation $\left(R_{n}\right)$, the difference between incoming and outgoing long-wave and shortwave radiation, is the primary driver of evapotranspiration processes. The largest component of $R_{n}$ is radiative energy from the sun (incoming shortwave radiation). Net radiation is absorbed at the Earth's surface, and then is partitioned into energy that is transferred by heat conducted downward into the subsurface $(G)$, by heat conduction or convection upward into the atmosphere $(H)$, or is used to convert water from the solid or liquid phase to the vapor phase (LE) (Brutsaert, 1982). This partitioning process, which is based on the conservation of energy principle and the first law of thermodynamics, can be expressed as:

$$
R_{n}-G=L E+H
$$

where
$R_{n} \quad$ is net radiation,
$G$ is soil-heat flux,
$L E$ is latent-heat flux, and
$H$ is sensible-heat flux. 


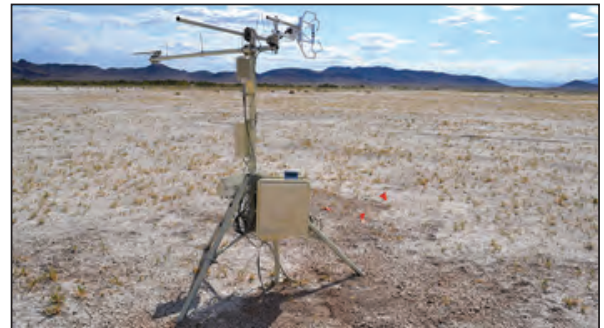

AFS

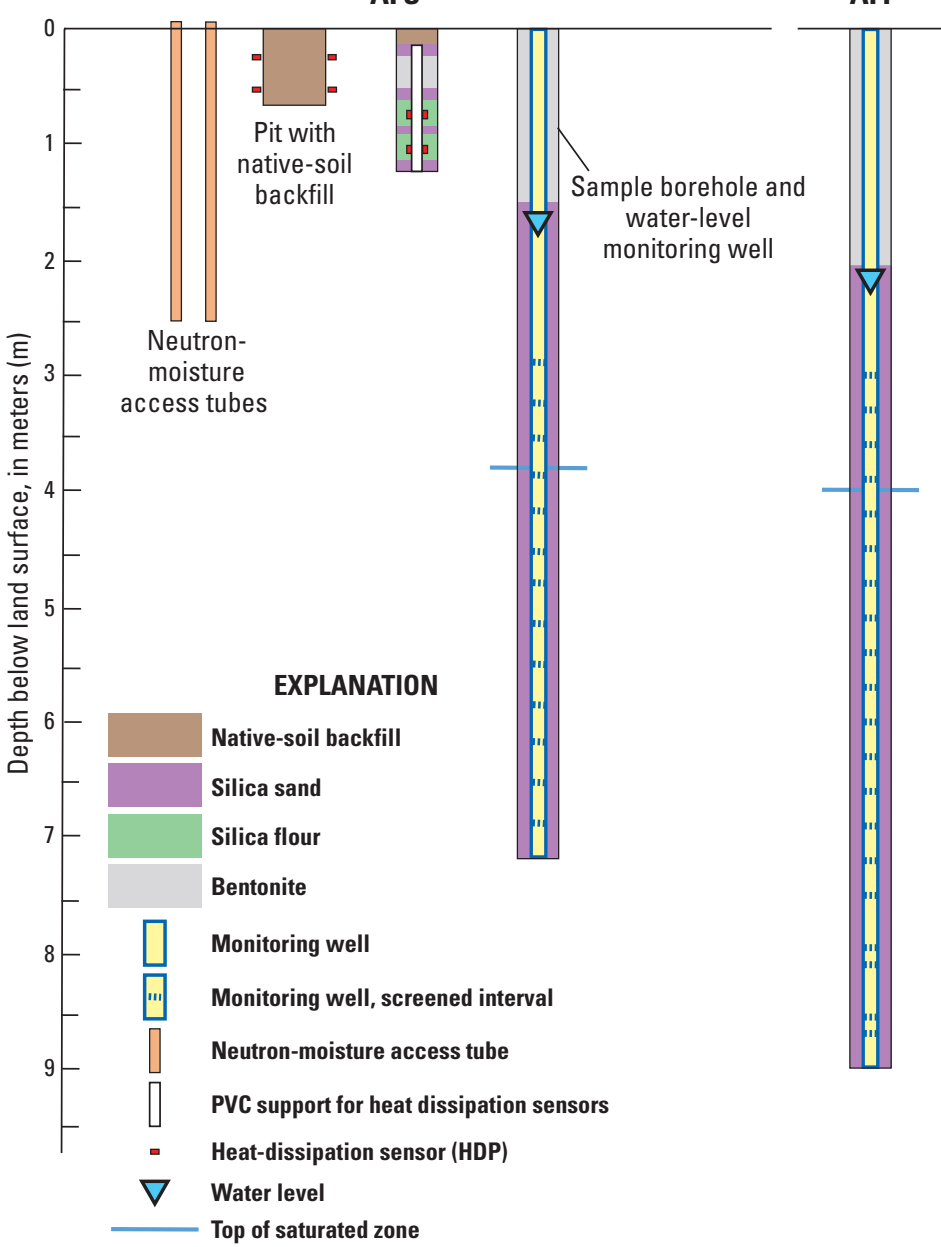

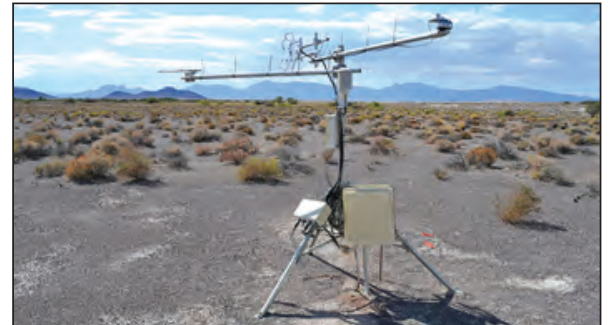

AFD

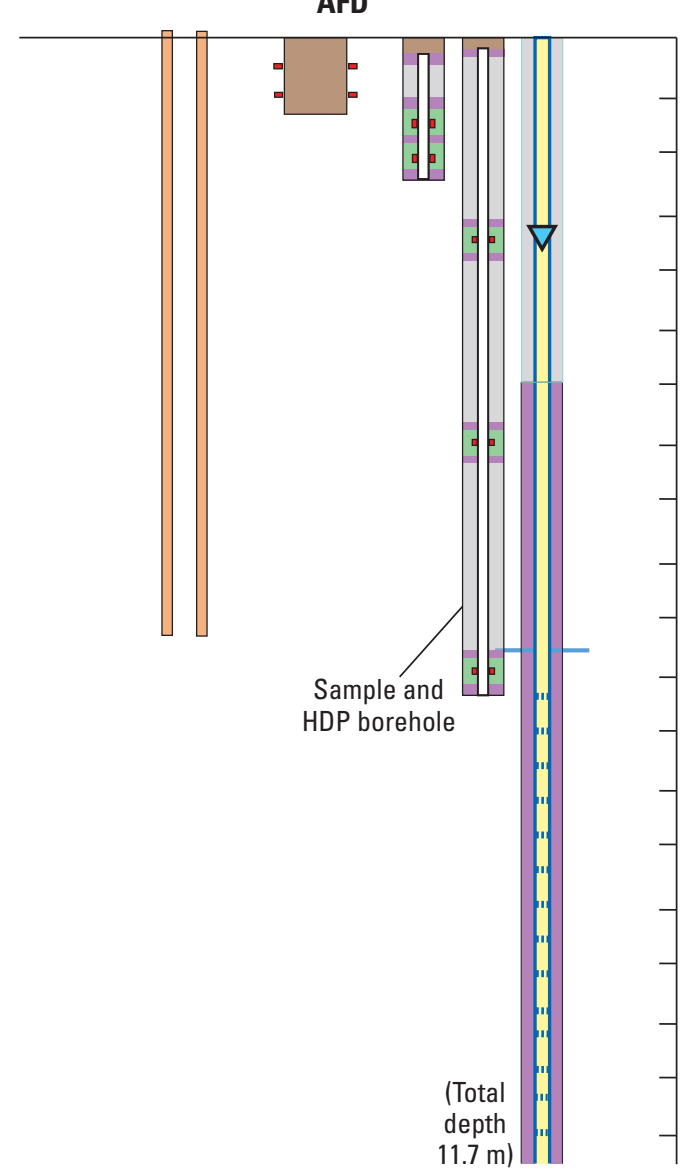

Figure 6. Evapotranspiration, unsaturated zone, and saturated zone measurements at monitoring sites Amargosa Flat Shallow (AFS), Intermediate (AFI), and Deep (AFD), Amargosa Desert, Nye County, Nevada.

All terms are in watts per square meters, and each term is positive during typical daytime conditions. $R_{n}$ is positive when incoming long-wave and shortwave radiation exceeds outgoing long-wave and shortwave radiation, $G$ is positive when heat moves from the surface into the subsurface, and $L E$ and $H$ are positive when moving upward from the surface to the atmosphere. The left side of equation 1 represents the available energy and the right side is the turbulent flux. Energy used for photosynthesis and energy stored as heat in short and sparse canopies are considered negligible for this study and are not accounted in the energy-balance equation (Brutsaert, 1982;
Wilson and others, 2002). A greater proportion of available energy is partitioned into $H$ in arid environments where water supplies are limited; however, following precipitation events, a greater proportion of available energy is partitioned into $L E$ (ET).

An evapotranspiration station was established at each study site and equipped with eddy-covariance and other sensors necessary to independently measure each of the major energy-balance components (eq. 1). Eddies are turbulent airflow caused by wind, surface roughness, and convective heat flow in the atmospheric surface layer (Swinbank, 1951; 
Brutsaert, 1982; Kaimal and Finnigan, 1994). Eddies transfer energy and mass between the land surface and the atmosphere through a process referred to as turbulent energy exchange (Brutsaert, 1982). The eddy-covariance method provides the most direct measure of turbulent-energy flux currently available (Baldocchi, 2003; Foken, 2008; Stannard and others, 2013). Fluxes of water vapor, heat, and other scalars like carbon dioxide can be measured directly without the application of empirical constants (Foken, 2008). Evapotranspiration (positive $L E$ ) occurs when water vapor in upward-moving eddies is greater than in downward-moving eddies. $L E$ is the product of the latent heat of vaporization of water $(\lambda)$ and water-vapor flux density. The latent heat of vaporization, although slightly temperature dependent, is nearly a constant. Water-vapor flux density is calculated as the covariance of instantaneous deviations from the time-averaged product of water-vapor density and vertical wind speed. $L E$ can be expressed mathematically as:

$$
L E=\lambda \overline{w^{\prime} \rho_{v}{ }^{\prime}}
$$

where

$\lambda$ is the latent heat of vaporization, in joules per gram,

$w^{\prime} \quad$ is vertical component of wind speed, in meters per second; and

$\rho_{v}{ }^{\prime} \quad$ is water vapor density, in grams per cubic meters, where the overbar is the mean and the prime is the deviation from the mean over an averaging period.
$H$ is computed from temperature and the vertical component wind speed:

$$
H=\rho_{a} C_{p} \overline{w^{\prime} T_{a}^{\prime}}
$$

where

$\rho_{a} \quad$ is air density, in kilograms per cubic meters, $C_{p}$ is specific heat of air at constant pressure, in joules per kilogram per degrees Celsius, and

$T_{a}^{\prime} \quad$ is air temperature, in degrees Celsius, where the overbar is the mean and the prime is the deviation from the mean over an averaging period.

\section{Instrumentation}

The eddy-covariance method uses fast-response sensors to measure the rapid fluctuations in water-vapor density, wind-speed components, and air temperature to compute $L E$ and $H$. Two specialized sensors were used: a krypton hygrometer (KH2O) measured the water-vapor density fluctuations, and a three-dimensional sonic anemometer (CSAT3) measured the wind vector and air temperature fluctuations (table 3, fig. 7A). A krypton lamp in the KH20 sensor emits an ultraviolet radiation signal along an approximately 1-cm path open to the atmosphere.

Table 3. Instruments used to measure evapotranspiration, energy balance, and precipitation at eddycovariance evapotranspiration sites, Amargosa Desert, Nye County, Nevada.

[Placement: ADRS, Amargosa Desert Research Site; AFD, Amargosa Flat Deep site; AFS, Amargosa Flat Shallow site.

\begin{tabular}{|c|c|c|c|}
\hline Type of measurement & Company name & Model No. and instrument & Placement \\
\hline \multirow[t]{2}{*}{ Evapotranspiration } & \multirow[t]{2}{*}{ Campbell Scientific } & CSAT3 3-D sonic anemometer & \multirow[t]{2}{*}{$2.0 \mathrm{~m}$ als } \\
\hline & & KH20 krypton hygrometer & \\
\hline $\begin{array}{l}\text { Air temperature/ } \\
\text { humidity }\end{array}$ & Vaisala & $\begin{array}{l}\text { HMP45C temperature/ } \\
\text { humidity probe }\end{array}$ & $1.6 \mathrm{~m}$ als \\
\hline Net radiation & Kipp \& Zonen & CNR2 net radiometer & $\begin{array}{l}\text { AFD and AFS: } 1.8 \mathrm{~m} \text { als; } \\
\text { ADRS: } 3.2 \mathrm{~m} \text { als }\end{array}$ \\
\hline Soil temperature & Campbell Scientific & $\begin{array}{l}\text { Two TCAV averaging soil } \\
\text { thermocouple probes }\end{array}$ & 0.02 and $0.06 \mathrm{~m}$ bls \\
\hline Soil moisture & Campbell Scientific & $\begin{array}{l}\text { CS616 water content } \\
\text { reflectometer }\end{array}$ & 0.025 to $0.057 \mathrm{~m}$ bls \\
\hline Soil-heat flux & Hukseflux & Two HFP01 soil heat flux plates & $0.08 \mathrm{~m}$ bls \\
\hline \multirow[t]{2}{*}{ Precipitation } & NovaLynx & 260-2510 standard rain gage & \multirow[t]{2}{*}{$0.86 \mathrm{~m}$ als } \\
\hline & Texas Electronics & $\begin{array}{l}\text { TE525WS tipping bucket } \\
\text { rain gage }\end{array}$ & \\
\hline $\begin{array}{l}\text { Photosynthetic photon } \\
\text { flux density }\end{array}$ & LI-COR & LI190SB quantum sensor & $1.9 \mathrm{~m}$ als \\
\hline Voltage & Campbell Scientific & CR3000 micrologger & $0.9 \mathrm{~m}$ als \\
\hline
\end{tabular}
A bbreviations: 3-D, three-dimensional; als, above land surface; bls, below land surface; m, meter] 

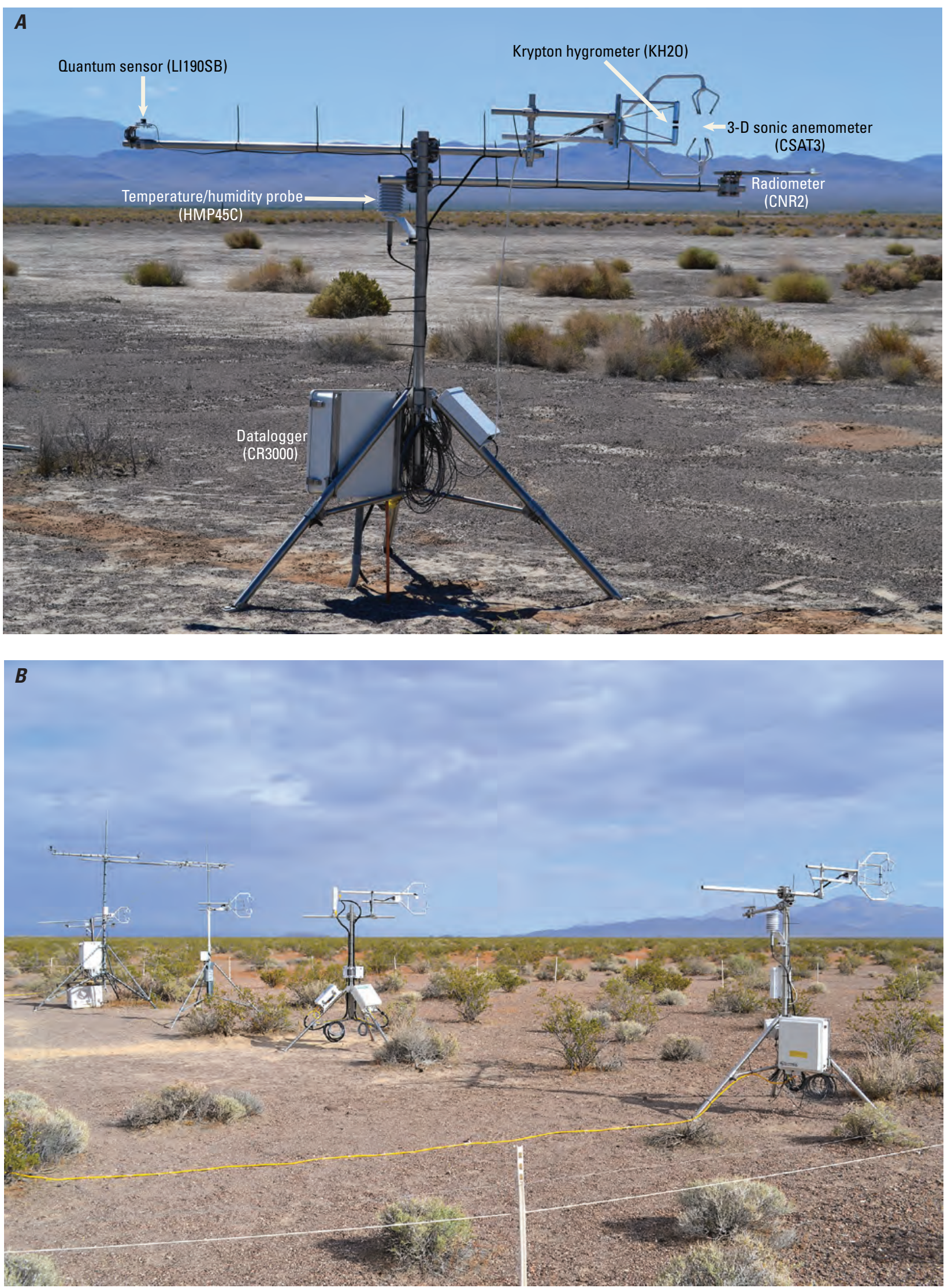

Figure 7. (A) Eddy-covariance station and sensors, Amargosa Flat Deep site, Amargosa Desert, and $(B)$ eddy-covariance station intercomparison, Amargosa Desert Research Site, Nye County, Nevada. Photographs taken by Michael T. Moreo, U.S. Geological Survey, (A) July 2011; (B) May 2011. 
The signal is attenuated according to the Beer-Lambert law as water vapor absorbs specific frequencies of ultraviolet radiation. A voltage output proportional to the attenuated signal is recorded and related to water-vapor density by a regression function (Campbell Scientific, Inc., 2010a). The CSAT3 measures turbulent fluctuations of horizontal and vertical wind speed using three pairs of non-orthogonally oriented transducers to transmit and receive an ultrasonic signal. The Doppler effect relates the flight time of the signal to wind speed (Campbell Scientific, Inc., 2010b). An electronic datalogger received output from these sensors at a frequency of 10 hertz (Hz; 10 times per second). The centers of the $\mathrm{KH} 2 \mathrm{O}$ and CSAT3 signal paths were separated by $10 \mathrm{~cm}$ horizontally, and both sensors were positioned vertically. The CSAT3 was oriented at an azimuth of 220 degrees, and the height of the paired sensors was $2 \mathrm{~m}$ above the land surface during pre-deployment testing at ADRS and during actual site deployment (fig. 5). The orientation and positioning of the sensors were selected to minimize airflow disruptions that could be caused by the support structure and other sensors (fig. 7A).

Pre-deployment testing included a 15-day (July 9-25, 2011) side-by-side comparison between each pair of eddy-covariance sensors (fig. 7B). The purpose of this intercomparison was to achieve consistency between eddycovariance sensors and facilitate subsequent comparative data analyses between sites by minimizing instrument biases. A reference against which to compare $L E$ and $H$ measured by each sensor pair was computed as the mean $L E$ and $H$ from all three sensor pairs. Statistics for the relations between the three-station mean and the individual sensor measurements are given in table 4 . The regression results show the slopes of individual $L E$ relations were within 5 percent of unity and those for $H$ were within 2 percent, and the intercepts and root mean squared differences (RMSDs) were comparable. $L E$ for the ADRS sensors was 4.20 percent higher than the three-station mean, and $L E$ for the AFS and AFD stations were 2.77 and 1.43 percent lower, respectively. $H$ for ADRS and AFD were 0.13 and 1.71 percent lower than the mean, respectively, whereas that for AFS was 1.84 percent higher; therefore, following deployment to the field monitoring sites, the computed daily $L E$ and $H$ for each station were adjusted down or up according to these results.

The two-component (net shortwave and net long-wave radiation) net radiometers (CNR2) used to measure $R_{n}$ also were compared prior to site deployment to reduce instrument bias among the three CNR2s used in the study (Campbell Scientific, Inc., 2009). Each CNR2 was compared with a factory-calibrated four-component (incoming and outgoing shortwave and long-wave radiation) radiometer (CNR1) of higher quality (similar to Blonquist and others, 2009). The side-by-side comparison was done over a bare-soil surface (1.8-m sensor height) at the ADRS during July 19-26, 2011. Based on the results of the comparison, $R_{n}$ data from the CNR2s were biased high by 15.0 to $21.7 \mathrm{~W} / \mathrm{m}^{2}$ compared to the CNR1 and subsequent CNR2 $R_{n}$ data were adjusted downward (table 5). During site deployment, each CNR2 was oriented 180 degrees away from the support structure.

Table 4. Eddy-covariance sensor intercomparison statistics, Amargosa Desert Research Site, Nye County, Nevada, July 9-25, 2011.

[30-minute measurements, $n=768$. Site name: AFS, Amargosa Flat Shallow site; AFD, Amargosa Flat Deep site; ADRS, Amargosa Desert Research Site. 1:1 comparison statistics: Computed with reference (3-station mean) on $\mathrm{x}$-axis and site sensor on y-axis. Slope: Slope of regression line. Intercept: Intercept of regression line. $\mathbf{r}^{2}$ : Coefficient of determination. R M SD: Root mean squared difference. Difference statistics: Computed as site sensor minus reference. M ean: Mean difference from reference. Standard deviation: Standard deviation of difference values. Percentage of mean: Mean difference expressed as a percentage of mean reference value. Abbreviation: $\mathrm{W} / \mathrm{m}^{2}$, watts per square meter]

\begin{tabular}{|c|c|c|c|c|c|c|c|c|}
\hline \multirow[b]{2}{*}{ Parameter } & \multirow[b]{2}{*}{$\begin{array}{c}\text { Site } \\
\text { name }\end{array}$} & \multicolumn{4}{|c|}{ 1:1 comparison statistics } & \multicolumn{3}{|c|}{ Difference statistics } \\
\hline & & Slope & $\begin{array}{c}\text { Intercept } \\
\left(\mathrm{W} / \mathrm{m}^{2}\right)\end{array}$ & $\mathbf{r}^{2}$ & $\begin{array}{l}\text { RMSD } \\
\left(\mathrm{W} / \mathrm{m}^{2}\right)\end{array}$ & $\begin{array}{l}\text { Mean } \\
\left(W / m^{2}\right)\end{array}$ & $\begin{array}{c}\text { Standard } \\
\text { deviation } \\
\left(\mathrm{W} / \mathrm{m}^{2}\right)\end{array}$ & $\begin{array}{l}\text { Percentage } \\
\text { of mean }\end{array}$ \\
\hline \multirow{3}{*}{$\begin{array}{l}\text { Latent-heat } \\
\text { flux }(L E)\end{array}$} & AFS & 0.98 & -0.10 & 0.953 & 3.1 & -0.3 & 3.1 & -2.77 \\
\hline & AFD & 0.97 & 0.23 & 0.942 & 3.4 & -0.2 & 3.4 & -1.43 \\
\hline & ADRS & 1.05 & -0.13 & 0.957 & 3.3 & 0.5 & 3.2 & 4.20 \\
\hline \multirow{3}{*}{$\begin{array}{l}\text { Sensible-heat } \\
\text { flux }(H)\end{array}$} & AFS & 1.02 & 0.02 & 0.992 & 12.7 & 1.8 & 12.6 & 1.84 \\
\hline & AFD & 0.98 & 0.11 & 0.993 & 12.0 & -1.7 & 11.9 & -1.71 \\
\hline & ADRS & 1.00 & -0.12 & 0.992 & 12.3 & -0.1 & 12.3 & -0.13 \\
\hline
\end{tabular}


Table 5. Radiometer intercomparison statistics, Amargosa Desert Research Site, Nye County, Nevada, July 19-26, 2011.

[30-minute measurements, $\mathrm{n}=241.1: 1$ comparison statistics: Computed with reference 4-component radiometer on $\mathrm{x}$-axis and site net radiometers on $\mathrm{y}$-axis; Slope, slope of regression line; Intercept, intercept of regression line; $\mathbf{r}^{2}$, coefficient of determination. R M SD, Root mean squared difference. Difference statistics: Computed as site radiometer minus reference: M ean, mean difference from reference; Standard deviation, standard deviation of difference values; Percentage of mean, mean difference expressed as a percentage of mean reference value. Abbreviations: AFS, Amargosa Flat Shallow site; AFD, Amargosa Flat Deep site; ADRS, Amargosa Desert Research Site; W/m², watts per square meter]

\begin{tabular}{|c|c|c|c|c|c|c|c|}
\hline \multirow[b]{2}{*}{$\begin{array}{c}\text { Site } \\
\text { name }\end{array}$} & \multicolumn{4}{|c|}{ 1:1 comparison statistics } & \multicolumn{3}{|c|}{ Difference statistics } \\
\hline & Slope & $\begin{array}{c}\text { Intercept } \\
\left(\mathrm{W} / \mathrm{m}^{2}\right)\end{array}$ & $\mathbf{r}^{2}$ & $\begin{array}{l}\text { RMSD } \\
\left(\mathrm{W} / \mathrm{m}^{2}\right)\end{array}$ & $\begin{array}{l}\text { Mean } \\
\left(W / m^{2}\right)\end{array}$ & $\begin{array}{c}\text { Standard } \\
\text { deviation } \\
\left(\mathrm{W} / \mathrm{m}^{2}\right)\end{array}$ & $\begin{array}{c}\text { Percentage } \\
\text { of mean }\end{array}$ \\
\hline AFS & 1.07 & 11.37 & 0.999 & 26.2 & 19.2 & 17.9 & 17.70 \\
\hline AFD & 1.06 & 8.30 & 0.999 & 21.6 & 15.0 & 15.5 & 13.90 \\
\hline ADRS & 1.12 & 8.50 & 0.999 & 36.7 & 21.7 & 29.7 & 20.11 \\
\hline
\end{tabular}

Heights above land surface were $1.8 \mathrm{~m}$ for the Amargosa Flat stations and $3.2 \mathrm{~m}$ for the ADRS (figs. 5 and 7). Vegetation distribution at AFD and ADRS was patchy and heterogeneous on a local scale. The CNR2 height at each site was selected so the sensor field-of-view would capture a representative area of shrubs to open ground. Stannard and others (1994) reported that reasonably accurate and consistent $R_{n}$ data can be attained from stations with differing source areas (which is a function of sensor height above land surface) in areas of heterogeneous shrubs if care is taken during horizontal placement of the sensor. The source area for $R_{n}$ measurements is a cosineweighted average circular area with a radius of 10 times the sensor height above land surface (Brotzge and Duchon, 2000; Campbell Scientific, Inc., 2009; table 3). The calculated source area for $R_{n}$ measurements ranged from an average radius of about $18 \mathrm{~m}$ for AFS and AFD, to $32 \mathrm{~m}$ for ADRS.

Soil-heat flux $(G)$ was measured with two soil-heat flux plates (HFP01), two soil-temperature thermocouples (TCAV), and one soil-moisture probe (CS616; table 3). The soil-heat flux plates were placed at a depth of $0.08 \mathrm{~m}$ below land surface and the soil-temperature thermocouples were placed at depths of $0.02 \mathrm{~m}$ and $0.06 \mathrm{~m}$ below land surface as suggested in Campbell Scientific, Inc. (2012). The change in soil temperature and soil-water content measured above each plate was converted to heat flux and added to the mean soil-heat flux measured across the plate. The source area for $G$ measurements is small and limited to an area less than $1 \mathrm{~m}^{2}$ at the sensors.

Data from other instruments listed in table 3 are used in the acquisition, calculation, and evaluation of evapotranspiration data. All instruments were calibrated by the manufacturer shortly before installation and recalibrated according to manufacturer guidelines. Each site was visited approximately monthly for routine site maintenance and data collection, and instruments were routinely checked and evaluated, and repaired or replaced as necessary. The CNR2 and CSAT3 were checked for proper horizontal level and adjusted if necessary, and the CNR2 and KH2O were cleaned with distilled water. Soil moisture and vegetation conditions were documented during each visit.

\section{Data Processing}

Several commonly used corrections must be applied to raw eddy-covariance measurements to compensate for limitations both in the eddy-covariance theory and equipment design. Raw 30-minute block-averaged covariances (eqs. 2 and 3 ) are computed from sampled $10-\mathrm{Hz}$ data after filtering spikes (Højstrup, 1993) and removing any lag between CSAT3 and $\mathrm{KH} 2 \mathrm{O}$ signal outputs. To correct errors associated with small misalignments of the CSAT3, raw covariances are two-dimensionally rotated to align with the mean streamlines of airflow, which forces the mean vertical and crosswind velocities to zero (Kaimal and Finnigan, 1994). Frequency response corrections were applied that compensate for the inability of eddy-covariance sensors to measure contributions from the largest (greater than $1 \mathrm{~km}$ ) and smallest (less than $10 \mathrm{~cm}$ ) eddies due to averaging time and sensor geometry such as path-length averaging and sensor separation (Moore, 1986). The contribution to non-zero average vertical wind speed caused by variations in the density of rising and falling air is corrected following Webb and others (1980). The attenuation of the KH20 signal caused by oxygen in the approximately 1-cm signal path, which is proportional to the sensible-heat flux, was corrected as suggested by Tanner and Greene (1989). In addition, sensible-heat flux $(H)$ was corrected for air density and sound-path deflection of sonic-derived temperatures (Schotanus and others, 1983). All 10-Hz eddy-covariance data were post-processed and corrections applied using EdiRe software (Clement, 1999). 
Poor-quality or unrepresentative 30-minute flux data were identified and removed by applying the following filters: (1) attenuation of the $\mathrm{KH} 2 \mathrm{O}$ millivolt output signal caused by water accumulation during precipitation events, (2) greater than 10 percent of the 18,000 individual CSAT3 measurements for a given 30-minute block average either filtered or missing, and (3) data spikes less than $-150 \mathrm{~W} / \mathrm{m}^{2}$ and greater than $700 \mathrm{~W} / \mathrm{m}^{2}$ (Law and others, 2005). For each site, the total amount of filtered 30-minute latent-heat flux (LE) data (in percent) was: AFS, 1.11; AFD, 1.03; ADRS, 3.68. After questionable data were identified and removed, the resulting gaps were filled using estimated values. The estimation method depended on the gap length. Any gaps in $L E$ or $H$ data occurring for less than 2 hours were filled by linear interpolation between values measured before and after the gap period. For gaps spanning 2 hours or more, the energy balance method outlined in Moreo and others (2007, p. 18) was followed. Daily values were computed from 30-minute gap-filled data for the selected measurement period (November 15, 2011, through November 14, 2013) and compiled in an electronic spreadsheet (Moreo and others, 2017).

\section{Precipitation}

Precipitation data were collected at each study site with a National Weather Service style standard non-recording precipitation gage (table 3). A funnel situated on top of the $20.3 \mathrm{~cm}$ diameter gage directed rain into a $5.1 \mathrm{~cm}$ diameter measuring tube (snowfall was not observed during the study). Precipitation in the measuring tube was determined during monthly site visits using a measuring stick with a resolution of $0.25 \mathrm{~mm}$. Precipitation was allowed to accumulate and the total volume was collected quarterly for stable-isotope analyses. The measuring tube was then wiped clean with a paper towel and $50 \mathrm{~mL}$ of mineral oil was added to prevent the evaporative loss of precipitation that accumulated between monthly readings and quarterly sample collections. Care was taken to add the mineral oil only to the bottom of the measuring tube using a pipette to ensure an accurate depth reading. Any mineral oil/water mixture adhering to the measuring stick after monthly readings was swiped back into the measuring tube. Precipitation event timing and intensity were recorded by a tipping-bucket rain gage collocated with each standard precipitation gage.

All precipitation gages are subject to gage-catch deficiencies that result in an underestimation (negative bias) of the true precipitation (Larsen and Peck, 1974). The primary cause of gage-catch error is wind. A precipitation gage is an obstacle in the wind stream which creates turbulence around the gage orifice. This turbulence deflects precipitation which otherwise would have fallen into the orifice. The error increases as wind speeds increase, and wind speeds decrease following a logarithmic wind profile with decreasing height above the land surface (Campbell and Norman, 1998). To correct for this negative bias, wind speed at the gage-orifice height must be known or estimated. Accordingly, the wind speed during precipitation periods was estimated at the standard rain-gage orifice height $(0.86 \mathrm{~m})$ by adjusting the measured CSAT3 (2.0 m height) wind speed downward to the gage height (Yang and others, 1996):

$$
U(h)=\frac{\left[\ln \left(h / \mathrm{z}_{0}\right)\right]}{\left[\ln \left(H / \mathrm{z}_{0}\right)\right]} U(H)
$$

where
$U(h) \quad$ is the estimated wind speed at the precipitation gage orifice, in meters per second,
$U(H) \quad$ is the measured wind speed by the CSAT3, in meters per second,
$h \quad$ is the height of the precipitation gage orifice above land surface, in meters,
$H \quad$ is the height of the CSAT3 above land surface, in meters, and
$z_{o} \quad$ is the roughness coefficient, in meters, estimated as 0.003 meters for AFS (smooth desert) and 0.05 meters for AFD and ADRS (desert shrubland) (Campbell and Norman, 1998).

$U(h)$ was then used to compute the percentage of precipitation measured ( $R$, or mean gage catch) using the formula from Yang and others (1996):

$$
R=\exp \left(4.605-0.062 * U(h)^{0.58}\right)
$$

The following equation uses $R$ to correct the gage-catch deficiency:

$$
P=\frac{P_{m}}{R} * 100
$$

where

$$
\begin{gathered}
P \quad \text { is the corrected precipitation estimate, in } \\
\text { millimeters, and } \\
P_{m} \quad \text { is the measured precipitation, in millimeters. }
\end{gathered}
$$

Corrections were applied to each standard-gage reading (approximately monthly) and summed for the period of record. Corrected precipitation increased measured precipitation by (in percent): AFS, 11.1; AFD, 9.7; ADRS, 9.3. These corrections are similar to those reported by Yang and others (1996). The $P$ uncertainty is less than 2 percent (Yang and others, 1996; Garcia and others, 2014). Mean annual $P_{m}$, $U(H), U(h), R$, and $P$ for the selected measurement period (November 15, 2011, through November 14, 2013) are given in (table 6). The long-term (1965-2013) mean-annual measured precipitation at a nearby National Weather Service 
Table 6. Mean-annual measured and corrected precipitation, Amargosa Desert, Nye County, Nevada, November 15, 2011, to November 14, 2013.

[Site name: AFS, Amargosa Flat Shallow site; AFD, Amargosa Flat Deep site; ADRS, Amargosa Desert Research Site. $\boldsymbol{P}_{\boldsymbol{m}}$ : Measured precipitation. $\boldsymbol{U}(\boldsymbol{H})$ : Mean wind speed measured by sonic anemometer during precipitation events. $\boldsymbol{U}(\boldsymbol{h})$ : Mean wind speed corrected for gage orifice height. $\boldsymbol{R}$ : Mean gage catch. P: Corrected precipitation estimate. Abbreviations: m/s, meter per second; mm, millimeter]

\begin{tabular}{lccccc}
\hline $\begin{array}{c}\text { Site } \\
\text { name }\end{array}$ & $\begin{array}{c}\boldsymbol{P}_{\boldsymbol{m}} \\
(\mathbf{m m})\end{array}$ & $\begin{array}{c}\boldsymbol{U}(\boldsymbol{H}) \\
(\mathbf{m} / \mathbf{s})\end{array}$ & $\begin{array}{c}\boldsymbol{U}(\boldsymbol{h}) \\
(\mathbf{m} / \mathbf{s})\end{array}$ & $\begin{array}{c}\boldsymbol{R} \\
(\text { percent })\end{array}$ & $\begin{array}{c}\boldsymbol{P} \\
(\mathbf{m m})\end{array}$ \\
\hline AFS & 76 & 3.5 & 3.0 & 88.9 & 85 \\
AFD & 78 & 3.0 & 2.3 & 90.3 & 86 \\
ADRS & 66 & 2.9 & 2.2 & 90.7 & 73 \\
\hline
\end{tabular}

cooperative weather station (110 mm, Amargosa Farms Garey, Nevada [260150], http://www.wrcc.dri.edu/cgi-bin/cliMAIN. pl?nv0150) indicates that precipitation at Amargosa Flat during the study period was about 30 percent below average. A similar comparison between long-term (1981-2011) data for the ADRS (108 mm; Arthur and others, 2012) shows studyperiod precipitation at ADRS was about 40 percent below average.

Because the accuracy of tipping-bucket rain gages typically is limited, 30-minute tipping-bucket data for AFS and ADRS were corrected to equal monthly $P$ estimated for the standard-precipitation gages at those sites. The applied correction was proportional to the wind speed and number of tips during each 30-minute increment. The tipping-bucket record for AFD was not used due to intermittent problems with the gage. Monthly readings from the bulk precipitation gages at AFS and AFD show that $P$ at those sites were almost identical, which was not unexpected considering the sites are only about $580 \mathrm{~m}$ apart (table 6). Thus, the tipping-bucket record for AFS is assumed to be representative of both Amargosa Flat sites. Corrected precipitation data are compiled in Moreo and others (2017).

\section{Groundwater Levels}

To better understand relations among Amargosa Flat precipitation, evapotranspiration, plant, unsaturated-zone, and saturated-zone processes, wells were installed to monitor water-level fluctuations (figs. 4 and 6, table 2). Each well was drilled with an auger rig and cased with schedule 40 flushthreaded $50 \mathrm{~mm}$ polyvinyl chloride pipe. Each monitoring well was completed in a confined unit where the water level in a given well rose between 1.7 and $3.5 \mathrm{~m}$ above the depth of first detection of the saturated zone (table 7). The location and elevation of the measuring point for each well was determined using survey grade Differential Global Positioning System equipment. Water levels were measured approximately monthly using a steel tape. The wells at AFS and AFD also were equipped with a vented-cable transducer to record hourly water-pressure measurements. Pressure measurements were regressed against steel tape measurements to compute a continuous water-level record. Well construction information and computed hourly water-level records are compiled in Moreo and others (2017). Periodic Amargosa Flat (steel tape) and ADRS measurements are archived in the USGS National Water Information System database (https://waterdata.usgs. gov/nwis).

Table 7. General description of saturated zone monitoring sites, Amargosa Flat, Nye County, Nevada.

[Site locations are shown in figures 4 and 6. Elevations are in meters above North American Vertical Datum of 1988. Site name: AFS, Amargosa Flat Shallow site; AFI, Amargosa Flat Intermediate site; AFD, Amargosa Flat Deep site. U.S. Geological Survey site identification: Unique identification number for site as stored in files and data bases of the U.S. Geological Survey. A bbreviations: bls, below land surface; $m$, meter; N/A, not applicable]

\begin{tabular}{cccccccc}
\hline Site & $\begin{array}{c}\text { U.S. Geological } \\
\text { Survey site } \\
\text { name }\end{array}$ & $\begin{array}{c}\text { Elevation } \\
\mathbf{( m )}\end{array}$ & $\begin{array}{c}\text { Well depth } \\
\text { (m bls })\end{array}$ & $\begin{array}{c}\text { Approximate } \\
\text { depth to top of } \\
\text { saturated zone } \\
\text { (m bls) }\end{array}$ & $\begin{array}{c}\text { Depth to water } \\
\text { in well on } \\
\mathbf{1 1 - 1 5}-11 \\
\text { (m bls) }\end{array}$ & $\begin{array}{c}\text { Water-level } \\
\text { elevation } \\
\text { on 11-15-11 } \\
\text { (m) }\end{array}$ & $\begin{array}{c}\text { Period of continuous } \\
\text { measurements }\end{array}$ \\
\hline AFS & 362931116153601 & 707.98 & 7.3 & 3.8 & 1.72 & 706.26 & $11-16-11$ to 12-09-13 \\
AFI & 362927116152401 & 708.95 & 9.0 & 4.0 & 2.27 & 706.68 & N/A \\
AFD & 362924116151301 & 709.08 & 11.7 & 5.3 & 1.78 & 707.30 & $11-15-11$ to 12-09-13 \\
\hline
\end{tabular}




\section{Unsaturated Zone}

The unsaturated zone is an important component in the hydrologic continuum because it controls the amounts of water exchanged with the atmosphere above and the groundwater below, as well as the amount of soil water stored and available for plant uptake. A combination of soil-sampling, laboratoryanalysis, field-monitoring, and flux-estimation techniques were used to characterize unsaturated-zone properties and evaluate processes influencing the direction and magnitude of water movement between the land surface and groundwater at the AFS and AFD sites. Previously published information and active field-monitoring data from the ADRS were used for making relative comparisons between the Amargosa Flat and control-site results. Unsaturated-zone data collected for this study are available in Moreo and others (2017).

\section{Soil Properties and Long-Term Processes Affecting Water Flow}

Soil samples collected during drilling and installation of the AFS and AFD wells and unsaturated-zone instruments were analyzed to characterize the physical, hydraulic, and chemical properties of the unsaturated-zone profiles (figs. 4 and 6). The downhole drive-core samples were contained in stainless-steel cylinders (15.2-mm long, 7.3-mm inside diameter) and near-surface core samples were collected from soil pits using a hand-driven sampler and stainless-steel cylinders (15.2-mm long, 4.9-mm inside diameter). Laboratory analyses included particle-size distribution (Gee and Bauder, 1986), saturated-hydraulic conductivity (Klute and Dirksen, 1986), and soil-water retention (Klute, 1986). The soil particle-size distribution has a strong effect on saturatedhydraulic conductivity because the number and size of the largest water-filled pores determines the rate of transportfor example, under saturated conditions, a sand with mostly large pores can conduct more water than a clay with smaller pores. Soil-water retention is the relation between soil-water content and soil-matric potential for a particular soil. Soilwater content is the amount of liquid water held in the soil and it can be expressed on either a gravimetric basis (mass of water per mass of soil) or a volumetric basis (volume of water per volume of bulk soil [soil + water + air]). Soil-matric potential defines how tightly the water is held in the soil and is negative for unsaturated conditions; lower values indicate drier conditions.

Soil samples collected during drilling also were analyzed to determine the initial moisture and chemical distributions in the vertical profiles. These analyses included soil-water potential—sum of matric and osmotic potentials-(Dew Point PotentiaMeter, Decagon Devices, Inc.; Scanlon and others, 2002), electrical conductivity and chloride concentration (saturated paste and 1-to-10 soil-to-water ratio, respectively; Rhoades, 1986), and stable isotopes of oxygen-18 and deuterium (see section, “Stable Isotopes”). The accuracy of the soil-water potential measurements varies from \pm 1 percent in the dry range ( -300 to $-5 \mathrm{MPa}$ ) to $\pm 0.05 \mathrm{MPa}$ in the wet range ( -5 to $0 \mathrm{MPa}$ ). The soil-osmotic potential is due to dissolved salts in pore water and has little effect on liquid-water flow, but if high salt-concentration gradients are present the soil-osmotic potential can be as effective as soilmatric potential in driving water-vapor flow (Campbell, 1985). Soil-osmotic potential was not measured directly, but its relative contribution to soil-water potential was assessed using electrical-conductivity based estimates (Andraski and Scanlon, 2002). Generally, the osmotic potentials were considered small relative to matric potentials, which on average, accounted for $85 \pm 7$ percent of the soil-water potential. Hereinafter, the term soil-water potential is used interchangeably to describe the matric potential and the sum of the matric-and-osmotic potentials. The initial soil-water potential profiles were used to obtain a snapshot of the energy gradients affecting water movement at the beginning of the study. Knowledge of energy gradients is important because water moves from high to low total potential, which under unsaturated conditions equates with movement from high (less negative) to low (more negative) total potential.

The soil-water potential data also were used in combination with the chloride-profile data to infer long-term flow processes whereby environmental chloride is assumed to be a conservative tracer of liquid water movement that occurred over many years prior to the study. The chloride approach has been used in several previous studies, including work at the ADRS (for example, Phillips, 1994; Tyler and others, 1996; Walvoord and others, 2002; Scanlon and others, 2003; Stonestrom and others, 2003; Walvoord and others, 2004). Chloride is a water-soluble salt that is continuously deposited on the land surface from the atmosphere in both precipitation and dry fallout. This atmospheric chloride then moves into the soil profile with infiltrating precipitation and is carried downward with percolating water. The measured concentration distribution is used to infer long-term processes controlling water movement in the profile.

\section{Soil-Water and Temperature Field Instrumentation and Monitoring}

Unsaturated-zone field monitoring included periodic and hourly measurements. Periodic soil-water-content monitoring at AFS, AFD, and ADRS was done to investigate relative differences in the seasonal amount and changes in the amount of water in the soil profiles. Replicated accesstube measurements were made to maximum depths of $2.25 \mathrm{~m}$ (AFS, $n=2$ tubes), $4.50 \mathrm{~m}$ (AFD, $\mathrm{n}=2$ tubes) (fig. 6), and $13.75 \mathrm{~m}$ (ADRS, $\mathrm{n}=3$ tubes) using a neutron-moisture probe (model 503, Campbell Pacific Nuclear Corp.) (Andraski, 1997; Hignett and Evett, 2002). Access tubes at AFS and AFD were installed in hand-augered holes and the probe was calibrated using soil samples collected at the time of installation. The Amargosa Flat calibration equation for probe measurements 
at a depth of $0.15 \mathrm{~m}$ had a coefficient of determination $\left(\mathrm{r}^{2}\right)$ of 0.91 and standard error of estimate of 0.029 ; the equation for measurements at greater depths had an $\mathrm{r}^{2}$ of 0.75 and standard error of estimate of 0.099. The ADRS neutron-probe calibration details are available in Andraski (1997).

Hourly AFS and AFD soil-water potential and soil temperature data were collected to determine the magnitude and direction of forces driving water movement, and this information was applied in the calculation of unsaturated-zone water fluxes. No active soil-water potential and temperature monitoring was done at the ADRS during this study, but relative comparisons with the Amargosa Flat sites were made using ADRS results from a previous 5-year study (Andraski, 1997). Amargosa Flat soil-water potentials and temperatures were measured at discrete depths using heat-dissipation sensors (model 229, Campbell Scientific, Inc.; Scanlon and others, 2002). Shallow-depth sensors were installed horizontally out from soil-pit walls and deeper sensors were installed vertically in instrument boreholes (fig. 6) using techniques that minimize disturbance of the native sediments and ambient moisture conditions, and that isolate the sensor at the monitoring depth of interest (Andraski and Scanlon, 2002). The heat-dissipation sensors were individually calibrated in the laboratory (Flint and others, 2002). The calibration equation range is 0 to $-1,000 \mathrm{MPa}$, where a mean absolute error of 23 percent was determined over the measurement range of -0.01 to $-35 \mathrm{MPa}$ (Flint and others, 2002).

\section{Soil Water-Flux Calculations}

Water movement in desert unsaturated zones is complicated by strongly coupled liquid-water, water-vapor, and heat-flux processes, and rigorous evaluation of water movement requires the use of numerical models for integrated analysis. The three potential-energy components of soil pore water (matric, osmotic, and gravitational) and the soil temperature can all influence water movement. The total water flux can consist of a sequential process of evaporation, short-range liquid flow, and re-evaporation (Philip and de Vries, 1957), and the liquid and vapor phases can move simultaneously, interdependently, and in opposite directions as a result of potential-energy and temperature gradients in the soil. In areas where soils are dry, vapor flux dominates over liquid flux and the gravitational potential-energy effect on water movement is negligibly small (Campbell, 1985). For example, numerical modeling of water movement in ADRS root-zone soil shows that downward liquid-water flux predominates immediately following episodic precipitation events, but during more common dry periods thermal watervapor flux is the predominant process that varies in direction with seasonal changes in the soil-temperature gradientmaximum-upward fluxes during winter and maximumdownward fluxes during summer (Garcia and others, 2011). Deep unsaturated zone modeling also shows that upward thermal water-vapor flux is the primary contributor to total water flow throughout most of the 110-m deep profile where thermal-vapor flow occurs in response to the geothermal gradient (Scanlon and others, 2003).

For purposes of this field-based study, a single-phase independent process approach was used to estimate the relative magnitude of liquid-water and water-vapor fluxes at each of the instrumented sites. Vertical fluxes of isothermal liquid $\left(q_{L i}\right)$, isothermal vapor $\left(q_{V i}\right)$, and thermal vapor $\left(q_{V t}\right)$ were calculated using laboratory-characterization and fieldmonitoring data, and the AFS and AFD results were compared with published results from the ADRS. Saturated-hydraulic conductivity and soil-water retention measurements were used to compute van Genuchten (1980) parameters and describe the hydraulic properties needed for $q_{L i}, q_{V i}$, and $q_{V t}$ calculations, and clay content was used to estimate the enhancement factor for $q_{V t}$ calculations (Campbell, 1985). Hourly field measurements of soil-water potential and temperature, calculated gravitational potential, and estimates of field osmotic potential were used to establish soil-moisture levels and determine gradients driving the isothermal and thermal fluxes.

The soil-water retention relation is described as (van Genuchten, 1980):

$$
\theta(h)=\frac{\left(\theta_{s-} \theta_{r}\right)}{\left[1+\alpha(-h)^{N}\right]^{M}}+\theta_{r}
$$

where

$\theta \quad$ is the volumetric water contents, in cubic centimeters per cubic centimeter,

$h \quad$ is the matric potential (expressed in units of length, in centimeters), and

$\theta_{s} \quad$ is the saturated volumetric water, in cubic centimeters per cubic centimeter.

Curve-fitting parameters determined from soil-water retention measurements include $\theta_{r}$, in cubic centimeters per cubic centimeter, $\alpha$ ( 1 per centimeter), $\mathrm{N}$ (unitless), and $\mathrm{M}(1-1 / \mathrm{N})$. The $q_{L i}$ is described as (Phillip and de Vries, 1957):

$$
q_{L i}=-K_{L i}\left(\frac{d H}{d z}\right)=-K_{L i}\left(\frac{d h}{d z}+1\right)
$$

where

$K_{L i} \quad$ is the van Genuchten (1980) isothermal-liquid hydraulic conductivity, in centimeters per second calculated as the geometric mean for the two depths in the interval,

$H \quad$ is the hydraulic head $(h+z)$,

$z \quad$ is depth, in centimeters, and

$(d h / d z+1) \quad$ is the hydraulic gradient. 
The $q_{V i}$ is described as (Fayer, 2000; with Millington and Quirk [1960] tortuosity factor):

$$
q_{V i}=-K_{V i}\left(\frac{d w}{d z}\right)
$$

where

$K_{V i} \quad$ is the isothermal-vapor conductivity, in centimeters per second, corrected for the effects of in-situ temperature and calculated as the arithmetic mean for the two depths in the interval,

$w \quad$ is the soil-water potential (sum of matric and osmotic potentials, expressed in units of length, in centimeters), and

$(d w / d z) \quad$ is the soil water-potential gradient.

The $q_{V t}$ is described as (Fayer, 2000; with Millington and Quirk [1960] tortuosity factor):

$$
q_{V t}=-K_{V t} \frac{d T}{d z}
$$

where

$$
\begin{aligned}
& K_{V t} \quad \begin{array}{l}
\text { is the thermal-vapor conductivity, in } \\
\text { centimeters per second, corrected for } \\
\text { the effects of in-situ temperature and } \\
\text { calculated as the arithmetic mean for the } \\
\text { two depths in the interval, and }
\end{array} \\
& d T / d z \quad \text { is the temperature gradient. }
\end{aligned}
$$

\section{Stable Isotopes}

The water that contributes to total ET can be derived from precipitation, groundwater, or a combination of both. The individual or combined source-water contributions to evaporation from the soil surface and transpiration from plants can vary in space and in time, and are dependent on several factors such as soil type, plant type, plant-rooting depth, and depth to groundwater. Stable isotopic compositions of hydrogen and oxygen have been used as conservative water-mass tracers to investigate soil-water movement in the unsaturated zone (Barnes and Allison, 1988; Walvoord and others, 2004) and to estimate water sources contributing to plant growth or total ET (White and others, 1985; Ehleringer and others, 1991; Chimner and Cooper, 2004; Scott and others, 2005).

The utility of stable hydrogen and oxygen isotopes in terrestrial-plant studies is based on two fundamental observations: (1) the isotopic composition of the soil water is not altered during water uptake by plant roots and (2) the isotopic composition of xylem water typically remains unaltered during transport between the root and the shoot, until it reaches tissues undergoing evaporative water loss (that is, leaves or non-suberized stems) (Ehleringer and Dawson, 1992). Therefore, analysis of unaltered xylem water before it is exposed to evaporative processes provides an isotopic signature that is an integrated measure of overall plant-water uptake, reflecting the various zone(s) and depth(s) from which the plant is currently extracting soil water. For most species the hydrogen- and oxygen-isotopic compositions of soil water remain unaltered during plant-water uptake, but studies have documented the occurrence of hydrogen-isotopic fractionation in halophytic coastal-wetland species (Lin and Sternberg, 1993) and in honey mesquite (Ellsworth and Williams, 2007). In such cases, only the oxygen-isotopic composition is used in water-uptake-water-source assessment. Because isotopic compositions mix conservatively, the signatures of the precipitation and groundwater endmembers have sometimes been used to quantify the proportions of precipitation and groundwater contributing to plant water uptake. The stable hydrogen and oxygen isotopic compositions of environmental samples are expressed as delta values relative to Vienna Standard Mean Ocean Water and are defined as:

$$
\left.\delta^{2} \mathrm{H}=\left[\left({ }^{2} \mathrm{H} /{ }^{1} \mathrm{H}\right)_{\text {sample }} /\left({ }^{2} \mathrm{H} /{ }^{1} \mathrm{H}\right)_{\text {standard }}\right)-1\right] \times 1,000
$$

$$
\left.\delta^{18} \mathrm{O}=\left[\left({ }^{18} \mathrm{O} /{ }^{16} \mathrm{O}\right)_{\text {sample }} /\left({ }^{18} \mathrm{O} /{ }^{16} \mathrm{O}\right)_{\text {standard }}\right)-1\right] \times 1,000
$$

where

$\begin{aligned} \delta^{2} \mathrm{H} & \text { is the hydrogen isotopic composition, } \\ { }^{2} \mathrm{H} /{ }^{1} \mathrm{H} & \text { is the hydrogen isotope ratio, } \\ \delta^{18} \mathrm{O} & \text { is the oxygen isotopic composition, and } \\ { }^{18} \mathrm{O} /{ }^{16} \mathrm{O} & \text { is the oxygen isotope ratio. }\end{aligned}$

Source water(s) contributing to ET were investigated using periodic sampling and measurement of $\delta^{2} \mathrm{H}$ and $\delta^{18} \mathrm{O}$ in precipitation, groundwater, soil water, and plant water (table 8). Accumulated precipitation was sampled from the standard precipitation gages and the results represent a composite of rain that fell during the preceding quarter. Groundwater was sampled three times at the Amargosa Flat sites and once at the ADRS. Samples were collected after removing three wellcasing volumes of water with a pump. Soil-water samples from the full unsaturated-zone profile were collected at each of the Amargosa Flat sites during drilling and instrumentation in November 2011 (fig. 6), and shallow-soil water samples were collected quarterly using a hand-operated sub-soil probe (Environmentalist, JMC Soil Samplers, Clements Associates, Inc.) at AFS, AFD, and ADRS. The quarterly samples included a 0.2-m-long depth interval that encompassed all or a primary portion of the root zone at each site: AFS, 0-0.2 m; AFD, 0.4-0.6-m; and ADRS, 0.2-0.4 m. Plant-water samples were collected from the dominant species at each site: AFS, saltgrass; AFD and AFI, shadscale; and ADRS, creosote bush. Shadscale and creosote bush samples were collected from woody stems. The aboveground portion of saltgrass, however, 
Table 8. Stable isotope samples of oxygen $\left(\delta^{18} 0\right)$ and hydrogen $\left(\delta^{2} \mathrm{H}\right)$ collected at study sites, Amargosa Desert, Nye County, Nevada, 2011-13.

[Site name: ADRS, Amargosa Desert Research Site; AF, Amargosa Flat Mesquite sites; AFD, Amargosa Flat Deep site; AFI, Amargosa Flat Intermediate site; AFS, Amargosa Flat Shallow site]

\begin{tabular}{|c|c|c|c|c|c|c|c|}
\hline $\begin{array}{c}\text { Sample } \\
\text { type }\end{array}$ & $\begin{array}{c}\text { Site } \\
\text { name }\end{array}$ & $\begin{array}{c}\text { July-November } \\
2011\end{array}$ & $\begin{array}{c}\text { November 2011- } \\
\text { January } 2012\end{array}$ & $\begin{array}{c}\text { January-May } \\
2012\end{array}$ & $\begin{array}{l}\text { May-August } \\
2012\end{array}$ & $\begin{array}{c}\text { August-November } \\
2012\end{array}$ & \\
\hline \multirow{6}{*}{ Precipitation } & AFS & $\mathrm{X}$ & $\mathrm{X}$ & $\mathrm{X}$ & $\mathrm{X}$ & & \\
\hline & AFI & & $\mathrm{X}$ & $\mathrm{X}$ & $\mathrm{X}$ & & \\
\hline & AFD & $\mathrm{X}$ & $\mathrm{X}$ & $\mathrm{X}$ & $\mathrm{X}$ & & \\
\hline & ADRS & & $\mathrm{X}$ & $\mathrm{X}$ & $\mathrm{X}$ & $\mathrm{X}$ & \\
\hline & & November & February & May & & & April \\
\hline & & 2011 & 2012 & 2012 & & & 2013 \\
\hline \multirow[t]{6}{*}{ Groundwater } & AFS & $\mathrm{X}$ & $\mathrm{X}$ & $\mathrm{X}$ & & & \\
\hline & AFI & $\mathrm{X}$ & $\mathrm{X}$ & $\mathrm{X}$ & & & \\
\hline & AFD & $\mathrm{X}$ & $\mathrm{X}$ & $\mathrm{X}$ & & & \\
\hline & ADRS & & & & & & $\mathrm{X}$ \\
\hline & & November & January & May & August & October & \\
\hline & & 2011 & 2012 & 2012 & 2012 & 2012 & \\
\hline \multirow[t]{4}{*}{ Soil water } & AFS & $\mathrm{X}$ & $\mathrm{X}$ & $\mathrm{X}$ & $\mathrm{X}$ & & \\
\hline & AFI & $\mathrm{X}$ & & & & & \\
\hline & AFD & $\mathrm{X}$ & $\mathrm{X}$ & $\mathrm{X}$ & $\mathrm{X}$ & & \\
\hline & ADRS & & & $\mathrm{X}$ & $\mathrm{X}$ & $\mathrm{X}$ & \\
\hline \multirow[t]{5}{*}{ Plant water } & AFS & $\mathrm{X}$ & $\mathrm{X}$ & $\mathrm{X}$ & $\mathrm{X}$ & & \\
\hline & AFI & $\mathrm{X}$ & $\mathrm{X}$ & $\mathrm{X}$ & $\mathrm{X}$ & & \\
\hline & AFD & $\mathrm{X}$ & $\mathrm{X}$ & $\mathrm{X}$ & $\mathrm{X}$ & & \\
\hline & $\mathrm{AF}$ & $\mathrm{X}$ & $\mathrm{X}$ & $\mathrm{X}$ & $\mathrm{X}$ & & \\
\hline & ADRS & & $\mathrm{X}$ & $\mathrm{X}$ & $\mathrm{X}$ & $\mathrm{X}$ & \\
\hline
\end{tabular}

consists of leafy shoots that increase the potential for isotopic fraction errors. Therefore, saltgrass samples were from root segments collected in the upper $0.15 \mathrm{~m}$ of the soil profile. Plant samples were cut from multiple plants and composited into a single sample, and replicate $(\mathrm{n}=2)$ composites were collected during each quarterly sampling. For comparison with the saltgrass and shadscale results, honey mesquite stems were similarly sampled at three locations near the AFS, AFI, and AFD sites (fig. 4): (1) from five trees in a bosque along the wash $500 \mathrm{~m}$ south of the AFS ET site, (2) from three trees in a bosque $80 \mathrm{~m}$ northwest of the AFI SZ site, and (3) from a single tree located about $230 \mathrm{~m}$ southwest of the AFD ET site. All samples were immediately sealed in airtight containers and stored on ice until processed.

All $\delta^{18} \mathrm{O}$ and $\delta^{2} \mathrm{H}$ analyses were done at the USGS Stable Isotope Laboratory in Reston, Virginia. Soil and plant waters were extracted for analysis using azeotropic distillation with toluene (Révész and Woods, 1990). For honey mesquite, only the $\delta^{18} \mathrm{O}$ results were evaluated for this report because fractionation during root water uptake can result in a plantwater $\delta^{2} \mathrm{H}$ signature that is significantly different from its source-water signature (Ellsworth and Williams, 2007). Studies of halophytic coastal-wetland species also have documented fractionation effects on plant-water $\delta^{2} \mathrm{H}$ signatures
(Lin and Sternberg, 1993), but no such studies are known to have been done on desert halophytes. Thus, the Amargosa Flat saltgrass and shadscale results presented herein include both $\delta^{2} \mathrm{H}$ and $\delta^{18} \mathrm{O}$. All stable isotopic composition data are archived in the USGS National Water Information System database (https://waterdata.usgs.gov/nwis).

\section{Groundwater Discharge by Evapotranspiration}

Evapotranspiration and GWET was estimated and characterized at three sites over 2 years with a combination of micrometeorological, unsaturated zone, and stable-isotope measurements. Groundwater ET rates and uncertainty were determined from continuous eddy-covariance ET and precipitation measurements. Unsaturated-zone laboratoryanalysis, field-monitoring, and water-flux estimates were used to characterize soil properties and evaluate processes influencing the direction and magnitude of water movement between the land surface and groundwater. Stable isotopic compositions of oxygen $\left(\delta^{18} \mathrm{O}\right)$ and hydrogen $\left(\delta^{2} \mathrm{H}\right)$ were used as conservative water-mass tracers to investigate water 
movement in the atmosphere-plant-soil-groundwater continuum. Results from this study are compared with results from previous studies.

\section{Context for Results}

A substantial amount of groundwater discharging in southern Amargosa Desert originates as precipitation falling on the Spring Mountains (fig. 1; Winograd and Thordarson, 1975). The highest point in the Mojave Desert (3,652 m), and comprised primarily of exposed Paleozoic limestone flanked by extensive alluvial fans, the Spring Mountains are the dominant source of aquifer recharge in southern Nevada. Snowmelt at high elevations infiltrates the ground surface, recharges underlying aquifers, and flows to discharge areas in adjacent groundwater basins (Winograd and others, 1998; Moreo and others, 2014, and references therein). Some of this water recharges the Ash Meadows groundwater subbasin and moves downgradient into southern Amargosa Desert through a highly transmissive area of a regional carbonate-rock aquifer (Winograd and Thordarson, 1975; Fenelon and Moreo, 2002; Fenelon and others, 2016, pl. 1).

There is an upward hydraulic gradient in southern Amargosa Desert that is characteristic of groundwater discharge areas (Winograd and Thordarson, 1975). The hydraulic head in the carbonate aquifer beneath Amargosa Flat is represented by water levels in Tracer Well 3 (USGS site identifier $363213116133800 ; 719.3 \mathrm{~m} ; 5.5 \mathrm{~km}$ northeast of study area) and Devils Hole (362532116172700; 718.7 m; fig. 3). The mean hydraulic head in AFS and AFD monitoring wells (about $706.9 \mathrm{~m}$ ) is lower than heads at Tracer Well 3 and Devils Hole; therefore, a positive vertical hydraulic gradient exists for moving water upward from carbonate to overlying alluvial units and to the land surface provided a permeable pathway is available. Despite this upward gradient, the upward movement of regional groundwater in southern Amargosa Desert is limited by widespread deposits of finegrained sedimentary rocks. Taylor and Sweetkind (2014) reported that (1) the southern Amargosa Desert basin is filled with an essentially uniform accumulation of fine-grained clay-dominated deposits, (2) at $500 \mathrm{~m}$ elevation playa and palustrine deposits are well-developed in Amargosa Flat, and (3) at $400 \mathrm{~m}$ elevation playa or palustrine deposits dominate most of Amargosa Desert. As a result, about 95 percent of the $22.8 \mathrm{Mm}^{3}$ (18.5 Kaf) discharging from the Ash Meadows groundwater subbasin annually occurs through springs in Ash Meadows (Laczniak and others, 1999, 2001; Fenelon and others, 2016).

Ash Meadows contains about 30 springs along a 16-km-long spring line that trends north-northwest. Although the springs discharge through mainly Quaternary and Tertiary lakebed deposits, their water originates from the underlying carbonate-rock aquifer (Winograd and Thordarson, 1975, p. 80). Water from the carbonate aquifer is diverted to the land surface by one or more normal faults that create a barrier to groundwater flow by juxtaposing low permeability
Cenozoic valley-fill deposits against the carbonate aquifer. Immediately west of the spring line, valley-fill sediments become saturated by upward flow from the carbonate aquifer and by recycled spring flow infiltrating the shallow valleyfill deposits (Laczniak and others, 1999, p. 9). Extensive and diverse phreatophyte populations are sustained by shallow groundwater associated with $97.1 \mathrm{~km}^{2}$ of these spring-fed wetlands. The Ash Meadows National Wildlife Refuge was established in 1984 and the U.S. Fish and Wildlife Service has groundwater rights to $21 \mathrm{Mm}^{3}$ (17 Kaf) annually (Office of the State Engineer, 2007).

Less than 5 percent $\left(<1.2 \mathrm{Mm}^{3}\right.$ [1 Kaf]) of groundwater moving through the Ash Meadows groundwater subbasin to discharge areas in Ash Meadows is diverted upward from the Paleozoic carbonate aquifer and discharges to the Cenozoic rocks underlying Amargosa Flat (Winograd and Thordarson, 1975, p. C78-C84; Laczniak and others, 2001). Most of the phreatophyte discharge in Amargosa Flat is on the northeast and east sides of the playa suggesting the possibility that the regional flow of groundwater is impeded there (figs. 3 and 4; Fenelon and others, 2016, pl. 1). Some of this flow likely is diverted upward to near land surface by the fine-grained playa sediments and discharges predominately through mesquite bosques in washes adjacent to the playa, and through the playa surface. Mesquite bosques are prevalent in washes where, in addition to subsisting on a consistent supply of regional groundwater, a sporadic but important local supply of water is provided by focused infiltration of ephemeral runoff resulting from episodic precipitation events (see sections, "Groundwater-Level Fluctuations" and "Stable Isotope Water Sourcing"; Stonestrom and others, 2003, 2007). Some regional groundwater flows around the playa into the shallow alluvium, and where hydraulically connected, to localized points of discharge (for example, the Amargosa Flat study area).

\section{Evapotranspiration}

The mean annual $(\mathrm{n}=2)$ total $E T$ for AFS (135 mm) was 32 percent greater than AFD (102 mm) and 63 percent greater than ADRS (83 mm) (table 9). Daily total ET and precipitation are shown in figures $8 A$ and $8 B$. Temporal changes for ADRS indicate that total ET increased substantially following precipitation, but then decreased relatively quickly to less than $0.2 \mathrm{~mm} / \mathrm{d}$. These observations are similar to those reported by previous investigators (Johnson and others, 2007; Garcia and others, 2009). Like the ADRS, the AFS and AFD daily total $E T$ also show large increases in response to precipitation (fig. 8B). Unlike the ADRS, however, the Amargosa Flat sites both showed a consistent underlying temporal trend whereby total ET increased from winter-tosummer and decreased from summer-to-winter. There was a strong correlation $(r=0.94)$ between AFS and AFD daily total $E T$, but values for AFS typically exceeded those for AFD throughout the measurement period.

Possible water sources contributing to total ET measured at the study sites include precipitation, surface-water run-on, 

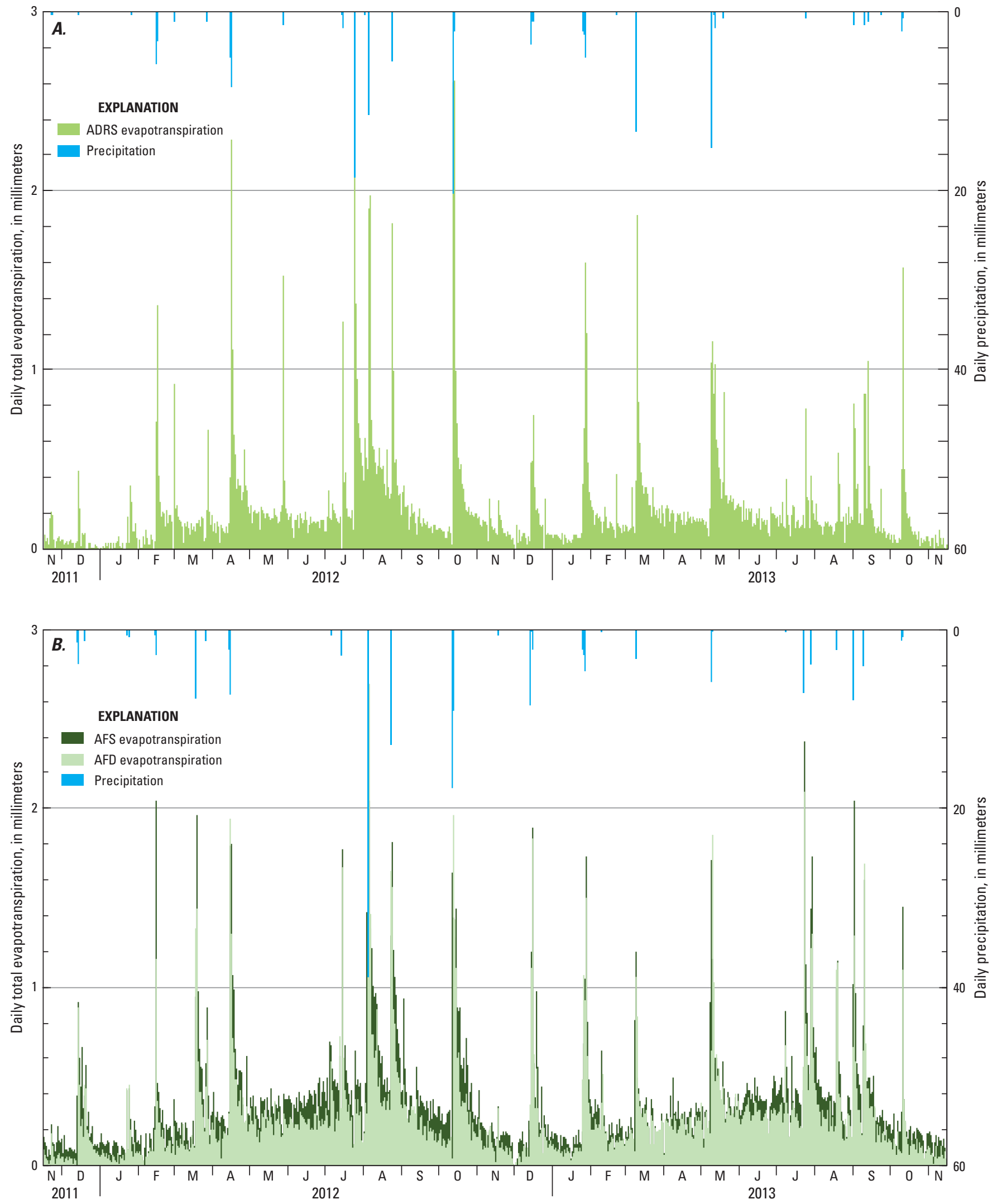

Figure 8. Daily total evapotranspiration and precipitation at (A) Amargosa Desert Research Site (ADRS) and (B) Amargosa Flat Shallow (AFS) and Amargosa Flat Deep (AFD) sites, Amargosa Desert, Nye County, Nevada, November 15, 2011, to November 14, 2013. 
Table 9. Mean annual total evapotranspiration, precipitation, and groundwater evapotranspiration, and uncertainties for each variable, Amargosa Desert, Nye County, Nevada, November 15, 2011, to November 14, 2013.

[Units of measure are in millimeters per year. Site name: AFS, Amargosa Flat Shallow site; AFD, Amargosa Flat Deep site; ADRS, Amargosa Desert Research Site. ET: Total evapotranspiration. P: Precipitation. GWET: Groundwater evapotranspiration, computed using equation 13. Abbreviations: \pm , plus or minus; N/A, not applicable]

\begin{tabular}{|c|c|c|c|c|c|c|}
\hline $\begin{array}{c}\text { Site } \\
\text { name }\end{array}$ & $E T$ & $\begin{array}{c}E T \\
\text { uncertainty } \\
( \pm)\end{array}$ & $P$ & $\begin{array}{c}P \\
\text { uncertainty } \\
( \pm)\end{array}$ & GWET & $\begin{array}{c}\text { GWET } \\
\text { uncertainty } \\
( \pm)\end{array}$ \\
\hline AFS & 135 & 20 & 85 & 2 & 50 & 20 \\
\hline AFD & 102 & 15 & 86 & 2 & 16 & 15 \\
\hline ADRS & 83 & 12 & 73 & 2 & ${ }^{1} 0$ & N/A \\
\hline
\end{tabular}

${ }^{1} G W E T$ defined as 0 (see section, "Evapotranspiration Uncertainty").

the advection of water vapor from exogenous water sources (for example, irrigated fields, spring discharge areas), and groundwater. Precipitation was a contributing water source at all sites. Surface-water run-on from excess precipitation and the advection of water vapor from moist areas should always be considered because these water sources originate outside of but may move into the eddy-covariance measurement area. The dry and coarse-textured soils, flat topography, and relatively infrequent rainfall at ADRS are such that surfacewater run-on is rare and was not observed during the study. Similarly, there was no evidence of run-on at the Amargosa Flat sites during the measurement period. Eddy-covariance measurements likely were not affected by water-vapor advection (primarily by downslope drainage) based on topography and distance: (1) irrigated fields in the Amargosa Farms area are located about $30 \mathrm{~km}$ from ADRS and $25 \mathrm{~km}$ from the Amargosa Flat study area, and downslope from both areas, and (2) Ash Meadows is about $50 \mathrm{~km}$ and downslope from ADRS, and about $10 \mathrm{~km}$ from the Amargosa Flat study site but separated by a topographic high.

Accordingly, annual GWET at the Amargosa Flat sites was computed by subtracting corrected precipitation from total ET:

$$
G W E T=E T-P+\Delta S
$$

where

$\begin{aligned} & \text { GWET } \text { is groundwater discharge by } \\ & \text { evapotranspiration, } \\ & E T \text { is total evapotranspiration, } \\ & P \text { is the corrected precipitation estimate, and } \\ & \Delta S \text { is the difference in soil-moisture storage in the } \\ & \text { unsaturated zone profile at the beginning } \\ & \text { and end of the measurement period. } \\ & \text { The measurement period for the study } \\ & \text { (November 15, 2011, to November 14, }\end{aligned}$

2013) was selected specifically to minimize $\Delta S$ to negligible levels.

All terms are in millimeters per year.

Based on equation 13 results for AFS and AFD (table 9), the following observations can be made:

1. The computed mean annual GWET rate for AFS ( $50 \mathrm{~mm} / \mathrm{yr}$ ) was about 3 times greater than that for AFD (16 mm/yr). The GWET volume was computed by assuming a $200-\mathrm{m}$ fetch at each site with a circular area of 126,000 $\mathrm{m}^{2}$ (see section, "Source Area and Fetch Considerations"). This area multiplied by the GWET rate at each respective site equals $0.006 \mathrm{Mm}^{3}$ (4.8 acre-ft) at AFS and $0.002 \mathrm{Mm}^{3}$ (1.5 acre-ft) at AFD.

2. The computed groundwater contribution to total ET was 37 percent for AFS and 16 percent for AFD.

3. The cumulative difference in daily total ET (AFS minus AFD) totaled $66 \mathrm{~mm}$ for the 2-year measurement period (fig. 9). This indicated that daily GWET for AFS was typically greater than that for AFD because $P$ at both sites was nearly equal (table 9 ). The cumulative difference in total ET was fairly linear through the measurement period, but changes in the slope of the line also indicated seasonal differences between daily total ET for AFS and AFD. For example, the steepening slopes from June to November during both years reflect periods when daily total $E T$ for AFS increased at a faster rate than that for AFD, and the decreasing slopes from November to June reflect periods when the difference between sites decreased.

Additional results regarding the subsurface processes controlling GWET at AFS and AFD are in sections, "Groundwater-Level Fluctuations," "Flow of Water in Unsaturated Soil," and "Stable Isotope Water Sourcing."

Groundwater evapotranspiration was not unexpected at AFS considering saltgrass has long been recognized as an indicator of shallow groundwater (Lee, 1912; Meinzer, 1927; Blaney and others, 1933). Robinson (1958, p. 56-59, fig. 7, table 2) compiled data from previous saltgrass studies and reported strong relations between increasing water-table depths and decreasing GWET rates. Depths to groundwater at 26 sites dominated by saltgrass in California, Utah, and Colorado ranged from $0.09 \mathrm{~m}$ to $1.50 \mathrm{~m}$ bls and GWET rates ranged from $1,240 \mathrm{~mm} / \mathrm{yr}$ at sites with shallower groundwater to $338 \mathrm{~mm} / \mathrm{yr}$ at sites with deeper groundwater. The annual GWET rate estimated for AFS (50 $\mathrm{mm}$ ) is lower than those compiled by Robinson (1958), which likely is partly due to the greater depth to groundwater (3.8 $\mathrm{m}$ bls) at the site. Saltgrass has been observed where the water table lies at greater depths-Meinzer (1927, p. 22) noted saltgrass occurrence adjacent to a playa where depth to water slightly exceeded 3 m bls, and Blaney and others (1933, p. 50) observed 


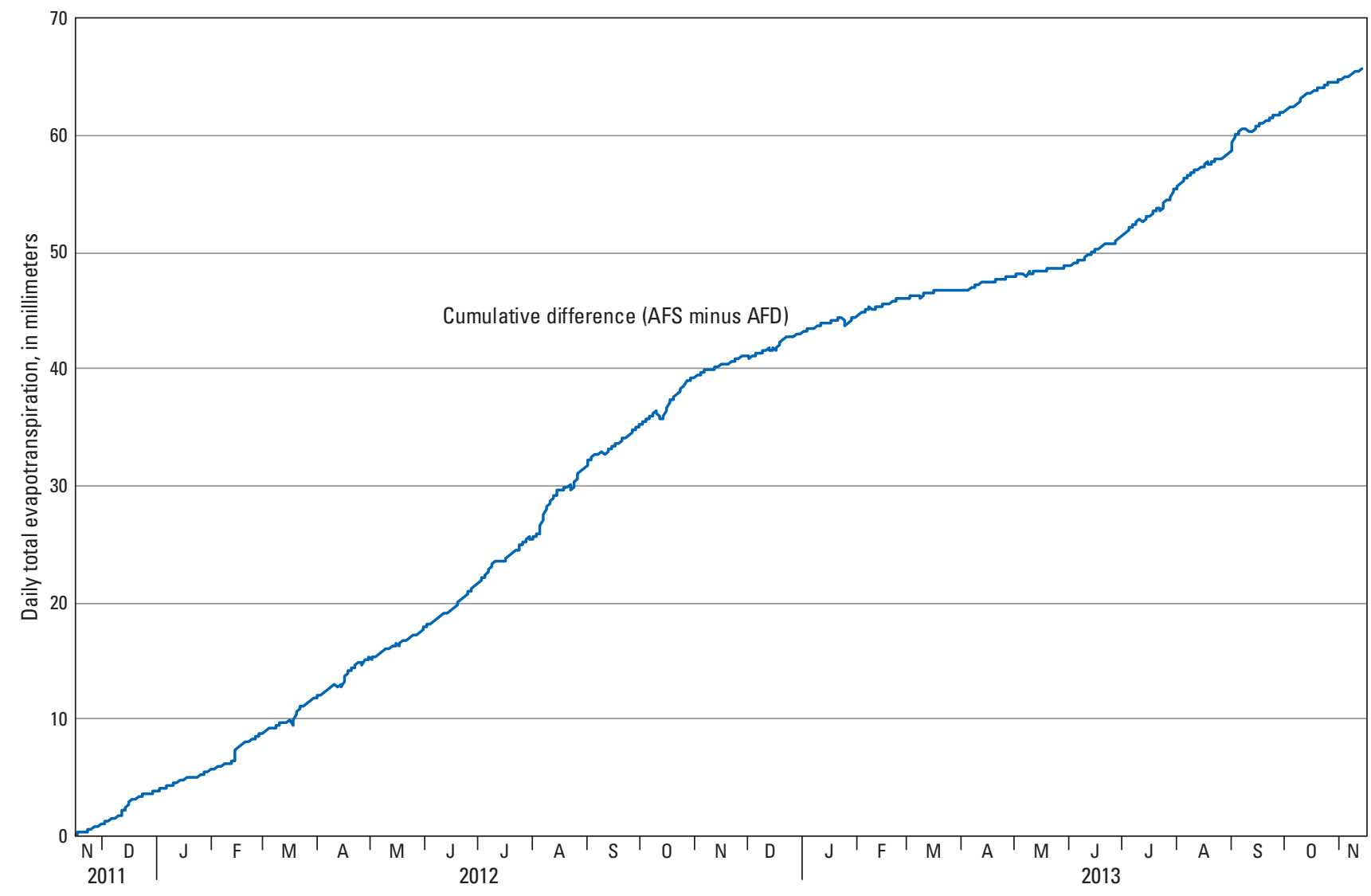

Figure 9. Cumulative difference in daily total evapotranspiration measured at Amargosa Flat Shallow (AFS) and Amargosa Flat Deep (AFD) sites, Amargosa Desert, Nye County, Nevada, November 15, 2011, to November 14, 2013.

saltgrass where the depth to water was about $3.7 \mathrm{~m}$ bls. However, no known measurements of GWET rates have been made at sites where depths to groundwater are similar to AFS.

In contrast to the AFS GWET results, $16 \mathrm{~mm}$ of GWET at AFD was not necessarily expected because shadscale is considered a xerophyte and its occurrence does not reliably infer shallow groundwater or groundwater discharge.

Nevertheless, it has been speculated that shadscale will use groundwater opportunistically (Nichols, 1994). Prior to this study, however, this process had not been directly investigated, and the results presented in sections, "Flow of Water in Unsaturated Soil" and "Stable Isotope Water Sourcing" show that groundwater was being lost through evapotranspirational processes and strongly support the upward flux of groundwater at this site (and AFS).

\section{Evapotranspiration Uncertainty}

Evapotranspiration measurement uncertainty was estimated by evaluating (1) the source area and fetch of each eddy-covariance station, (2) the energy-balance closure at each eddy-covariance station, and (3) a site-scale water balance at the ADRS. Estimated uncertainty is compared with literature values including those from other arid environments.

\section{Source Area and Fetch Considerations}

The source area contributing to the mean measured turbulent fluxes is the area from which the measured variables (water vapor and heat) originate. Turbulent-flux measurements can be conceptualized as weighted averages of the flux originating from a series of elemental surfaces that represent contributing areas upwind of the sensors. Source area characteristics are dependent upon the sensor height, surface roughness, and atmospheric stability. Lower eddy-covariance sensor heights, rougher surfaces, and unstable atmospheric conditions $(H>0)$ all reduce the turbulent-flux source area. The cumulative normalized contribution to the measured turbulent flux (cumulative normalized flux, or CNF) increases with distance from the sensors (Schuepp and others, 1990). The relative contribution of turbulent flux (also called the footprint) is zero at the sensor location, increases rapidly to a maximum at a relatively short distance upwind of the sensors, then decreases asymptotically with increasing distance from the sensors.

The ideal site placement for an eddy-covariance station is one where the terrain surrounding the site is flat and the 
fetch for the surface-of-interest is longer than the turbulentflux source area. Eddy-covariance sensors were positioned relatively low (2 m) at the Amargosa Flat sites specifically to minimize their source areas and limit any potential contributions from previously classified GWET areas, but were high enough above the vegetation to capture well-mixed conditions and avoid measurement artifacts from underlying heterogeneities (figs. 3, 4, and 5; Laczniak and others, 2001). An analytical model in the EdiRe processing program was used to quantify the CNF as a fraction of the turbulent flux originating within defined extents (Clement, 1999; Kormann and Meixner, 2000). The CNF was computed at each site for neutral and unstable conditions $(H \geq 0)$ at 25-, 50-, 75-, 100-, 200-, and 300-m fetch distances for the measurement period (table 10). Periods with stable conditions $(H<0)$ were excluded from this analysis because stable conditions typically occur at night when ET is minimal. The source areas were similar at all sites with a slightly larger footprint at AFS owing to the short vegetation height and corresponding lack of surface roughness (fig. 5). The source area mathematically extends to infinity, but because no measured surface is infinite, 50-, 75-, and 90-percent source areas contributing to a point flux measurement often are considered (Rannik and others, 2012). Assuming a 90 percent source area, the fetch at each site (about $200 \mathrm{~m}$ ) was adequate and eddy-covariance turbulent-flux measurements were representative of the surface-of-interest.

Table 10. Source area of turbulent-flux measurements at eddycovariance stations, Amargosa Desert, Nye County, Nevada, November 15, 2011, to November 14, 2013.

[Mean cumulative normalized flux: Footprint from 25 to 300 meters upwind of eddy-covariance sensors. Site name: AFS, Amargosa Flat Shallow site; AFD, Amargosa Flat Deep site; ADRS, Amargosa Desert Research Site]

\begin{tabular}{lcccccc}
\hline \multirow{2}{*}{$\begin{array}{c}\text { Site } \\
\text { name }\end{array}$} & \multicolumn{6}{c}{ Mean cumulative normalized flux } \\
\cline { 2 - 7 } & F25 & F50 & F75 & F100 & F200 & F300 \\
\hline AFS & 0.34 & 0.57 & 0.69 & 0.76 & 0.88 & 0.92 \\
AFD & 0.42 & 0.65 & 0.76 & 0.82 & 0.91 & 0.94 \\
ADRS & 0.43 & 0.67 & 0.77 & 0.83 & 0.92 & 0.95 \\
\hline
\end{tabular}

\section{Energy-Balance Closure}

The energy balance at the ADRS and Amargosa Flat sites was computed to assess the accuracy of eddy-covariance turbulent-flux $(L E+H)$ measurements. The energy balance is based on conservation of energy principles, and the degree to which energy-balance closure is achieved is quantified by the energy-balance ratio (EBR); notwithstanding, good energy-balance closure can result from offsetting erroneous measurements (Wilson and others, 2002):

$$
E B R=\frac{\sum L E+\sum H}{\sum R_{n}-\sum G}
$$

Ideally, if all energy fluxes are measured accurately (within the limits of measurement accuracy), then the $E B R$ will equal unity. In reality, eddy-covariance turbulent flux (eq. 14 numerator) is consistently less than the available energy (eq. 14 denominator). Wilson and others (2002) studied the results of other investigators and report $E B R$ values ranging from 0.39 to 1.69 for 50 site-years of data at 22 eddycovariance sites. Typical EBR values range from 0.6 to 1.0, but most frequently range from 0.7 to 0.8 , thus implying that on average $70-80$ percent of available energy is accounted for by their turbulent-flux measurements (Twine and others, 2000; Wilson and others, 2002; Foken, 2008). Resolving the so-called "energy imbalance problem," or balancing the turbulent energy against independently-measured available energy, is an active area of research. Various theories have been advanced by the scientific community to explain this discrepancy (Twine and others, 2000; Wilson and others, 2002; Foken, 2008; Foken and others, 2012; Leuning and others, 2012), but currently (2016) there is no consensus. The $E B R$ computed for each site in this study is AFS, 1.04; AFD, 0.85, ADRS, 0.88 (table 11).

A commonly applied remedy to close the energy balance is to force closure while maintaining the ratio between $L E$ and $H$ (the Bowen ratio) (Twine and others, 2000; Foken and others, 2012). To apply this method an investigator must have confidence that (1) available energy measurements are reasonably accurate, and (2) the "missing" turbulent flux can be estimated by assuming the missing $L E$ and $H$ are in proportion to the Bowen ratio (scalar similarity). However, there is evidence that this technique may not be applicable in all situations as a large part of the unclosed energy budget may be related to $H$ (Foken and others, 2012). Additionally, a drawback to the energy-balance method is $L E$ uncertainty cannot be assessed independently. 
Table 11. Mean daily energy-balance data, Amargosa Desert, Nye County, Nevada, November 15, 2011, to November 14, 2013.

\begin{tabular}{|c|c|c|c|c|c|c|c|c|}
\hline $\begin{array}{c}\text { Site } \\
\text { name }\end{array}$ & $\begin{array}{c}R_{n} \\
\left(\mathbf{W} / \mathbf{m}^{2}\right)\end{array}$ & $\begin{array}{c}G \\
\left(W / m^{2}\right)\end{array}$ & $\begin{array}{c}\text { Available } \\
\text { energy } \\
\left(\mathrm{W} / \mathrm{m}^{2}\right)\end{array}$ & $\begin{array}{c}L E \\
\left(W / \mathbf{m}^{2}\right)\end{array}$ & $\begin{array}{c}H \\
\left(\mathrm{~W} / \mathrm{m}^{2}\right)\end{array}$ & $\begin{array}{c}\text { Turbulent } \\
\text { flux } \\
\left(\mathbf{W} / \mathbf{m}^{2}\right)\end{array}$ & $\begin{array}{c}\text { Bowen } \\
\text { ratio } \\
\text { (unitless) }\end{array}$ & $\begin{array}{c}E B R \\
\text { (unitless) }\end{array}$ \\
\hline AFS & 34.09 & 2.21 & 31.88 & 10.40 & 22.85 & 33.25 & 2.2 & 1.04 \\
\hline AFD & 63.62 & -0.43 & 64.05 & 7.86 & 46.36 & 54.22 & 5.9 & 0.85 \\
\hline ADRS & 69.92 & 0.78 & 69.14 & 6.43 & 54.49 & 60.92 & 8.5 & 0.88 \\
\hline
\end{tabular}

To evaluate scalar similarity and to explicitly assess $E T(L E)$ accuracy, a water balance was computed at the ADRS using equation 13 . One reason that the ADRS was selected as the control site for this study is the groundwater contribution to total ET was assumed to be $0 \mathrm{~mm} / \mathrm{yr}$ because the thick unsaturated zone (about $110 \mathrm{~m}$ ) inhibits the upward movement of groundwater from the saturated zone to land surface. This assumption is supported by multiple lines of data and modeling (for example, Walvoord and others, 2004). Another factor that may affect measured ET is episodic changes in water stored in the upper part of the thick unsaturated zone (just below the root zone). For example, ADRS studies have shown that soil drying below the root zone can be induced by extended periods of extremely low precipitation ( $<15$ mm/yr) (Andraski, 1997; Garcia and others, 2011). However, the meteorological conditions for the years prior to and during this study were not conducive to such deep drying. Therefore, precipitation is assumed to be the only known water source and total ET should equal $P$. The result of this analysis indicates that mean annual total ET (83 mm/yr) exceeded mean annual $P(73 \mathrm{~mm} / \mathrm{yr})$ by 13.7 percent $(10 \mathrm{~mm} / \mathrm{yr})$; therefore, $E T(L E)$ at ADRS is overestimated by 13.7 percent compared to $P$ based on equation 13 , and turbulent fluxes $(L E+H)$ are underestimated by 13.1 percent compared to the available energy based on equation 14. Assuming that available energy measurements are accurate, this discrepancy indicates that the lack of energy-balance closure at ADRS may be attributed to $H$. Based on the conflicting energy- and water-balance results, no data adjustments were made based on energy-balance closure. Additional work is needed to investigate other factors that could contribute to the apparent discrepancy between cumulative precipitation and ET measured in arid-xeric ecosystems with deep unsaturated zones, but such research was beyond the scope of this study.

The good $E B R$ values attained for this study indicate generally acceptable accuracy for turbulent-flux and available-energy measurements. Turbulent-flux and availableenergy measurement uncertainties commonly are estimated as 10 percent because the complicated algorithms of the eddy-covariance method do not allow for the determination of errors according to error propagation law (Twine and others, 2000; Foken, 2008; Foken and others, 2012). Assuming 10 percent uncertainty in turbulent-flux and available-energy measurements, the margins of error overlap at each site. The overlapping margins of error indicate that these measurements are consistent with conservation of energy principles (Taylor, 1997).

Based on the $E T(L E)$ evaluation, uncertainty is estimated to be 15 percent. This uncertainty estimate is considered reasonable and is consistent with previous studies in arid environments. The similar but offsetting magnitudes of water (13.7 percent) and energy (-13.1 percent) imbalances at ADRS are within the overall accuracy reported by Kampf and others (2005) and Garcia and others (2014). Kampf and others (2005) estimated an overall accuracy of 15 percent based on measurements from an area receiving only $20 \mathrm{~mm}$ of precipitation annually. Similarly, Garcia and others (2014) estimated an overall accuracy of 16 percent for playa evaporation measurements in an area that received an average of $152 \mathrm{~mm}$ of precipitation over a 2-year period. The uncertainties estimated for this study and the studies by Kampf and others (2005) and Garcia and others (2014) are at the upper end of the 10-15 percent accuracy range reported by Foken and others (2012).

Groundwater evapotranspiration uncertainty at AFS and AFD was estimated by propagating $E T$ and $P$ uncertainties "in quadrature" (the square root of the sum of $E T$ and $P$ uncertainties squared) (table 9). The computed annual GWET at AFS of $50 \mathrm{~mm}$ is well outside of the estimated uncertainty of $\pm 20 \mathrm{~mm}$. The annual GWET rate estimated for AFD $(16 \pm 15 \mathrm{~mm})$ has relatively high uncertainty, but the upward flux of groundwater at this site is strongly supported by results presented in the remaining sections of this report. 


\section{Groundwater-Level Fluctuations}

Groundwater levels in discharge areas of the western United States typically decline each growing season when phreatophytes withdraw groundwater and outflow from the aquifer exceeds inflow, and rise after each growing season when phreatophytes are quiescent and inflow exceeds outflow (White, 1932; Laczniak and others, 1999; Fenelon and Moreo, 2002). This characteristic annual water-level fluctuation pattern was observed in the AFS and AFD monitoring wells. Daily mean water levels computed from continuous (hourly) pressure measurements are shown in figure 10. Annual depthto-groundwater minima occurred on April 18, 2012 (1.38 m bls) and April 8, 2013 (1.36 m bls) at AFS, and April 14, 2012 (1.51 m bls) and April 8, 2013 (1.48 m bls) at AFD. Annual depth-to groundwater maxima occurred on October 4, 2012 (1.78 m bls) and September 27, 2013 (1.80 m bls) at AFS, and September 27, 2012 (1.80 m bls) and September 7, 2013 ( $1.86 \mathrm{~m}$ bls) at AFD. Annual fluctuation magnitudes were $0.40 \mathrm{~m}$ in 2012 and $0.44 \mathrm{~m}$ in 2013 at AFS, and $0.29 \mathrm{~m}$ in 2012 and $0.38 \mathrm{~m}$ in 2013 at AFD.
The timing of minimum and maximum depths to groundwater at AFS and AFD were similar to wells in Ash Meadows (Laczniak and others, 1999). Although the timing of annual fluctuations were similar, fluctuation magnitudes were substantially smaller for the Amargosa Flat wells than for wells in Ash Meadows. Annual water-level fluctuation magnitudes in 28 wells in Ash Meadows that were distant from surface-water sources ranged from 0.64 to $3.11 \mathrm{~m}$ with a mean of $1.64 \mathrm{~m}$; therefore, the mean annual fluctuation in Ash Meadows wells was about 4.3 times greater than the mean annual fluctuation in AFS and AFD (0.38 m).

Superimposed on annual water-level fluctuations were short-term responses to local precipitation (fig. 10). Seasonal water-level declines that began in April 2012 at AFS (3.3 mm/d) and AFD (2.6 mm/d) were interrupted by two precipitation periods - a $39 \mathrm{~mm}$ storm on August 3, 2012 that caused water levels to rise $57 \mathrm{~mm}$ at AFS and $30 \mathrm{~mm}$ at AFD during the 6 subsequent days, and a $13 \mathrm{~mm}$ storm on August 22, 2012 that caused water levels to rise $12 \mathrm{~mm}$ at AFS and $10 \mathrm{~mm}$ at AFD during the 3 subsequent days. As a result, 2012 annual maxima were not as deep as 2013. Water levels began to rise following the annual trough and responded to a

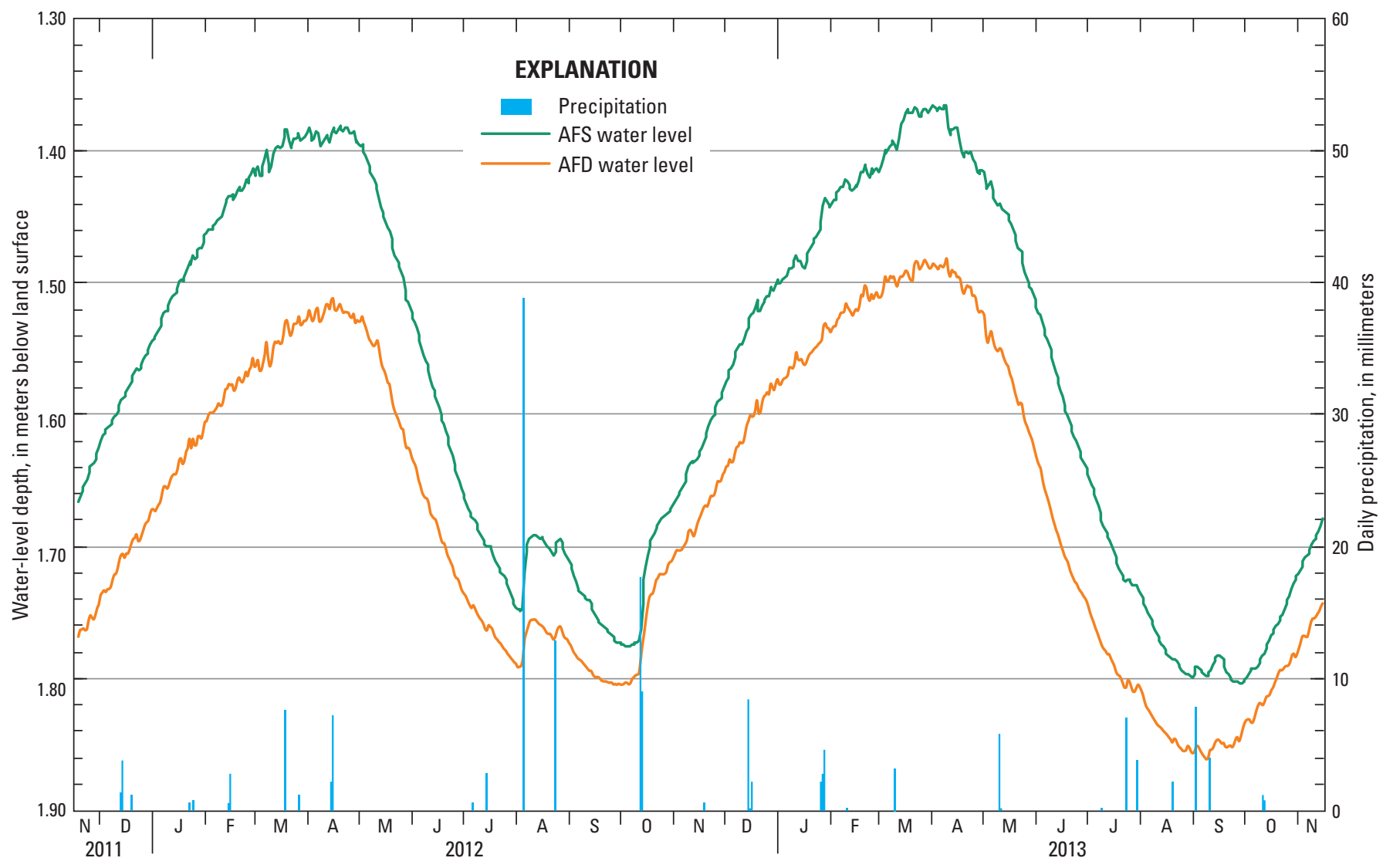

Figure 10. Water-level depth and daily precipitation at Amargosa Flat Shallow (AFS) and Amargosa Flat Deep (AFD) sites, Amargosa Desert, Nye County, Nevada, November 15, 2011, to November 14, 2013. 
$27 \mathrm{~mm}$ precipitation event on October 10-11, 2012 by rising $57 \mathrm{~mm}$ at AFS and $39 \mathrm{~mm}$ at AFD during the 3 subsequent days. These water-level rise rates were substantially greater than the mean rise rates, which from mid-November 2011 to mid-April 2012 were $1.9 \mathrm{~mm} / \mathrm{d}$ at AFS and $1.7 \mathrm{~mm} / \mathrm{d}$ at AFD. Numerous additional albeit smaller water-level responses to relatively minor precipitation periods were recorded in 2013. Previous work in Ash Meadows also noted that shortterm water-level responses to precipitation events typically attenuated in 2 weeks or less (Laczniak and others, 1999; Fenelon and Moreo, 2002).

Daily fluctuations in response to ET stress were clearly evident beginning in mid-May and continuing through early October. Water levels at AFS generally began declining in the morning, declined throughout much of the day, and then remained steady overnight. This daily cycle repeated throughout the growing season with mid-season daytime declines being the longest. A 6-day record for July 2012 is shown in figure 11. From July 24 to 29, 2012, the daily waterlevel fluctuation at AFS ranged from 3.5 to $4.2 \mathrm{~mm} / \mathrm{d}$ with a mean of $4.1 \mathrm{~mm} / \mathrm{d}$, and the total water-level decline for the 6-day period was $22.1 \mathrm{~mm}$. Daily fluctuation magnitudes at AFD during the same period were similar to AFS ranging from 2.7 to $3.8 \mathrm{~mm} / \mathrm{d}$ with a mean of $3.3 \mathrm{~mm} / \mathrm{d}$. However, the total water-level decline at AFD $(8.6 \mathrm{~mm})$ was less than onehalf the decline at AFS. Minimal or no water-level recovery (rise) was apparent at AFS, whereas a pronounced recovery was evident at AFD. The greater rate of water-level decline at AFS corresponded with a greater ET rate at AFS compared to AFD (fig. 11).

Water levels typically respond to ET stress by declining throughout the day and recovering at night (White, 1932). This daily pattern was not observed at AFS as there was no nighttime recovery (indicating that drawdown resulting from daily ET stresses cannot be recovered overnight at this time of year), nor was it observed at AFD, where daily maximum water-level depths occurred during early morning instead of early evening (indicating that daily fluctuations were out of phase with daily ET). This lag in water-level response to ET stress may be attributed to the relatively greater depth to groundwater at AFD. Because the ability of soil to transmit water declines rapidly with increasing soil dryness and increasing depth to the subsurface water source, a lag can occur when groundwater flux through the unsaturated zone is insufficient to meet ET demand. Laczniak and others (1999, p. 43) noted a similar lag in water-level response to ET stress.

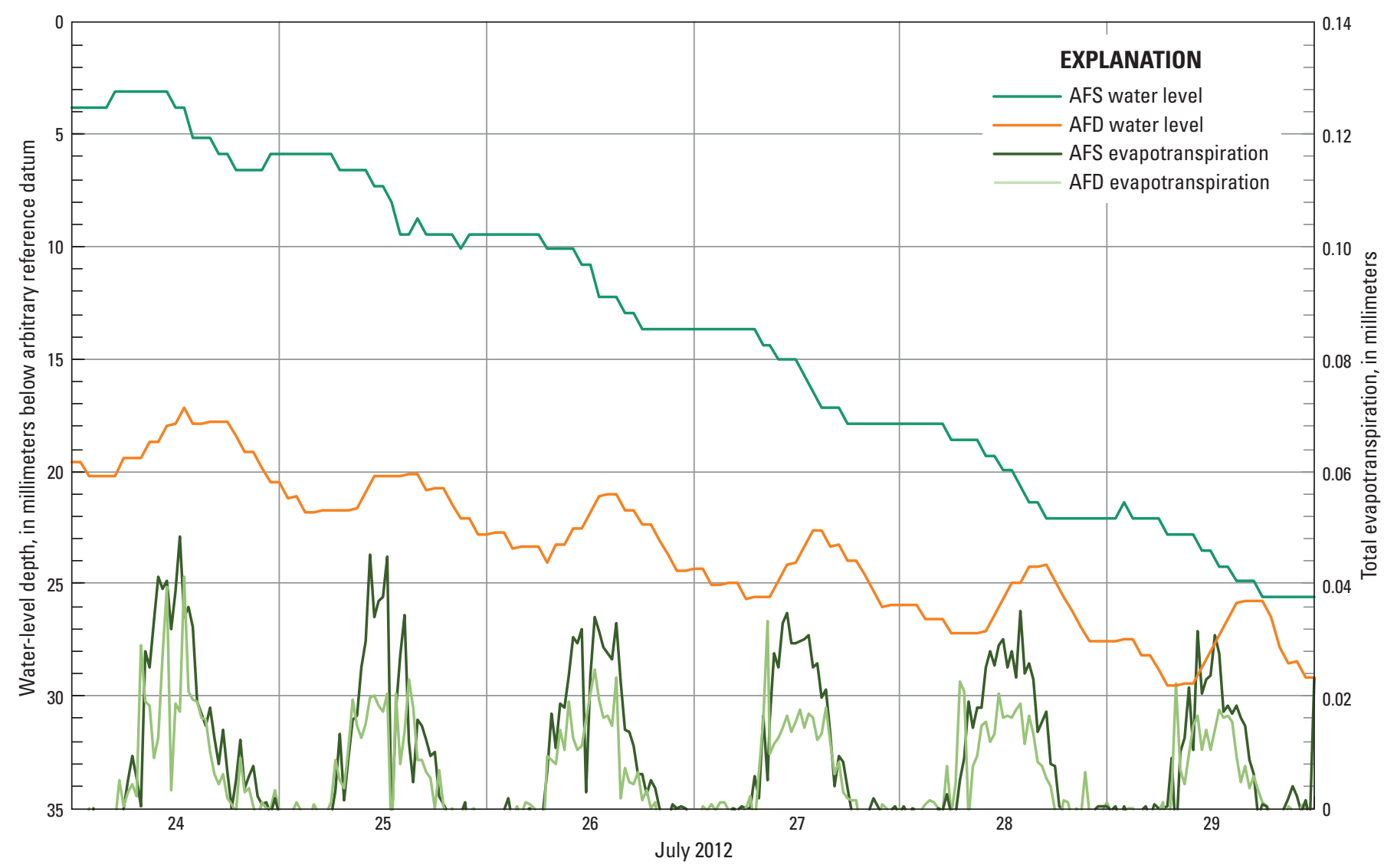

Figure 11. Water-level depth and evapotranspiration, Amargosa Flat Shallow (AFS) and Amargosa Flat Deep (AFD) sites, Amargosa Desert, Nye County, Nevada, July 24-29, 2012. 
The mean daily fluctuation magnitudes from July 24-29, 2012 for AFS (4.1 mm/d) and AFD (3.3 mm/d) were typically much smaller than those observed at nearly every well in Ash Meadows, which ranged from less than 15 to about $90 \mathrm{~mm} / \mathrm{d}$ (Laczniak and others, 1999).

Numerous additional observations can be made based on water-level fluctuations to characterize the shallow confined unit tapped by AFS and AFD monitoring wells:

1. The lag time between the $39 \mathrm{~mm}$ of rainfall recorded between 1630 and 1800 on August 3, 2012 and the water-level response in AFS and AFD was less than 2 hours. This lag time includes two components: (1) the time necessary for precipitation to travel through the unsaturated zone and enter the groundwater system and (2) the time necessary for changes in hydraulic head in the recharge area to be observed in each well as a pressure response in a confined unit (Fenelon and Moreo, 2002). The almost instantaneous pressure responses for AFS and AFD can be explained if (1) the travel time through the unsaturated zone was short, which is possible if transport is through coarse-grained sediments and depth to groundwater is shallow, and (2) the recharge area was in close proximity to the wells. Given these physical constraints, the most likely point of recharge was in the wash approximately $500 \mathrm{~m}$ south of AFS and $620 \mathrm{~m}$ southwest of AFD (fig. 4).

2. The quick pressure responses to local precipitation indicate that the areal extent of the local confining layer is limited.

3. Short-lived and sporadic local recharge periods are superimposed on regional recharge from the Spring Mountains.

Based on depth to the saturated zone (AFS, $3.8 \mathrm{~m}$; AFD, $5.3 \mathrm{~m}$; table 7) and the water-level-fluctuation results, the following can be inferred regarding the GWET rates computed for AFS (50 mm/yr) and AFD (16 mm/yr) (table 9):

1. The relatively small annual and daily water-level fluctuation magnitudes at Amargosa Flat compared to the primary discharge area in Ash Meadows provides support for the comparatively small computed GWET rates.

2. Although daily mean water levels for AFS and AFD were highly correlated $(r=0.98)$, the steeper annual decline and recovery at AFS compared to AFD (fig. 10) provides support for a GWET rate at AFS that was about 3 times greater than at AFD.

3. The difference between AFS and AFD GWET rates also may be related to depth-to-groundwater effects on the associated groundwater flux through the unsaturated zone.

The factors and processes controlling water fluxes between the saturated zone and land surface (fig. 2), and their associated effects on GWET were further analyzed.

\section{Flow of Water in Unsaturated Soil}

Unsaturated-zone laboratory-analysis, field-monitoring, and water-flux-estimation results are used to characterize soil properties and evaluate processes influencing the direction and magnitude of water movement between the land surface and groundwater at the AFS and AFD sites. The information also was used to make relative comparisons between the Amargosa Flat and ADRS control-site results.

\section{Soil Properties and Long-Term Processes Affecting Water Flow}

The soil particle-size distribution can have a strong effect on the rate of water transport, the amount of water held in the soil, and the amount of water available to plants. Sieve analyses of near-surface $(0-0.15 \mathrm{~m})$ soil showed that gravel content was relatively low for both AFS (5 percent) and AFD (10 percent), and gravel was absent at greater depths (Moreo and others, 2017). The less than $2 \mathrm{~mm}$ particlesize distributions for the Amargosa Flat profiles are shown in figure 12. The AFS and AFD profiles are both broadly classified as fine textured because they contain large quantities of silt and clay. For example, the silt plus clay content for AFS ranged from 56 to 100 percent and that for AFD ranged from 54 to 100 percent. In strong contrast to the Amargosa Flat profiles, the ADRS profile (upper $5 \mathrm{~m}$ ) is broadly classified as coarse textured due to its high sand content (approximately 75-95 percent) and its gravel content is also high (approximately 20-65 percent) (Andraski, 1996).

The laboratory-measured saturated hydraulicconductivity values (fig. 13) show substantial differences between and within sites, but the differences are not completely explained by an evaluation of the particle-size data alone. For example, saturated hydraulic-conductivities for the upper $1 \mathrm{~m}$ of the profiles show that AFD values were 2 orders of magnitude greater than those for AFS, even though the soil particle-size distributions were similar-that is, sand, silt, and clay differed by less than or equal to 5 percent on average (fig. 12). The greater upper-profile conductivities for AFD are attributed to increased biological activity and soil structural-aggregate development which, in turn, contribute to the formation of macropores and enhanced water transport under saturated conditions. In contrast, inspection of soilsample pit walls at AFS indicated that root development primarily occurred in the upper $0.15 \mathrm{~m}$ and relatively little macropore formation was observed at greater depths. The highest saturated hydraulic-conductivities were measured for the two deepest AFS samples, which were collected just above and below the top of the saturated zone (3.5-4.2 $\times$ $10^{-4} \mathrm{~cm} / \mathrm{s}$; fig. 13). The 3.56-m depth unsaturated-zone sample was from a hard-soil layer (about 3.1-3.8 m deep) that may have been fractured by core sampling, causing an artificially high saturated-hydraulic conductivity. The 4.10-m depth sample was from a core that was visibly waterlogged 

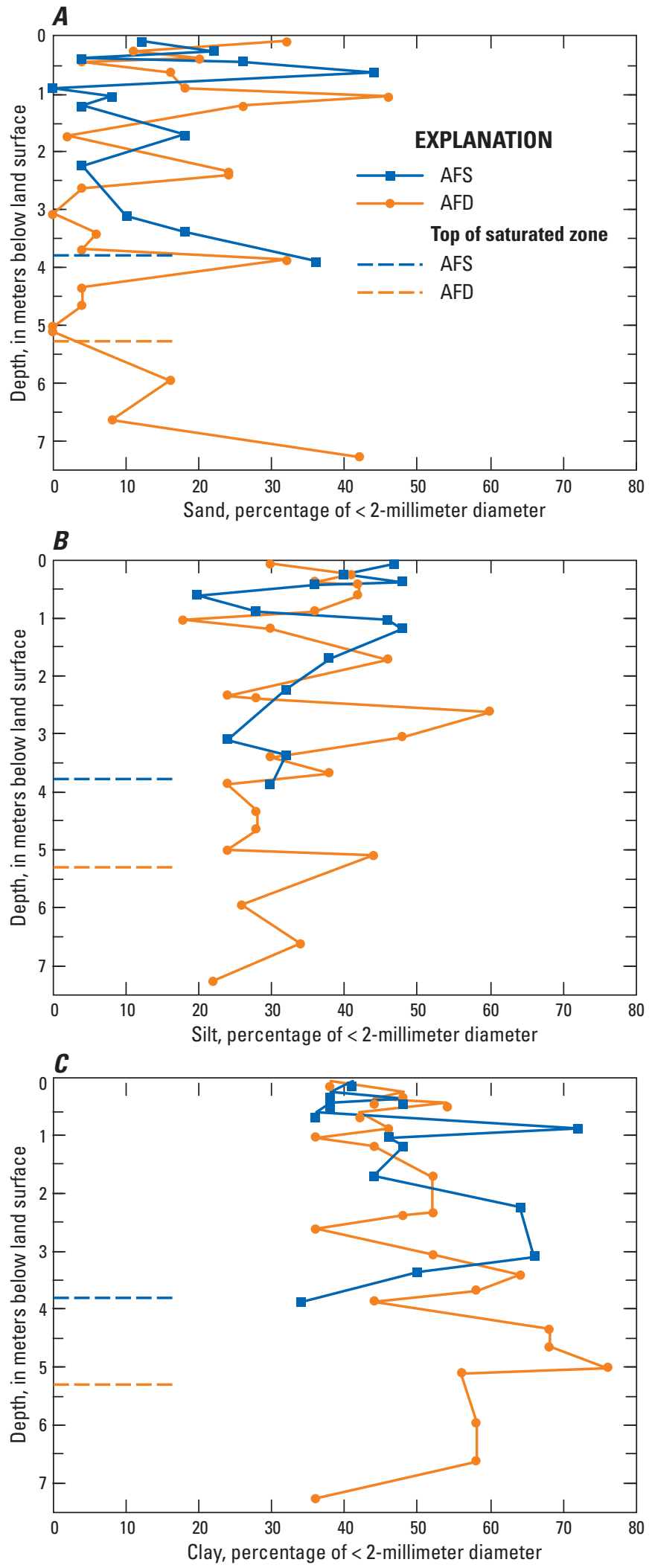

Figure 12. Soil profile variations in particle-size distribution determined using cores collected at the beginning of the study for $(A)$ sand 0.05-2 millimeters, $(B)$ silt 0.002-0.05 millimeters, and $(C)$ clay less than $(<) 0.002$ millimeters for the Amargosa Flat Shallow (AFS) and Amargosa Flat Deep (AFD) sites, Amargosa Desert, Nye County, Nevada, November 2011. at the time of collection and its high saturated-hydraulic conductivity corresponded with an interval of increasing sand and decreasing clay contents (figs. 12A and 12C). At the other extreme, the lowest conductivity values for AFS and AFD were all on the order of $10^{-7} \mathrm{~cm} / \mathrm{s}$ (fig. 13). These samples indicated that, in addition to the biological, soil-development, and soil-texture effects, clay mineralogy and the associated potential to swell upon wetting had a strong influence on the lowest conductivities measured for the two soil profiles. When a clay swells the total porosity and the volume of water is held in the soil, both increase; however, the increase in total porosity results from an increase in the number of smaller pores and a concomitant decrease in the number of larger water-transmitting pores, which leads to a sharp reduction in the saturated hydraulic conductivity (Koorevaar and others, 1983).

Clay mineralogy was not determined in this study, but the apparent effects of clay swelling on gravimetric soil-water content can be illustrated using laboratory data collected under saturated conditions. A subset of gravimetric soil-water retention data is shown in figure 14 for samples from both the shallow non-swelling and deeper swelling parts of the AFS and AFD profiles (see Moreo and others [2017] for complete data set). At saturation (water potential $=0 \mathrm{MPa}$ ), the AFS shallow-sample water contents $(0.65-0.73 \mathrm{~g} / \mathrm{g}$; figs. $14 \mathrm{~A}$ and $14 B$ ) are about two times less than those for the deeper swelling-clay samples (1.21-1.79 g/g; figs. $14 C$ and $14 D$ ). Similar AFD profile comparisons show the shallow-sample water contents (0.42-0.54 g/g; figs. $14 E$ and $14 F)$ are about three times less than those for the deeper swelling-clay samples (1.37-1.65 g/g; figs. $14 G$ and $14 H$ ). The range of gravimetric soil-water contents measured for the swelling clay Amargosa Flat samples is similar to those reported for other swelling-clay soils (Bruand and Tessier, 2000; Ardiansyah and others, 2008).

Volumetric soil-water retention data and calculated hydraulic-property functions for shallow-depth AFS and AFD samples are shown in figure 15. The deeper swellingclay samples were not included in this characterization because the bulk-soil volume varied to an unknown degree as the soil swelled and shrank under laboratory wetting and drying conditions, respectively. The soil-water retention functions (figs. 15A-15D) and the isothermal-liquid $\left(K_{L i}\right)$, isothermal-vapor $\left(K_{V i}\right)$, and thermal-vapor $\left(K_{V t}\right)$ conductivity functions (figs. 15E-15H) cover the full range of soilmoisture conditions from saturated to dry. At saturation (water potential $=0 \mathrm{MPa}$ ), where the measured volumetric-water content is equivalent to the total porosity, the AFS shallowcore water contents $\left(0.62-0.80 \mathrm{~cm}^{3} / \mathrm{cm}^{3}\right.$; figs. $\left.15 A-15 B\right)$ are somewhat greater than those for the AFD shallow cores $\left(0.48-0.61 \mathrm{~cm}^{3} / \mathrm{cm}^{3}\right.$; figs. $\left.15 C-15 D\right)$. The fitted soil-water retention function and the calculated conductivity functions for isothermal liquid, isothermal vapor, and thermal vapor were calculated using equations 8,9 , and 10 . At and near saturation, the isothermal liquid conductivity for the AFS soil $\left(10^{-6} \mathrm{~cm} / \mathrm{s}\right.$; figs. $\left.15 \mathrm{E}-15 \mathrm{~F}\right)$ are about 100 times less than those for the AFD soil $\left(10^{-4} \mathrm{~cm} / \mathrm{s}\right.$; figs. $\left.15 G-15 H\right)$. 


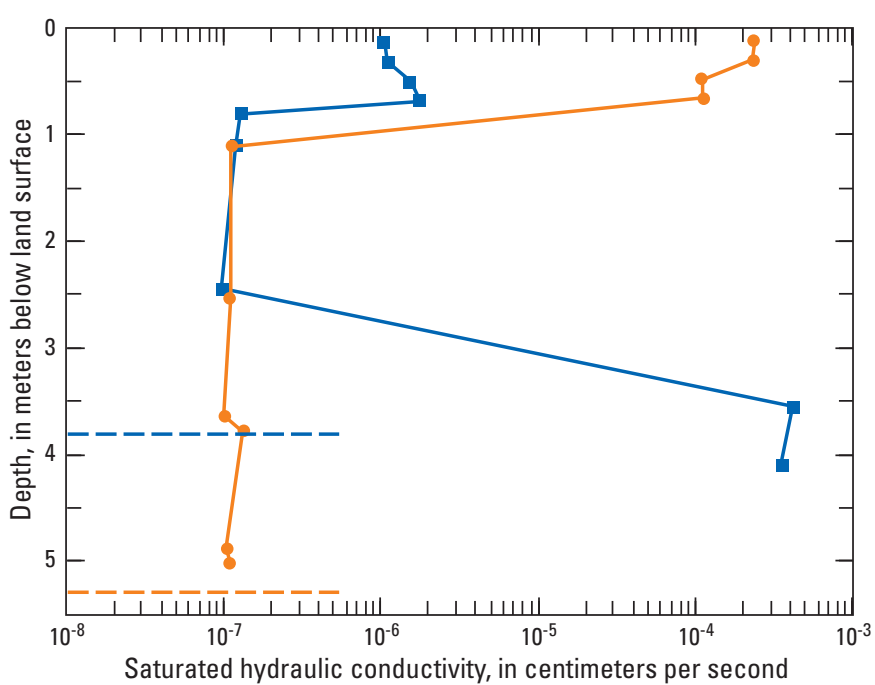

EXPLANATION

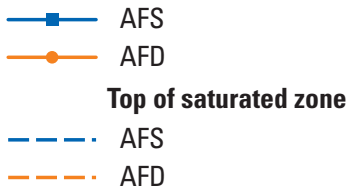

Figure 13. Soil profile variations in saturated hydraulic conductivity determined using cores collected at the beginning of the study at Amargosa Flat Shallow (AFS) and Amargosa Flat Deep (AFD) sites, Amargosa Desert, Nye County, Nevada, November 2011.

In contrast to the Amargosa Flat sites, the ADRS coarsetextured profile has much lower saturated soil-water contents range $\left(0.17-0.29 \mathrm{~cm}^{3} / \mathrm{cm}^{3}\right)$ and higher saturated-hydraulic conductivities range $\left(10^{-4}-10^{-2} \mathrm{~cm} / \mathrm{s}\right)$ (Andraski, 1996).

Figure 15 illustrates the complexity of unsaturated flow calculations because, in addition to the need to account for each of the three flow components, the individual componentconductivities change substantially in response to changing soil-moisture conditions. The isothermal-liquid conductivity $\left(K_{L i}\right)$ consistently decreases as the soil becomes drier, but the isothermal-vapor conductivity $\left(K_{V i}\right)$ and the thermal-vapor conductivity $\left(K_{V t}\right)$ first increase as the water-filled pores drain and air-filled porosity increases, and then decrease as soilwater potential decreases with further soil drying. A relative comparison between the Amargosa Flat sites and the ADRS shows that the approximate maximum liquid conductivities for AFS $\left(K_{L i} 10^{-6} \mathrm{~cm} / \mathrm{s}\right)$ and AFD $\left(K_{L i} 10^{-4} \mathrm{~cm} / \mathrm{s}\right)$ were lower on average than those for the ADRS $\left(K_{L i}\right.$ about $10^{-4}$ to $\left.10^{-2} \mathrm{~cm} / \mathrm{s}\right)$, and the approximate maximum vapor-conductivities for AFS and AFD were on the same order as those for the ADRS $\left(K_{V i} 10^{-13} \mathrm{~cm} / \mathrm{s} ; K_{V t}\right.$ at $20^{\circ} \mathrm{C} 10^{-7} \mathrm{~cm} / \mathrm{s}$ ) (Andraski and Jacobson, 2000). Additional information about the Amargosa Flat hydraulic-property characterization results is given in the section, "Soil-Water Fluxes."
Chloride-concentration and water-potential measurements at the Amargosa Flat sites were used to infer long-term processes controlling the infiltration (entry) and percolation (downward movement) of liquid water in the soil profiles. Several deep unsaturated-zone studies in interdrainage areas of arid alluvial basins in the southwestern United States (including ADRS) have used this approach to quantify water fluxes on millennial timescales (for example, Tyler and others, 1996; Andraski and Prudic, 1997; Walvoord and others, 2002; Scanlon and others, 2003; Stonestrom and others, 2003; Walvoord and others, 2004). A brief overview of findings from these previous studies is given to provide a benchmark against which to compare the Amargosa Flat results. The studies have documented a characteristic bulge-shaped pattern in the chloride-concentration profile beneath native vegetation that is interpreted as representing the accumulation of chloride since the late Pleistocene $(10,000-15,000$ years ago), when a major change in climate occurred. This change from cooler-and-wetter to hotter-anddrier conditions and the associated transition from mesic to xeric vegetation led to the minimization of deep percolation of precipitation and the ongoing buildup of chloride below the active near-surface percolation zone. Beneath the chloride bulge, the concentrations become uniformly low; this is attributed to paleohydrologic conditions that once supported deep percolation and the flushing of chloride from the unsaturated zone.

The AFD chloride profile shows the classic single bulgeshaped pattern (fig. 16A) observed at multiple xeric-vegetation sites in the southwestern United States. Specific features of the AFD profile include little chloride in the upper $1 \mathrm{~m}$ bls, followed by increased chloride in the 1- to 3.6-m depth accumulation zone, followed by little additional chloride at greater depths. The lower concentrations in the upper $1 \mathrm{~m}$ bls correspond with dynamic near-surface processes whereby episodic infiltration and percolation of precipitation flush chloride downward by advective-liquid transport before the precipitation is released back to the atmosphere by ET. The sharp peak in chloride concentration $(112 \mathrm{mg} / \mathrm{kg})$ at the 1-m depth occurs because virtually all of the liquid water transporting chloride through the overlying soil is returned to the atmosphere as water vapor on a seasonal or annual basis, but the chloride is left behind because it cannot be transported in the vapor phase. Beneath the dynamic near-surface zone, the gradual decrease in chloride concentrations below the peak indicates chloride is continuing to move slowly downward, but in the absence of advective-liquid transport, this movement is attributed to diffusional transport that is driven by chlorideconcentration gradients. Beneath the accumulation zone, the concentrations become uniformly low $(0.88 \pm 0.25 \mathrm{mg} / \mathrm{kg})$.

The AFD soil-water potential and soil-water content profiles shown in figures $16 B$ and $16 C$ provide complementary data and strong support for longer-term flow and transport processes inferred from the chloride data. For example, in the upper $1 \mathrm{~m}$ of the profile the low soil-water potentials ( -107 to $-4.4 \mathrm{MPa}$ ) indicate dry soil and the downward increase in 
A. AFS 0.14-0.15 m depth

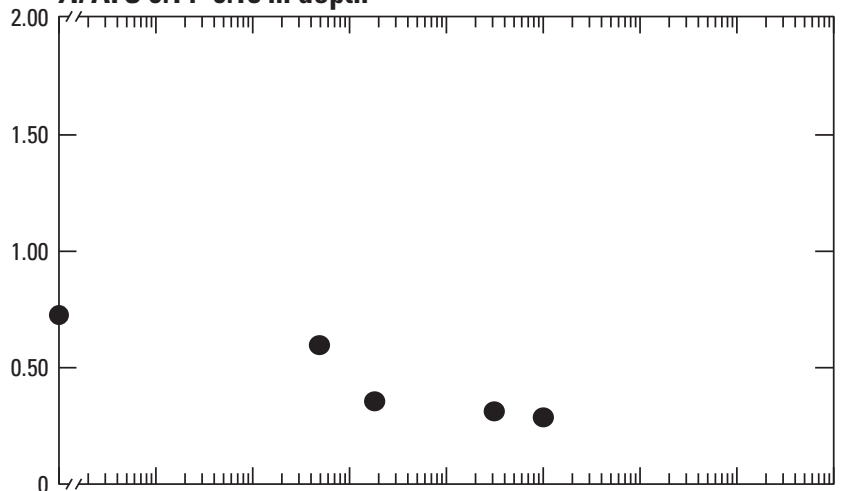

B. AFS $0.50-0.51 \mathrm{~m}$ depth

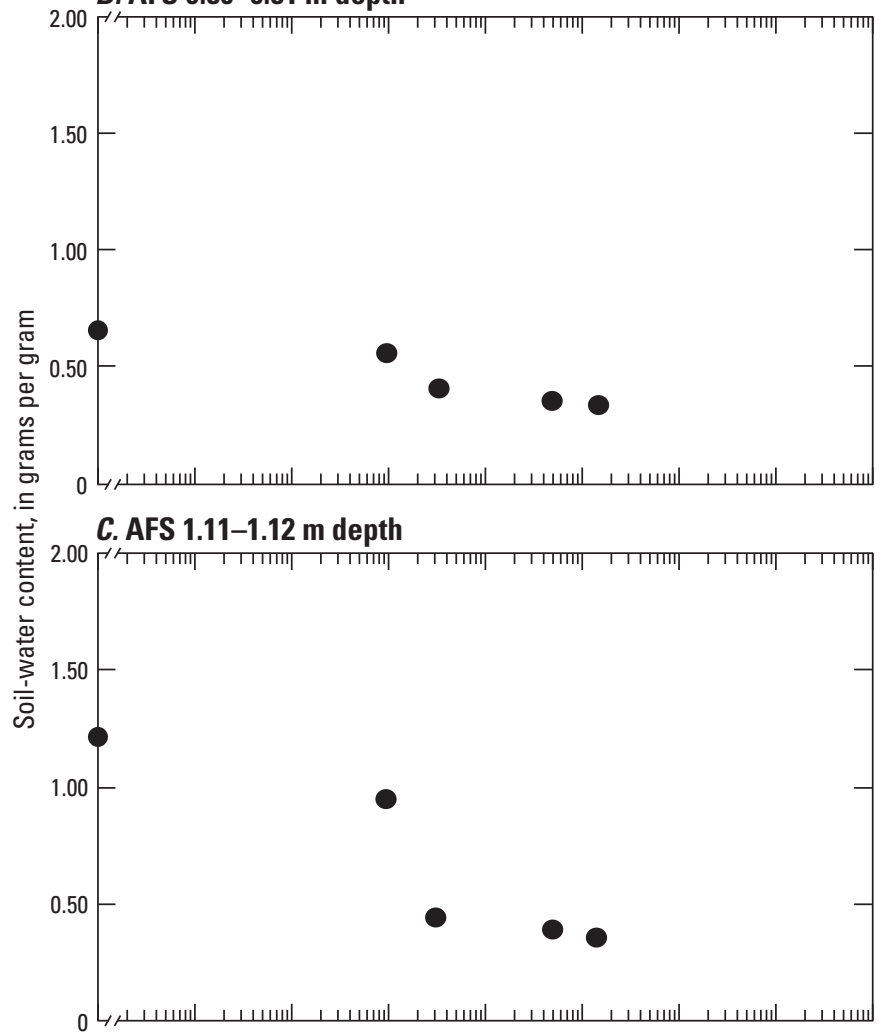

D. AFS 2.42-2.47 m depth

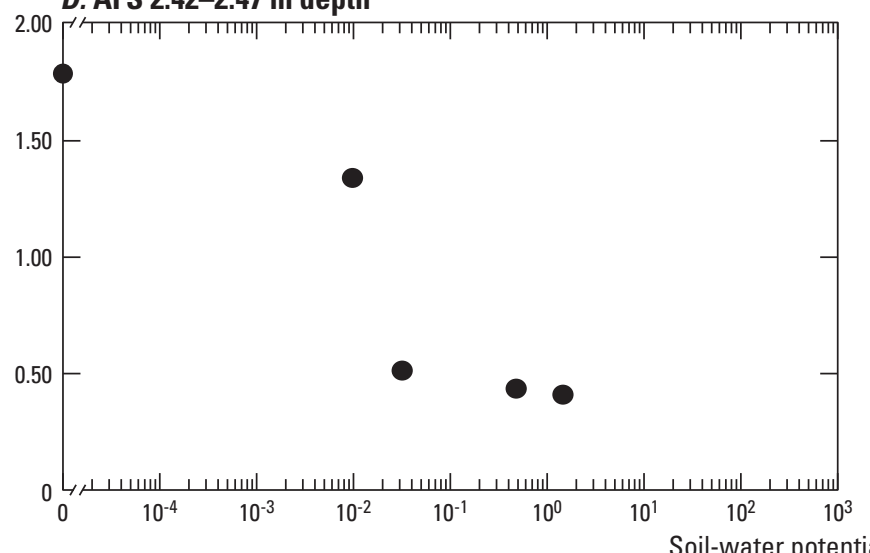

E. AFD 0.10-0.15 m depth

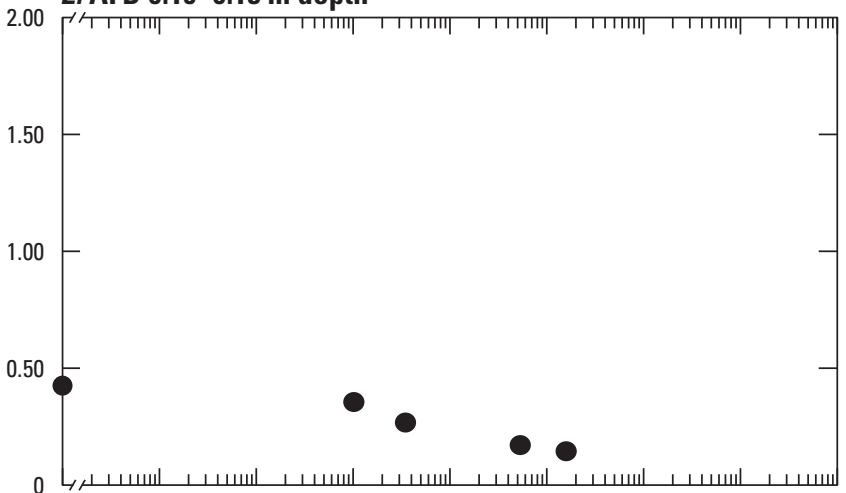

F. AFD 0.46-0.51 m depth

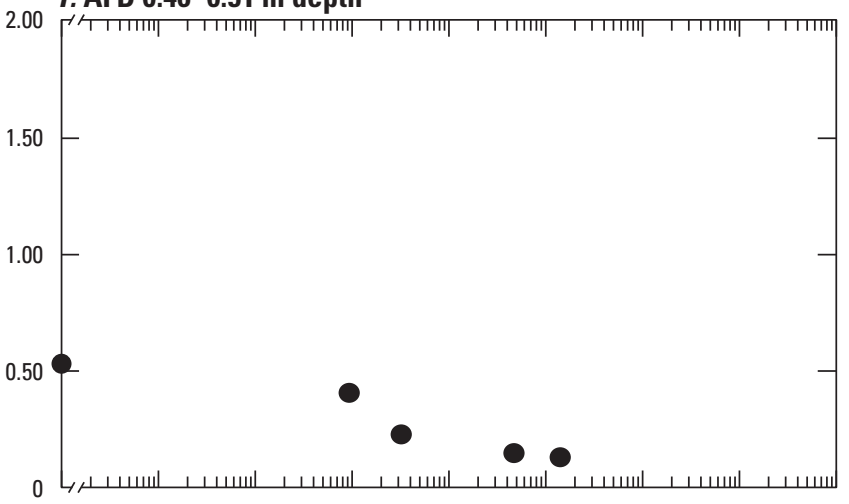

G. AFD 1.11-1.12 m depth

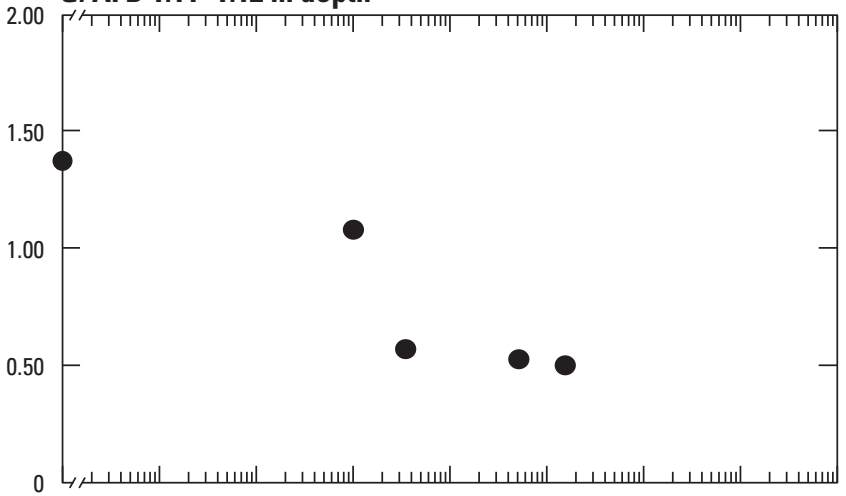

H. AFD 2.53-2.54 m depth

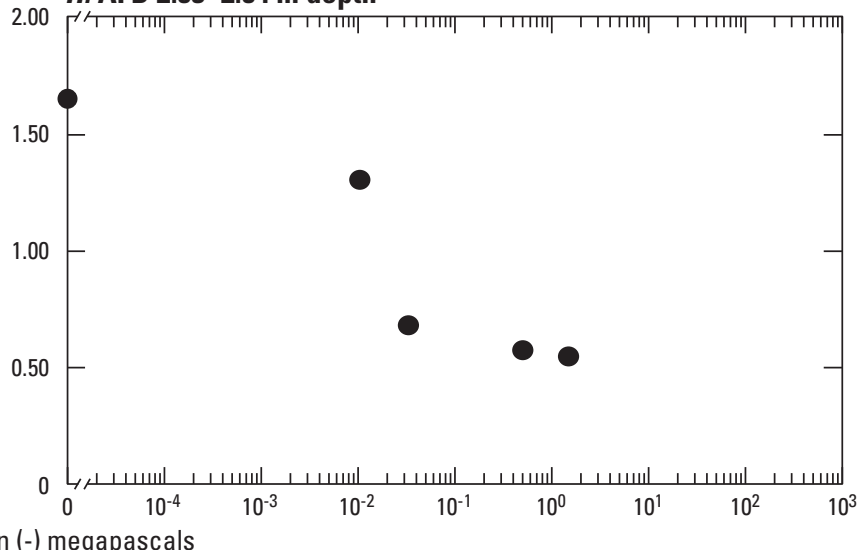

Figure 14. Gravimetric soil-water retention data for selected depths from samples collected at the beginning of the study at $(A-D)$ Amargosa Flat Shallow (AFS) and (E-H) Amargosa Flat Deep (AFD) sites, Amargosa Desert, Nye County, Nevada, November 2011 

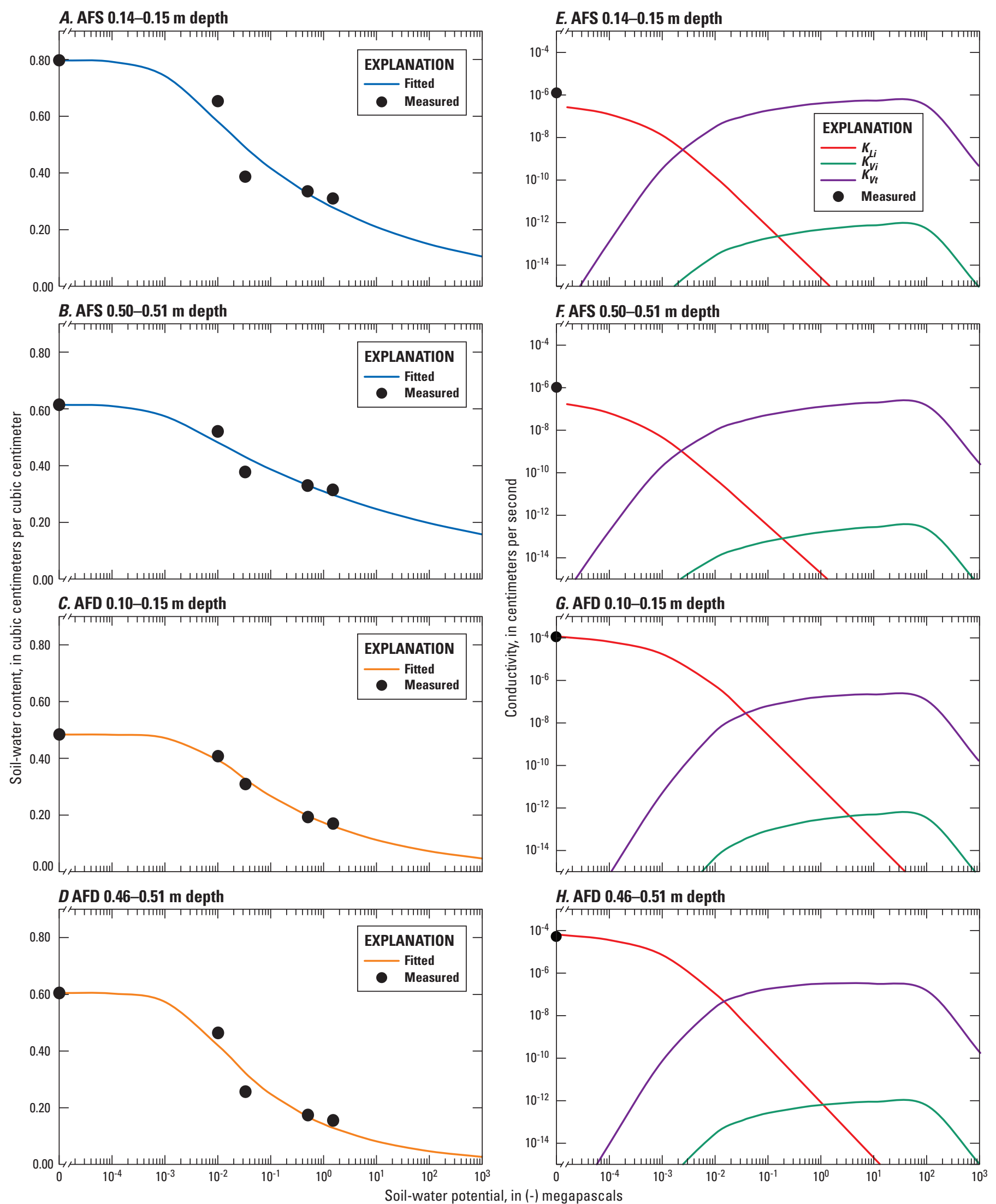

Figure 15. Volumetric soil-water retention data and calculated hydraulic-property functions for selected depths determined using cores collected at the beginning of the study at Amargosa Flat Shallow (AFS) site: $(A-B)$ soil-water retention, and (E-F) conductivity functions (isothermal liquid $\left[K_{L L}\right]$, isothermal vapor at 20 degrees Celsius $\left[K_{V j}\right]$, and thermal vapor $\left[K_{v l}\right]$ ); and Amargosa Flat Deep (AFD) site: $(\mathcal{C}-D)$ soil-water retention, and $(G-H)$ conductivity functions, Amargosa Desert, Nye County, Nevada, November 2011. 

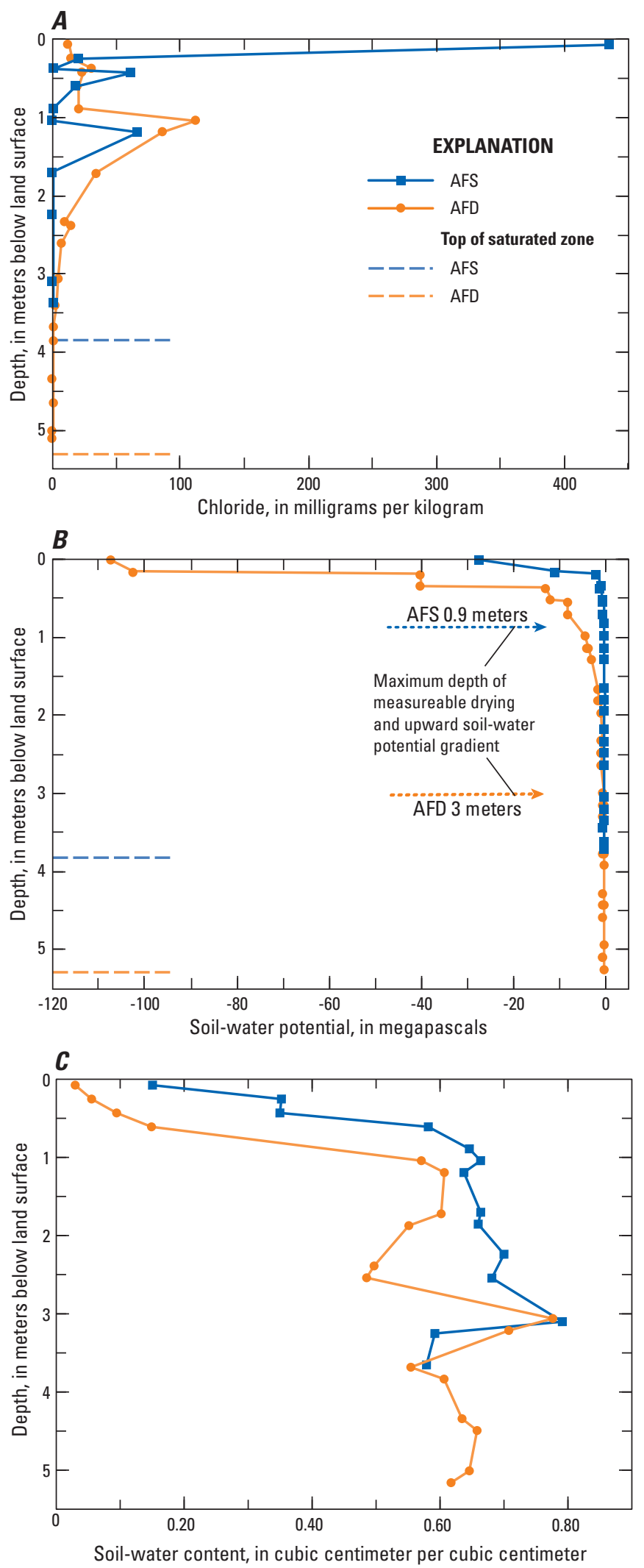

Figure 16. Soil profiles of $(A)$ chloride, $(B)$ water potential, and $(C)$ water content determined using cores collected the beginning of the study at Amargosa Flat Shallow (AFS) and Amargosa Flat Deep (AFD) sites, Amargosa Desert, Nye County, Nevada, November 2011. soil-water potentials indicates a strong upward driving force for water movement. These results along with the associated low soil-water content all reflect a high degree of seasonal or annual evapotranspirational drying and release of water from the upper $1 \mathrm{~m}$ bls of the soil profile to the atmosphere. The absence of downward advective-liquid transport below the dynamic near-surface moisture-fluctuation zone and associate chloride-concentration peak also is supported by the measurable soil drying and upward driving force for water movement which extend to a depth of at least $3 \mathrm{~m}$ (fig. 16B). Below $3 \mathrm{~m}$, AFD soil-water potentials averaged -0.3 $\pm 0.04 \mathrm{MPa}$ and depth-to-depth differences often fell within the uncertainty of the laboratory measurements, disallowing accurate determination of directional gradients. The field soil-water contents below $3 \mathrm{~m}$ averaged $0.65 \pm 0.07 \mathrm{~cm}^{3} / \mathrm{cm}^{3}$ (fig. 16C). Previous work at the ADRS has also documented upward directed soil-water potential gradients, but in this case the upward driving force for water movement extended down to a depth of at least $60 \mathrm{~m}$ (Walvoord and others, 2004) and the soil-water contents ranged from $0.04 \mathrm{~cm}^{3} / \mathrm{cm}^{3}$ just below the dynamic near-surface moisture-fluctuation zone to $0.14 \mathrm{~cm}^{3} / \mathrm{cm}^{3}$ just above the water table (Andraski, 1997; Mayers and others, 2005). The ADRS upward gradients are attributed to a deep drying front that is continuing to propagate downward in response to the paleohydrologic transition to present-day desert climate and xeric vegetation.

In strong contrast to the AFD site xeric-vegetation classic single-bulge shaped chloride profile, the AFS site sparse-saltgrass soil profile shows three separate and distinct zones of chloride accumulation (fig. 16A). The first bulge peak concentration was measured in the upper $0.15 \mathrm{~m}$ bls (435 mg/kg), the second bulge peaks at $0.4 \mathrm{~m}(62 \mathrm{mg} / \mathrm{kg})$, and the third bulge peaks at just below $1 \mathrm{~m}(67 \mathrm{mg} / \mathrm{kg})$ and its accumulation zone extends to a depth of about $1.6 \mathrm{~m}$ or less. Beneath each bulge, concentrations decrease to values that are uniformly low $(0.80 \pm 0.16 \mathrm{mg} / \mathrm{kg})$ and similar to those beneath the single AFD chloride bulge $(0.88 \pm 0.25 \mathrm{mg} / \mathrm{kg})$.

Combining the chloride data with other soil profile data again provides insight into past and ongoing water flow processes. For example, relative to AFD, one of the factors contributing to the high AFS near-surface accumulation of chloride is the lower saturated-hydraulic conductivity (fig. 13), which impedes downward liquid transport out of the $0-0.15 \mathrm{~m}$ soil zone under typical intermittent rainfall conditions. The AFS field data also show less substantial and shallower drying with the lowest soil-water potentials (-27.2 to -1.8 MPa), steepest upward soil-water potential gradients, and lowest soil-water content being measured in the upper $0.2-\mathrm{m}$ of the soil profile (figs. 15B and 15C). These nearsurface moisture conditions are reflective of the evaporationsalt precipitation processes that contribute to the retention and accumulation of chloride under typical environmental conditions, and along with the excretion of salt from saltgrass leaves, result in the visible salt deposit on the soil surface (fig. 5B). Salt deposits on the soil surface and within the soil pores, in turn, contribute to decreased subsurface 
drying at AFS because they impede the loss of soil-water vapor to the atmosphere (Nachshon and others, 2011; and references therein).

In contrast to the AFS near-surface chloride peak, the processes contributing to the two deeper chloride peaks (fig. 16A) are less clear, but it is hypothesized that these peaks represent two separate (and atypical) local-scale flooding and ponded-infiltration events that were sufficient to initiate deeper percolation and downward displacement of previously accumulated near-surface chloride. This hypothesis is generally supported by the topographic setting of the AFS site and its susceptibility to surface water run-on from the surrounding area. The posited flooding scenario also requires that dissolved constituents enter the land surface through the infiltration of both direct atmospheric deposition and salt-laden run-on. A comparison of the cumulative chloride inventories measured between land surface and the base of the deepest accumulation zone at each site shows that the AFS value $\left(11,538 \mathrm{mg} / \mathrm{cm}^{2}\right.$; 0 - to $1.6-\mathrm{m}$ depth) is greater than that for AFD $\left(9,870 \mathrm{mg} / \mathrm{cm}^{2}\right.$; 0 - to $3.6-\mathrm{m}$ depth), providing further support for the plausibility of the flooding hypothesis. The abrupt increase in chloride for the two deep AFS peaks also indicates almost piston-like displacement (fig. 16A), suggesting that the peak chloride concentrations approximate the once-active leading edges of percolation in the profile. Active percolation near the AFS 0.4-m chloride peak is not indicated because the measurable soil drying and upward driving force for water movement extend to a depth of at least $0.9 \mathrm{~m}$ (fig. 16B). Below $0.9 \mathrm{~m}$, there was no strong evidence of a wetting front as soil-water potentials averaged $-0.21 \pm 0.06 \mathrm{MPa}$ and the depth-to-depth differences for determining gradients typically were within the uncertainty of the laboratory measurements. The AFS field soil-water contents from 0.9 to $3.1 \mathrm{~m}$ bls were relatively uniform $\left(0.69 \pm 0.05 \mathrm{~cm}^{3} / \mathrm{cm}^{3}\right.$; fig. 16C). However, in the underlying hard-soil layer (about 3.1-3.8 m deep), the field value for the deepest soil-water content sample $(3.65 \mathrm{~m}$, $0.58 \mathrm{~cm}^{3} / \mathrm{cm}^{3}$; fig. $15 \mathrm{C}$ ) was similar to the laboratory-saturated value for a contiguous core sample $\left(3.56 \mathrm{~m}, 0.56 \mathrm{~cm}^{3} / \mathrm{cm}^{3}\right.$; Moreo and others, 2017), indicating the possible presence of a tension-saturated zone (Fetter, 1980) near the bottom of the AFS profile.

\section{Soil-Water and Temperature Variations}

Periodic soil-water content measurements at AFS, AFD, and ADRS were used to evaluate relative differences in the overall amount and seasonal changes in the amount of water held in the three soil profiles during the 2-year study. The increase in water held by the Amargosa Flat (fine-textured) compared with ADRS (coarse-textured) profiles, with maximum AFS and AFD soil-water contents exceeding those for ADRS by a factor of 6 or more are clearly indicated in figures $17 A-17 C$. The upper $2 \mathrm{~m}$ of each profile (figs. 17D-17F) highlight differences in the degree and depth to which soil-water content changes were measured in response to the infiltration, percolation, and redistribution of precipitation, and its subsequent return to the atmosphere by evapotranspiration. Temporal variations in AFS soil-water contents for each of the 0.15- to 2-m measurement depths were minimal (standard deviations $\leq 0.02 \mathrm{~cm}^{3} / \mathrm{cm}^{3}$ ) (fig. 17D). These results complement information about long-term flow processes discussed in section, "Soil Properties and LongTerm Processes Affecting Water Flow" and show that under current intermittent-precipitation and non-flooding conditions, no measurable percolation occurred below the 0.15-m depth. The AFD results also support that information, with dynamic near-surface processes being reflected by large temporal variations as much as $0.14 \mathrm{~cm}^{3} / \mathrm{cm}^{3}$ in the upper $1 \mathrm{~m}$ of the soil profile and little change in soil-water content at greater depths (standard deviations $\leq 0.02 \mathrm{~cm}^{3} / \mathrm{cm}^{3}$; fig. 17E). For the ADRS, where the creosote-bush rooting depth corresponds to the maximum-annual percolation depth of precipitation (about 0.75 to $1 \mathrm{~m}$ deep; Andraski, 1997), the periodic measurements made during this 2-year study were insufficient to capture either the short-duration or the seasonal root-zone wetting and drying that occurs in response to precipitation and ET (standard deviations $<0.01 \mathrm{~cm}^{3} / \mathrm{cm}^{3}$ ) (fig. 17F). In addition to a simple timing-of-measurement issue, the lack of observed soil-water content increases for the ADRS during this study is related to its coarser-textured soil and larger pores which, under wet conditions immediately following precipitation, will readily release infiltrated water for plant uptake and evapotranspiration. Previous long-term and precipitationevent based monitoring, however, have shown that temporal variations in root-zone soil-water content range between 0.02 and $0.14 \mathrm{~cm}^{3} / \mathrm{cm}^{3}$ (Fischer, 1992; Andraski, 1997; Johnson and others, 2007; Arthur and others, 2012).

Daily mean soil-water potential and soil temperature data collected at the Amargosa Flat sites are shown along with precipitation in figure 18. These data were used to evaluate site-to-site differences in the direction, magnitude, and temporal variation of driving forces that move water in the unsaturated zone. Site-to-site comparisons of the soilwater potential data were not always possible because of out-of-range measurements, instrument failure, or differences in measurement depths between sites. Within the limits of the available data, however, the field monitoring results identified major differences between the AFS and AFD subsurface environments. 

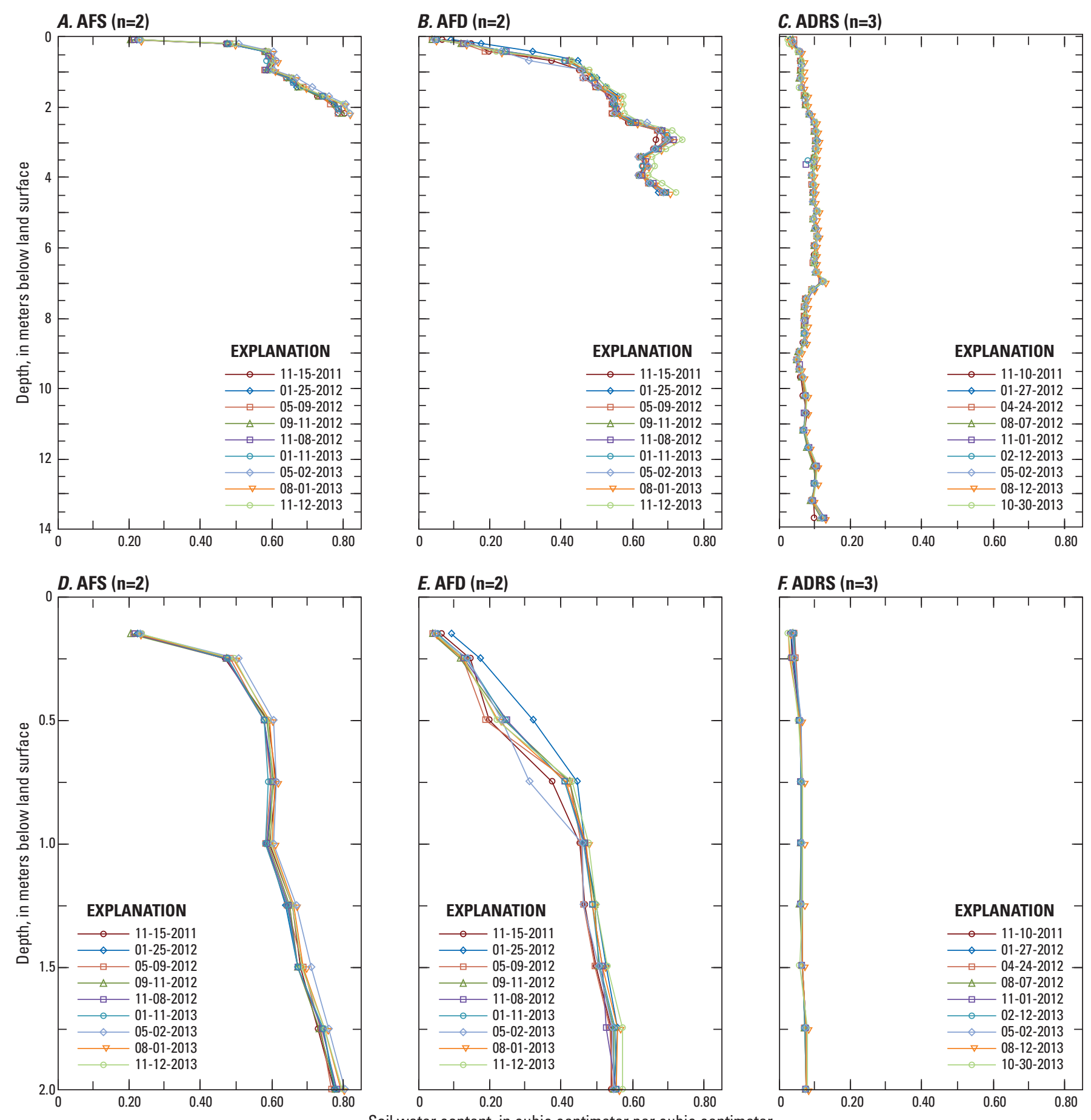

\section{E. AFD ( $\mathrm{n}=2)$}

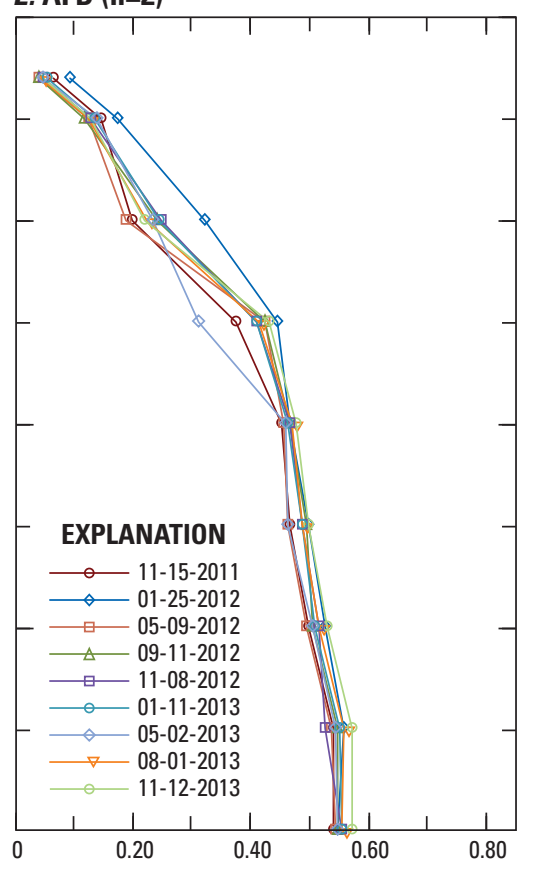

F. ADRS ( $\mathrm{n}=3)$

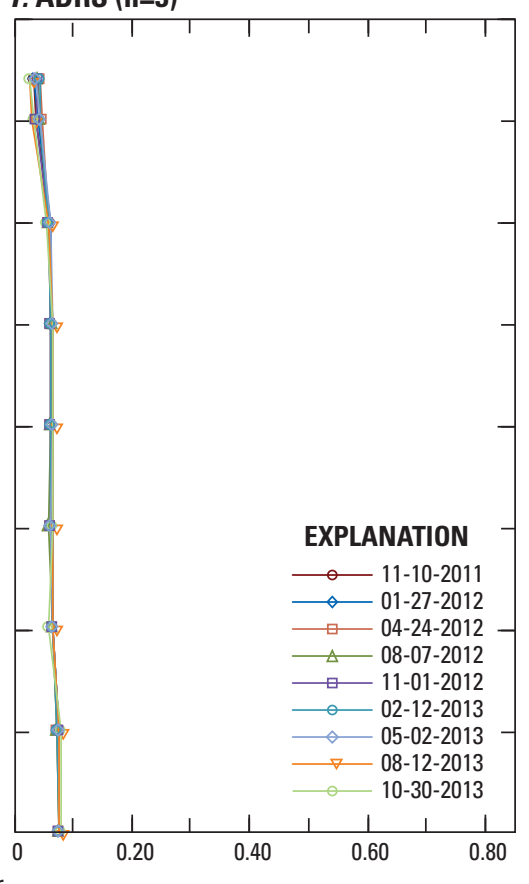

Figure 17. Periodic mean soil-water content measurements with depth at each site for the full profile and upper 2 meters, respectively: at $(A$ and $D$ ) Amargosa Flat Shallow (AFS) site, ( $B$ and $E$ ) Amargosa Flat Deep (AFD) site, and ( $C$ and $F$ ) Amargosa Desert Research Site (ADRS), Amargosa Desert, Nye County, Nevada, November 10, 2011, to November 12, 2013. The " $n$ " represents the number of replicate access tubes measured at each site. 
For AFS, the continuous soil-water potential record showed no evidence of precipitation penetrating to the 0.25-m depth during the 2-year study, even in response to the large (39 mm) storm that occurred on August 3, 2012 (fig. 18A). Instead the soil-water potential gradients between 0.25 and $1.07 \mathrm{~m}$ showed a persistent upward driving force for isothermal water flow. These results are consistent with the periodic soil-water content data, which indicated no percolation below the 0.15-m depth (fig. 17D) and the detailed AFS soil-water potential profile data, which indicated that drying and an upward gradient extended to a depth of at least 0.9 m (fig. 16B).

For AFD, rapid penetration of precipitation in the dynamic near-surface soil zone is reflected by the large increases in soil-water potential (0.25- and 0.50-m depths) that occurred in response to the August 2012 storm (fig. 18B).
The typically low values and rapid decreases in AFD soilwater potentials also illustrate the efficiency of water uptake by shadscale. For example, at the 0.25 -m depth, soil-water potentials were less than -10 MPa during extended periods of the study. This level of plant-induced soil drying is supported by Crofts and Van Epps (1975) who reported that shadscale can remain photosynthetically active at moisture-stress levels down to -11.5 MPa. A comparison of the AFD and AFS 0.50 -m depth soil-water potential data shows that the average value for AFD (-2.5 MPa) was about 10 times lower (more negative) than that for AFS (-0.2 MPa). Although the AFD 2.44-m time-series data are incomplete (fig. 18B), the average value $(-0.6 \mathrm{MPa})$ is similar to that for the AFD 2.46-m core measurement (-0.8 MPa; fig. 16B), which provides additional support for the previous conclusion that soil drying and an upward gradient for water movement extended to a depth of
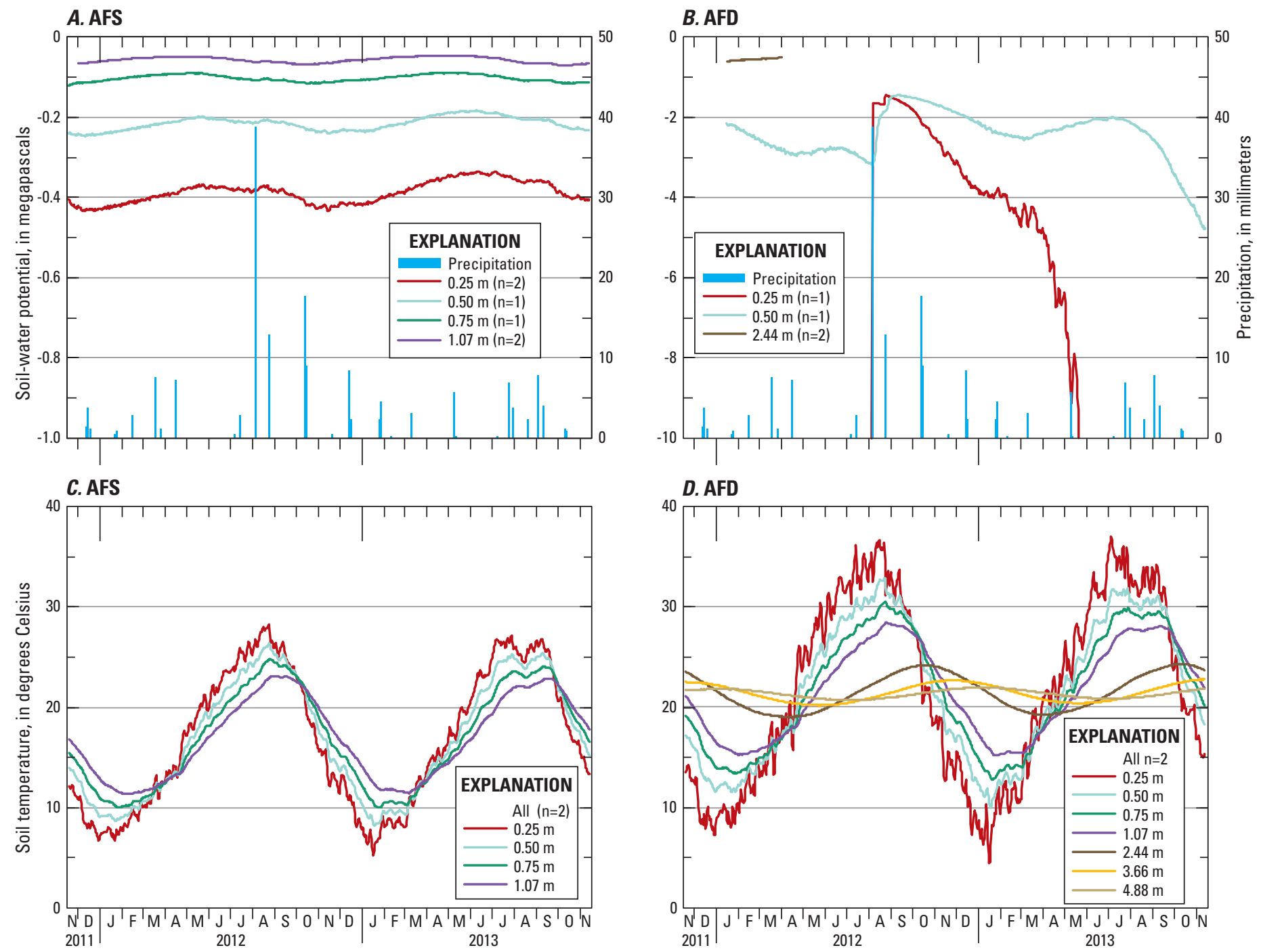

Figure 18. Daily mean soil-water potential for $(A)$ Amargosa Flat Shallow (AFS) and (B) Amargosa Flat Deep (AFD; values less than -10 megapascals are not shown) and soil temperature measurements for selected depths at (C) AFS and (D) AFD sites, Amargosa Desert, Nye County, Nevada, November 17, 2011, to November 12, 2013. The " $n$ " represents the number of sensors measured at each depth. 
at least $3 \mathrm{~m}$ bls (fig. 16B). Like AFD, previous ADRS timeseries measurements beneath xeric-shrub vegetation also documented (1) rapid penetration of precipitation into and subsequent drying of near-surface soil to levels equivalent to minimum active-plant values (-7.8 MPa for creosote bush; Odening and others, 1974) and (2) deep soil drying below the dynamic near-surface soil zone (Andraski, 1997).

The AFS and AFD soil temperature data show seasonal fluctuations and the propagation of annual temperature waves where, at each succeeding depth, the peak-to-trough amplitude becomes smaller and the maximum-and-minimum values lag progressively with time (figs. 18C and 18D).

For the four uppermost depths with complementary site data, the overall average temperature was cooler for AFS $\left(16.9^{\circ} \mathrm{C}\right)$ than for AFD $\left(21.7^{\circ} \mathrm{C}\right)$ and the seasonal fluctuations also were less for AFS than for AFD. For example, AFS daily mean 0.25 -m depth values ranged from 5.3 to $28.2^{\circ} \mathrm{C}$ and those for AFD ranged from 4.4 to $37.0^{\circ} \mathrm{C}$. Soil-profile temperatures are influenced by several interrelated processes, but one visible feature that contributed to smaller annual temperature fluctuations for the AFS site is the light-colored salt deposit on the soil surface (fig. 5A), which increases soil-surface reflectivity (albedo) and decreases the amount of available energy for heating of the soil. Like AFD, the darker ADRS soil surface (fig. $5 B$ and $5 C$ ) allows for greater heating and larger temperature fluctuations-ADRS 0.25 -m depth temperatures range between 5 and $36{ }^{\circ} \mathrm{C}$ (Andraski, 1997).

\section{Soil-Water Fluxes}

A single-phase independent process approach was used to estimate the relative magnitude of liquid-water and water-vapor fluxes at each site. Vertical fluxes of isothermal liquid, isothermal vapor, and thermal vapor were calculated using laboratory and field data. In section, "Soil Properties and Long-Term Processes Affecting Water Flow" laboratory hydraulic-property information is shown for samples from the upper parts of the AFS and AFD profiles (fig. 15).

The maximum downward isothermal-liquid flux that may have occurred in the upper $0.15 \mathrm{~m}$ of the Amargosa Flat soil profiles during the study can be estimated as being equal to the shallowest saturated-hydraulic conductivity value if a unit-gradient condition above the wetting front is assumed. For AFS, this maximum value is $1.1 \times 10^{-6} \mathrm{~cm} / \mathrm{s}$ $\left(9.5 \times 10^{-1} \mathrm{~mm} / \mathrm{d}\right)$ and for AFD this value is $2.3 \times 10^{-4} \mathrm{~cm} / \mathrm{s}$ $\left(1.9 \times 10^{2} \mathrm{~mm} / \mathrm{d}\right)$ (figs. $15 \mathrm{E}$ and $\left.15 \mathrm{G}\right)$.

For greater depths, vertical fluxes of isothermal liquid, isothermal vapor, and thermal vapor for the Amargosa Flat sites were estimated for depth intervals and periods with continuous soil-water potential monitoring data. For AFS, soil-water potential gradients resulted in isothermal-liquid fluxes that were consistently upward (positive values) for both depth intervals and flux magnitudes ranged from about $10^{-7}$ to $10^{-6} \mathrm{~mm} / \mathrm{d}$ (fig. 19A). The AFS isothermalvapor fluxes also were consistently upward for both depth intervals and ranged from $10^{-6}$ to $10^{-5} \mathrm{~mm} / \mathrm{d}$ (fig. 19B).
In contrast to the persistently upward isothermal-liquid and vapor fluxes, the AFS thermal-vapor flux direction varied with time in response to seasonally varying land surface temperatures and resultant soil-temperature gradients, which cause water vapor to move from warm-to-cool soilmaximum-upward fluxes occurred during the winter and maximum-downward fluxes occurred during the summer (fig. 19C). For both of the depth intervals, however, the average thermal-vapor flux was downward (about $-10^{-3} \mathrm{~mm} / \mathrm{d}$ ) because the temperature-dependent vapor diffusion coefficients are larger, on average, during periods of downward diffusion (when soil temperatures are higher) than during upward diffusion (when soil temperatures are lower) (Milly, 1996).

For the AFD site, the period of record for water-flux estimates was limited by dry conditions that resulted in out-of-range soil-water potential measurements and other instrumentation problems. For the 0.25- to 0.50-m interval, the downward isothermal-liquid fluxes during 2012 corresponded with increased soil-water potentials that were driven by two August storms and reflected the infiltration and percolation of precipitation in the soil profile (figs. 18B and 19D). Following the second storm, ET decreased shallow soil moisture sufficiently to change the isothermal-liquid flux from downward to persistently upward (about $10^{-5} \mathrm{~mm} / \mathrm{d}$ ). The August 2012 storms also led to a brief period of downward isothermal-vapor fluxes for the 0.25 - to 0.50 -m interval (fig. 19E), but subsequent drying of shallow soil during 2012 and 2013 led to upward fluxes on the order of $10^{-3} \mathrm{~mm} / \mathrm{d}$. The AFD thermal-vapor fluxes for the 0.25 - to $0.50-\mathrm{m}$ interval showed a seasonal fluctuation that followed changes in the soil-temperature gradient, with upward-maxima in the winter and downward-maxima in the summer (fig. 19F). For the available period of record (289 d), the average thermal-vapor flux was downward (about $-10^{-4} \mathrm{~mm} / \mathrm{d}$ ) but this value is biased low because it did not include estimates during two summer months (June and July).

The Amargosa Flat soil-water flux results show how the individual flux components are influenced by dynamic soil-plant-atmosphere interactions. For example, liquidwater and water-vapor movement can occur simultaneously and in opposite directions, as shown in figure 19. The single-phase independent-process flux calculations used herein do not account for the interactions and feedbacks that affect the strongly coupled processes of liquid, vapor, and heat flow. Thus, definitive comparisons of water transport mechanisms and total water fluxes at the field sites are not possible, but some qualitative observations can be made. First, for the duration of the study, the AFS isothermalliquid and isothermal-vapor fluxes below its dynamic nearsurface $(0-0.15 \mathrm{~m})$ moisture fluctuation zone were small, but consistently upward. This suggests the presence of a subsurface soil-moisture source that contributes a slow but relatively persistent upward release of water in response to evapotranspirational demands established in the overlying 

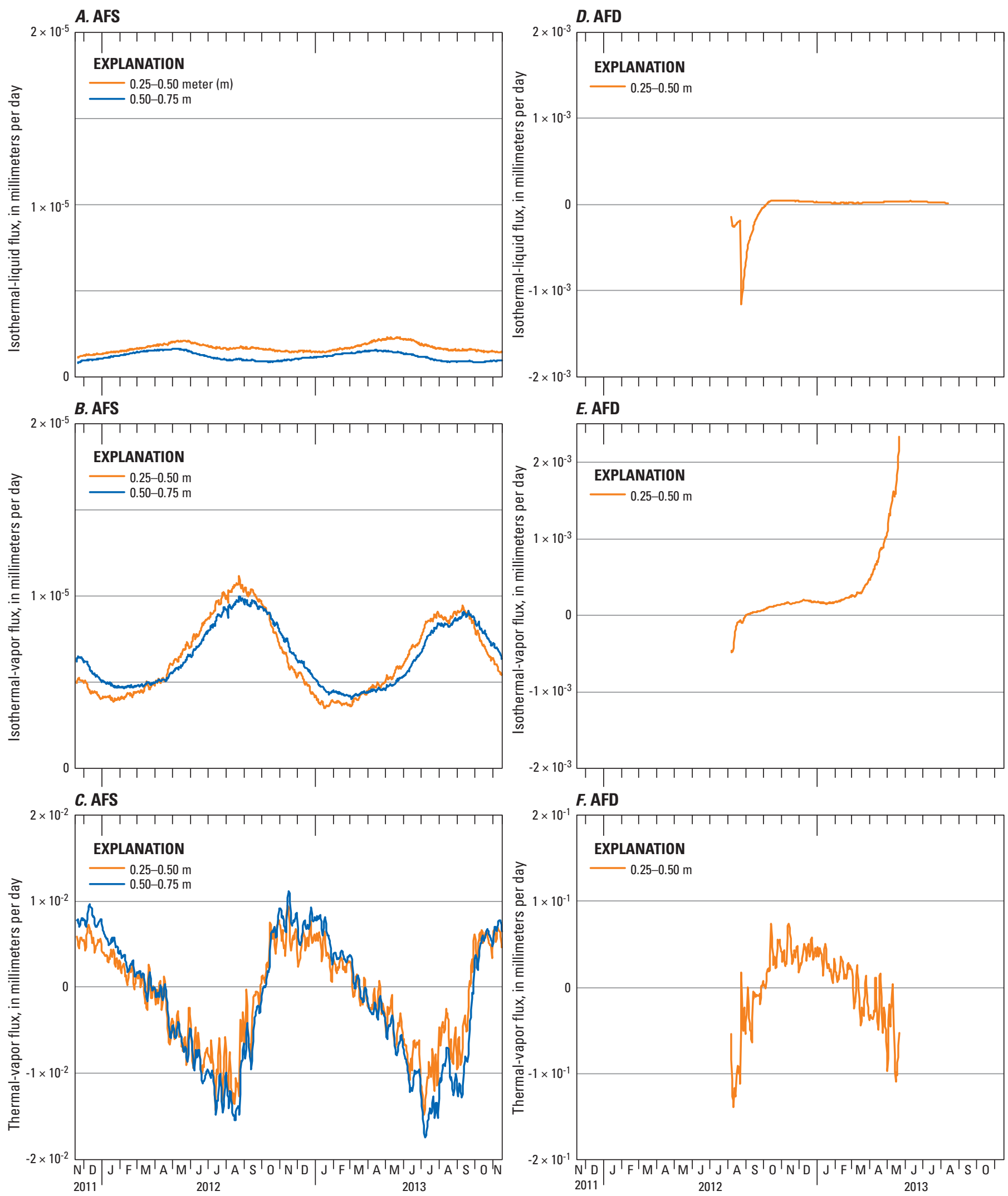

Figure 19. Daily total vertical-flux estimates for isothermal liquid, isothermal vapor, and thermal vapor at $(A-C)$ Amargosa Flat Shallow (AFS) site and (D-F) Amargosa Flat Deep (AFD) site, Amargosa Desert, Nye County, Nevada, November 18, 2011, to November 8, 2013. Sign convention is that upward fluxes are positive. Fluxes were estimated for depth intervals with volumetric hydraulic-property data (fig. 15) and periods with continuous soil-water potential data (fig. 18). 
near-surface soil. Second, the AFD results show how dynamic processes in its dynamic near-surface $(0-1 \mathrm{~m})$ moisture fluctuation zone can have large, but sometimes shortlived effects on water fluxes. For example, episodic storm events led to brief periods of downward isothermal-liquid and isothermal-vapor fluxes in the AFD near-surface soil zone, but efficient soil drying by xeric vegetation resulted in a rapid reversal and return to typically upward-directed isothermal fluxes. Third, the results from both AFS and AFD suggest that the overall magnitude of water-flux components may be greatest for thermal-vapor flux. This observation is consistent with previous ADRS work that estimated thermalvapor fluxes to often be two to four orders of magnitude greater than isothermal-liquid and isothermal-vapor fluxes (Andraski, 1997). Finally, the subsurface water fluxes shown in figure 19 must be viewed in relation to the potential sources of uncertainty associated with the estimated values. Soil water-flux equations 8,9 , and 10 each include a conductivity term and a gradient term - of the two, the conductivity term is considered to be more uncertain because the gradient term is based on field measurements. For the isothermal-liquid flux calculations, the unsaturated hydraulic-conductivity function was estimated from a measured saturated hydraulic conductivity, a fitted soil-water retention curve, and a predictive capillary-flow model. Comparisons of calculated and measured unsaturated hydraulic-conductivity values show differences can be in excess of 2 orders of magnitude (Khaleel and others, 1995). The isothermal- and thermal-vapor conductivity terms also rely on estimated hydraulic-property information such as air-filled porosity, which is calculated from the fitted soil-water retention curve. For the AFS and AFD soil-water retention curves, the difference between fitted and laboratory-measured water contents averaged $0.077 \pm 0.080 \mathrm{~cm}^{3} / \mathrm{cm}^{3}$. For the thermal-vapor conductivity term, another source of uncertainty is the enhancement factor, which was calculated as a function of clay content and fitted soil-water content, and can range from a value of 1 (at low water contents) and to greater than 10 (at high water contents) (Campbell, 1985). Despite the widespread use of such factors in calculations of thermal-vapor flow, the existence of porescale enhancement mechanisms is the subject of ongoing debate and study (for example, Shokri and others, 2009; Shahraeeni and Or, 2012).

The Amargosa Flat unsaturated-zone flow component of the study did not directly investigate water sources contributing to ET, but the results do indicate that in addition to ET derived from present-day precipitation and infiltration into the dynamic near-surface moisture fluctuation zone, there is a subsurface water source that is also contributing to ET. One potential interpretation of the data is that (1) groundwater is moving into the unsaturated zone as a result of capillary rise and (2) this capillary-rise input is supporting the subsequent, sustained release and upward transport of groundwater in response to the atmospheric evapotranspirational demand. As a simple plausibility test of this capillary-rise scenario, relative comparisons were made between field-estimated Amargosa
Flat capillary-fringe heights and text-book capillary-fringe heights. First, referring to figure 16B, if the depth difference between the top of the saturated zone and the bottom of the present-day drying front is assumed to represent the capillary-fringe height, then the field-estimated height for AFS of $3.8-0.9=2.9 \mathrm{~m}$ and height for AFD of $5.3-3.0=$ $2.3 \mathrm{~m}$. Second, the Amargosa Flat soils are dominated by silt and clay (fig. 12) and text-book capillary-fringe heights for such materials are on the order of 1.5 and $3.0 \mathrm{~m}$, respectively (Fetter, 1980). These text-book values are only approximate and can be affected by horizontal and vertical textural variations in the soil profile, but their correspondence with the field-estimated values strongly support a sustained capillary supply and release effect on the AFS and AFD unsaturatedflow systems. Because the ability of a soil to transmit water decreases rapidly with increasing soil dryness and increasing depth to the water source, the capillary effect on upward transport would be most substantial for AFS because it could bring the top of the capillary-rise water source to within $0.9 \mathrm{~m}$ of land surface. At the other extreme is the ADRS control site, where the ability of the soil to transmit water toward land surface is not only limited by the coarse texture and dryness of the profile, but also by the great depth of the unsaturated zone $(110 \mathrm{~m})$.

\section{Stable Isotope Water Sourcing}

Stable isotopic compositions of oxygen $\left(\delta^{18} \mathrm{O}\right)$ and hydrogen $\left(\delta^{2} \mathrm{H}\right)$ were used as conservative water-mass tracers to investigate water movement in the atmosphereplant-soil-groundwater continuum and to evaluate water sources and soil depths that contributed to total ET. The November 2011 Amargosa Flat $\delta^{18} \mathrm{O}$ and $\delta^{2} \mathrm{H}$ results for cumulative precipitation (July-November 2011), soil-core water profiles, and groundwater are shown in figure 20. In strong contrast to the wide range of isotopic compositions observed for the AFS, AFI, and AFD unsaturated-zone soil-core water profiles, the precipitation and groundwater signatures showed little variation among sites. Precipitation averaged $(n=2)-4.6 \pm 0.2$ per mil for $\delta^{18} O$ and $-39 \pm 0.3$ per mil for $\delta^{2} \mathrm{H}$. Saturated-zone soil-core and well samples of groundwater averaged $(\mathrm{n}=8)-14.0 \pm 0.3$ per mil for $\delta^{18} \mathrm{O}$ and $-107 \pm 1.7$ per mil for $\delta^{2} \mathrm{H}$.

The more positive the $\delta^{18} \mathrm{O}$ and $\delta^{2} \mathrm{H}$ values the greater the evaporative enrichment whereby heavier isotopes $\left({ }^{18} \mathrm{O}\right.$ and $\left.{ }^{2} \mathrm{H}\right)$ are preferentially retained and lighter isotopes $\left({ }^{16} \mathrm{O}\right.$ and $\left.{ }^{1} \mathrm{H}\right)$ are lost as water transitions from the liquid to vapor phase (fig. 20). The Amargosa Flat soil-water isotope profiles exhibit features characteristic of water loss by evaporation through unsaturated soils, with values decreasing from most-enriched near land surface to relatively constant at depth. The AFI and AFD profiles show a classic, near-exponential decrease in isotopic composition with depth (Barnes and Allison, 1988; Walvoord and others, 2004), but the scale of sampling was not fine enough to capture this trend for the AFS site. The exact 

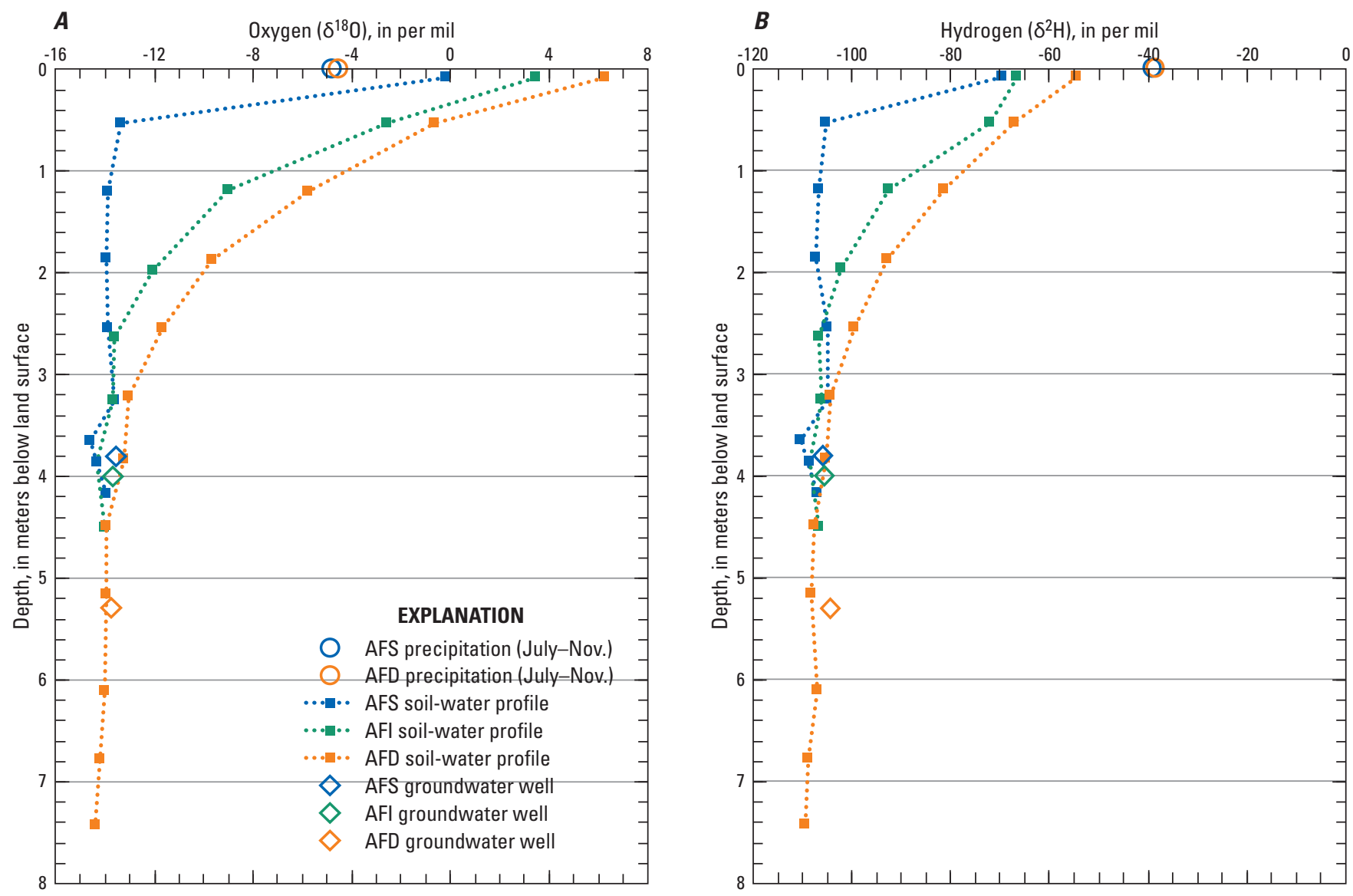

Figure 20. Stable-isotope compositions of $(A)$ oxygen $\left(\delta^{18} 0\right)$ and $(B)$ hydrogen $\left(\delta^{2} H\right)$ for cumulative precipitation, soil water with depth below land surface, and groundwater sampled at the beginning of the study at Amargosa Flat Shallow (AFS), Amargosa Flat Intermediate (AFI), and Amargosa Flat Deep (AFD) sites, Amargosa Desert, Nye County, Nevada, November 2011.

base of the AFS, AFI, and AFD evaporative-enrichment zones was not identified by the data, but these depths are estimated to be about $0.9 \mathrm{~m}$ for AFS, $2.3 \mathrm{~m}$ for AFI, and $2.9 \mathrm{~m}$ for AFD (fig. 20A and 20B). Below these depths, the isotopic composition of unsaturated-zone soil-profile water is similar to groundwater, indicating that the input of groundwater into the unsaturated zone is driven by capillary rise from the saturated zone, and the capillary fringe is serving as a water source for the sustained supply and replenishment of groundwater that is being released through the overlying unsaturated zone in response to the atmospheric evaporative demand. For comparison with the Amargosa Flat results where the depth to water is only 3.8 to $5.3 \mathrm{~m}$ bls, previous ADRS work showed an evaporative-enrichment zone that extended to a depth of 40-60 m and the source water for this upward evaporative release was not groundwater, but paleo-percolation water that had been stored in the 110-m thick unsaturated zone for thousands of years (Walvoord and others, 2004).

The Amargosa Flat stable-isotope profile results are consistent with the previous discussion of long-term processes affecting water movement below the dynamic near-surface moisture fluctuation zone. For example, the AFS and AFD stable-isotope profiles (fig. 20) support the (1) lack of deep percolation and (2) maximum depths of soil drying and upward isothermal-flow gradients that were documented by the chloride and soil-water potential measurements (AFS, $0.9 \mathrm{~m}$ and AFD, $3 \mathrm{~m}$; figs. 16A and 16B). The soilwater potential data also indicated that capillary-rise could be a mechanism by which groundwater moved up into the unsaturated zone, and this is confirmed by the stableisotope profiles that reflect an unevaporated groundwater signature occurring to within 0.9 and $2.9 \mathrm{~m}$ of land surface for AFS and AFD, respectively (fig. 20). In combination, the AFS and AFD unsaturated-flow and stable-isotope results indicate low, but quasi-steady state releases of groundwater through the unsaturated zone in response to the atmospheric evapotranspirational demand.

The AFI site was not instrumented or sampled for detailed study, but relative comparisons among the three Amargosa Flat stable-isotope profiles provide insight into important factors and processes affecting the subsurface flow 
regime at that site. For example, the AFI and AFD isotopic profiles show a strong similarity in shape, but the AFI profiles are shifted to the left (fig. 20). One primary factor likely contributing to the similar-shaped profiles is the common xeric-shrub community, which promotes rapid drying in the dynamic near-surface soil zone and a relatively persistent demand for soil water to be drawn up from greater depths. The shift in the AFI compared to AFD isotopic profiles indicates that the degree of unsaturated-zone drying was somewhat less for the AFI site. Factors that may contribute to this difference between AFI and AFD include lighter-colored soil surface at AFI, which decreases the available energy and atmospheric evaporative demand, shallower depth to groundwater at AFI, and potential site-to-site differences in soil-profile properties that govern both capillary rise into and transmission of water through the unsaturated zone.

Relations between Amargosa Flat and ADRS stableisotopic compositions with respect to published global and local meteoric water lines (GMWL and LMWL) and other data were used to further characterize source waters and evaluate temporal variations in source-water contributions to ET. For the Amargosa Flat study sites, this evaluation included $\delta^{18} \mathrm{O}-\delta^{2} \mathrm{H}$ diagrams for periodically sampled cumulative precipitation, groundwater, near-surface and deeper soil water, and plant water (figs. 21A, 21B, and 21C). For the ADRS control site, deeper soil water was not sampled and groundwater was sampled in April 2013 (fig. 21D).

The period-of-record for the isotopic sampling of cumulative precipitation at each of the four study sites was short, but the data showed good agreement with two LMWLs, which were established within $130 \mathrm{~km}$ of Amargosa Flat (fig. 21). The Winograd and others (1998) LMWL, was derived from samples collected above a 1,650-m elevation in the Spring Mountains in southern Nevada (fig. 1), whereas the Tyler and others (1996) LMWL was derived from samples collected at a 960-m elevation in south central Nevada. Studysite precipitation signatures varied among collection periods, with samples collected during cooler periods (NovemberMay) generally showing less evaporative enrichment (more negative $\delta^{18} \mathrm{O}$ and $\delta^{2} \mathrm{H}$ ) than samples collected during warmer periods (May-November). For example, the Amargosa Flat volume-weighted means for cooler periods were -11.2 per mil for $\delta^{18} \mathrm{O}$ and -86 per mil for $\delta^{2} \mathrm{H}$, whereas those for warmer periods were -7.6 per mil for $\delta^{18} \mathrm{O}$ and -58 per mil for $\delta^{2} \mathrm{H}$.

Evaluations of spatial and temporal variations in the isotopic compositions of Amargosa Flat groundwater and precipitation, and comparisons with other published data were used to further characterize groundwater in the Amargosa Flat study area. The groundwater signature was similar among all three sites and remained constant during the study (figs. 21A, 21B, and 21C). The average Amargosa Flat groundwater composition ( $\mathrm{n}=9$, three sites and three dates) $\left(\delta^{18} \mathrm{O}=-13.7 \pm 0.1\right.$ per mil; $\delta^{2} \mathrm{H}=-105 \pm 0.7$ per mil $)$ and the average ADRS April 2013 groundwater ( $\mathrm{n}=2$ wells) $\left(\delta^{18} \mathrm{O}=-13.8\right.$ per mil; $\delta^{2} \mathrm{H}=-106$ per mil; fig. $\left.21 D\right)$ were substantially more negative than the cool-season precipitation values measured during the 2-year study. This difference indicates that local-scale valley-floor recharge at the study sites is minimal under present climate conditions (Winograd and Thordarson, 1975), which concurs with the conclusion of negligible deep percolation that was drawn from the AFS, AFD, and ADRS chloride profile data. The average Amargosa Flat groundwater $\delta^{2} \mathrm{H}$ value, however, was similar to regional $\delta^{2} \mathrm{H}$ values reported for springs in Ash Meadows (-106 per mil, Winograd and Friedman, 1972; -103 per mil, Winograd and Pearson, 1976). This similarity indicates that groundwater in the Amargosa Flat study area likely is well connected with and representative of the regional groundwater-flow system. Regional groundwater in Ash Meadows was recharged during the last 10,000 years primarily by precipitation in the Spring Mountains in combination with a lesser contribution possibly by underflow from Pahranagat Valley located about $150 \mathrm{~km}$ to the northeast (Winograd and Friedman, 1972; Winograd and Thordarson, 1975; Thomas and others, 1996).

Comparisons between $\delta^{18} \mathrm{O}$ and $\delta^{2} \mathrm{H}$ soil-water and plantwater signatures were used to investigate the depth zone (or zones) from which the AFS and AFD plants extracted soil water during the course of the study. The specific objective was to determine if plant-water extraction was limited to the dynamic near-surface zone where soil moisture fluctuated in response to precipitation and ET, or did it also extend into deeper soil zones? For this evaluation, the dynamic nearsurface soil zones were approximated using the chloride profile and periodic soil-water content results (figs. 16A, 17D, and $17 E$ ) and were defined as: AFS, upper $0.15 \mathrm{~m}$; AFD, upper $1 \mathrm{~m}$.

The AFS soil-water $\delta^{18} \mathrm{O}-\delta^{2} \mathrm{H}$ signatures (fig. 21A) show two distinct populations - one corresponding with samples that encompassed the dynamic near-surface zone and the other with samples from the deeper soil zone. The effect of dynamic processes is also reflected by increased temporal variability among the periodic near-surface compared to deep soil-water data. A comparison of the soil and plant $\delta^{18} \mathrm{O}-\delta^{2} \mathrm{H}$ signatures shows that plant water for three of four sampling dates cluster near those for near-surface soil, but plant water for May 2012 is between the near-surface and deeper soil water. Within the limits of the periodic-sampling dataset and recalling that plant-water signatures represent an integrated measure of overall plant-water uptake, these results indicate that the AFS saltgrass primarily extracted water from the near-surface soil zone, but under certain conditions at least some of the saltgrass water was extracted from deeper soil. For example, the close agreement between the August 2012 plant- and soil-water signatures reflects the ample availability and uptake of near-surface soil moisture following high precipitation $(12.8 \mathrm{~mm})$ that fell 3 days prior to sample collection (figs. 18A and 21A). In contrast, the May 2012 plant-water $\delta^{18} \mathrm{O}-\delta^{2} \mathrm{H}$ signature plots between the near-surface and deeper soil-water values, indicating that the lack of precipitation during the 24-day period prior to sampling may have led to the uptake of at least some, if not all of its water from below the dynamic near-surface zone 


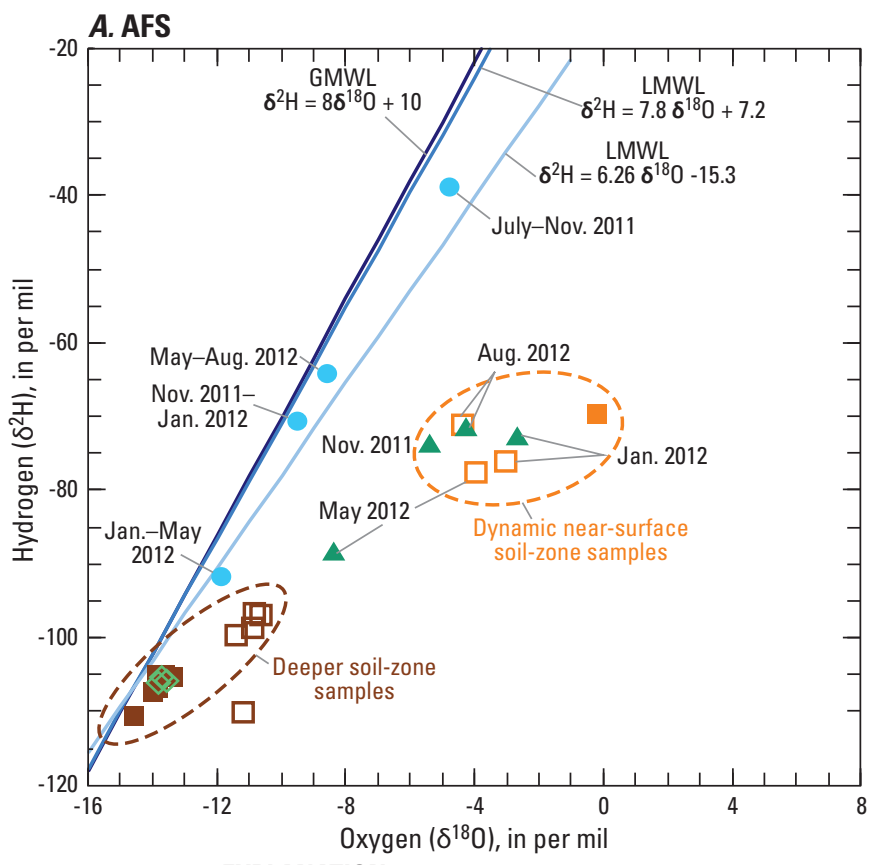

EXPLANATION

$\diamond$ Groundwater

Soil-water profile Nov. 2011 (0-0.15 m bls)

Mean soil water $(0.0-0.2 \mathrm{~m}$ bls, $\mathrm{n}=2)$

Soil-water profile Nov. 2011 (0.5-3.7 m bls

$\square$ Mean soil water $(0.4-0.6 \mathrm{~m}$ bls, $\mathrm{n}=2)$

Mean saltgrass water $(n=2)$

C. AFD

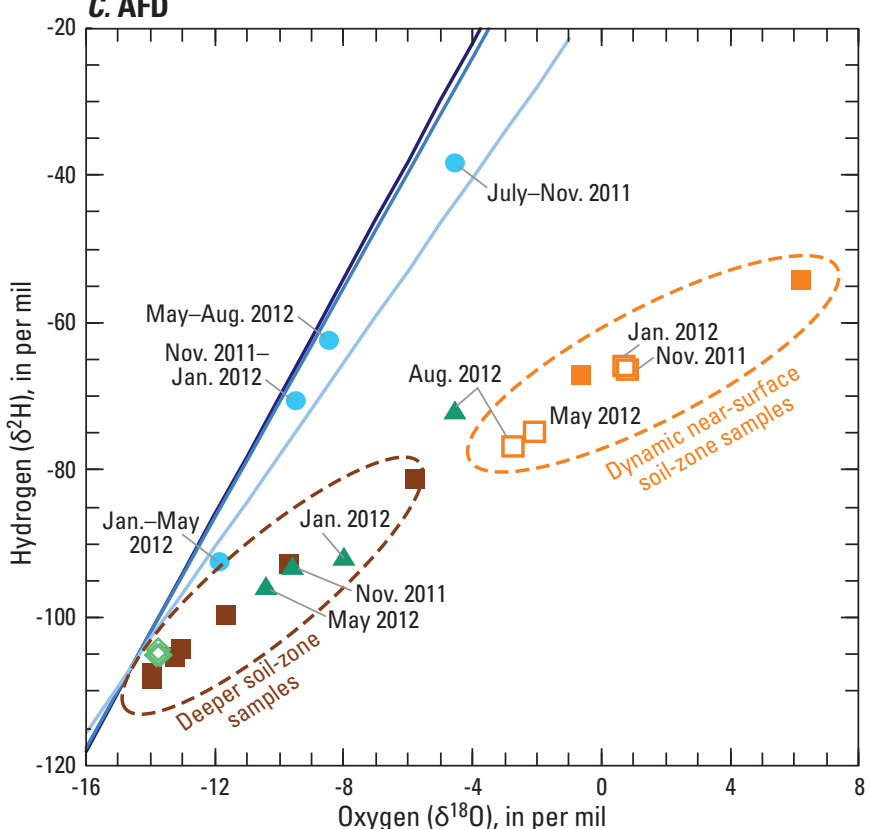

EXPLANATION

$\triangle$ Groundwater

Soil-water profile Nov. $2011(0.08-0.5 \mathrm{~m}$ bls $)$

Mean soil water $(0.4-0.6 \mathrm{~m} \mathrm{bls}, \mathrm{n}=2)$

Soil-water profile Nov. 2011 (1.2-5.2 m bls)

- Mean shadscale water $(\mathrm{n}=2)$

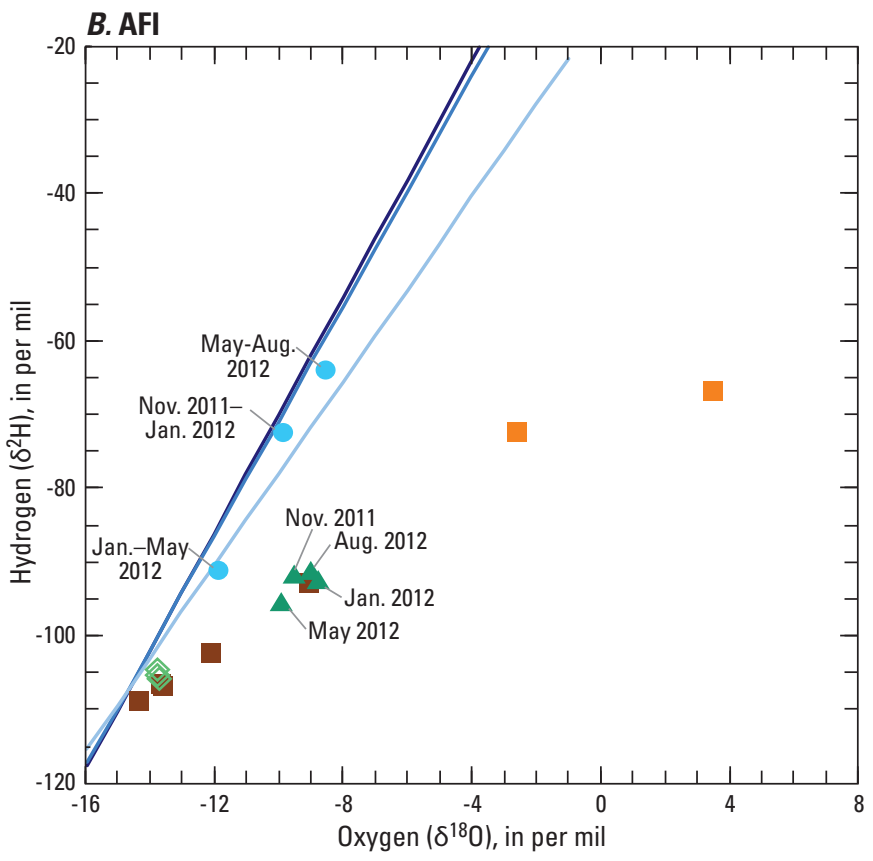

EXPLANATION (ALL)

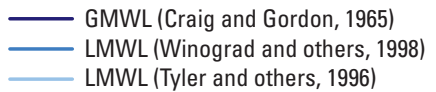

- LMWL (Tyler and others, 1996

EXPLANATION

$\checkmark$ Groundwater

Soil-water profile Nov. 2011 (0.08-0.5 m bls)

Soil-water profile Nov. 2011 (1.2-3.9 m bls)

Mean shadscale water $(n=2)$

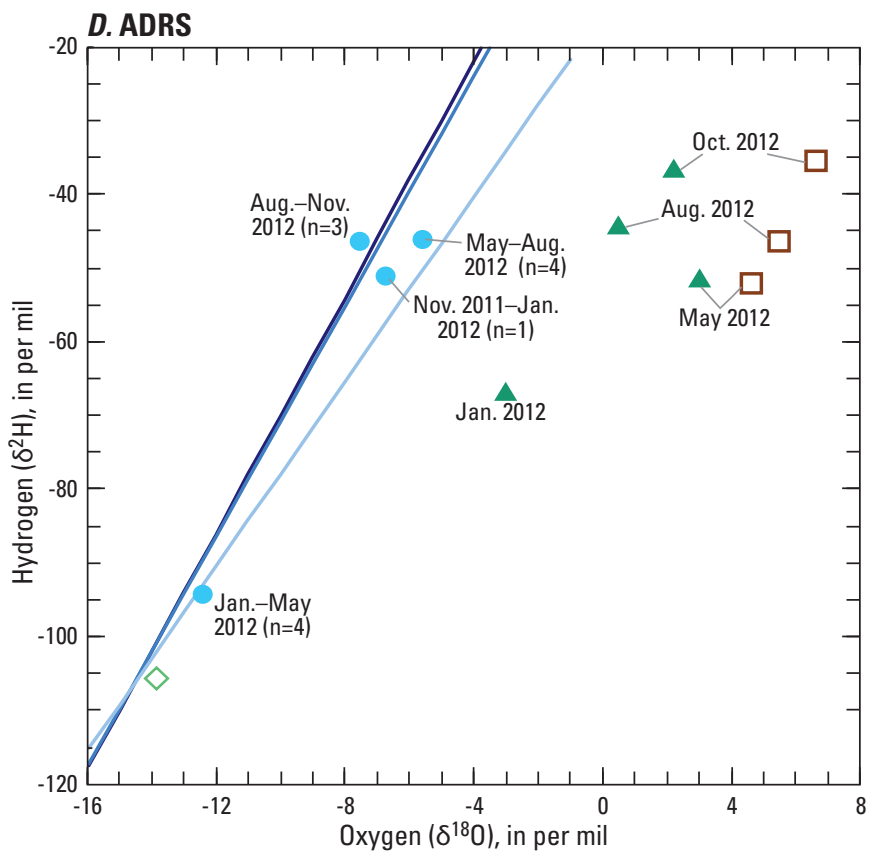

EXPLANATION (ALL)

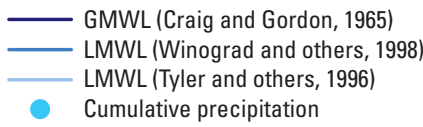

Note: $\mathrm{m}$ bls, meters below land surface

Figure 21. Relations between stable-isotope compositions of oxygen $\left(\delta^{18} 0\right)$ and hydrogen $\left(\delta^{2} \mathrm{H}\right)$ for published global and local meteoric water lines (GMWL and LMWL), and for compositions of cumulative precipitation, groundwater, soil water, and plant water at $(A)$ Amargosa Flat Shallow (AFS) site, (B) Amargosa Flat Intermediate (AFI) site, (C) Amargosa Flat Deep (AFD) site, and (D) Amargosa Desert Research Site (ADRS), July 2011-November 2012, and for ADRS groundwater, April 2013, Amargosa Desert, Nye County, Nevada. 
(fig. 21A). However, the large difference between the plantwater and unevaporated-groundwater signatures indicated that the AFS saltgrass did not rely on the direct uptake of groundwater from the capillary fringe even though it occurred within $0.9 \mathrm{~m}$ of land surface (figs. 20 and 21A). The exact reason for this is unknown, but it concurs with observations that the AFS saltgrass usually appeared stressed (fig. 5A) and root development primarily occurred in the upper $0.15 \mathrm{~m}$. These observations are worthy of note because saltgrass is considered a phreatophyte when it occurs within groundwater discharge areas (Robinson, 1958) and the word phreatophyte is generally defined as a plant that withdraws groundwater from the saturated zone or the overlying capillary fringe (Meinzer, 1927).

A source of uncertainty in the AFS (saltgrass) and AFD and AFI (shadscale) $\delta^{2} \mathrm{H}$ results is the potential effect of hydrogen-isotopic fractionation during water uptake by desert halophytes. A detailed evaluation was beyond the scope of this study, but the August 2012 AFS data provide the basis for a simple assessment. For example, if the $0-0.2-\mathrm{m}$ soil samples captured the complete depth zone from which root uptake was occurring at the time of sampling, then the small difference between $\delta^{2} \mathrm{H}$ for plant water (-71.3 per mil) and shallow-soil water (-71.2 per mil) implies negligible fractionation during water uptake. For comparison, studies that have documented fractionation by halophytic coastal-wetland species reported plant-water $\delta^{2} \mathrm{H}$ values that were about $2-10$ per mil less enriched (more negative) than those for the source water (Lin and Sternberg, 1993).

The AFD depth zone (or zones) from which plants extracted soil water was evaluated using the $\delta^{18} \mathrm{O}-\delta^{2} \mathrm{H}$ data shown in figure 21C. The AFD soil-water signatures also group into two populations, one corresponding with samples from within the dynamic near-surface soil zone and the other with samples from the deeper soil zone. Unlike AFS, however, the AFD dynamic soil-zone signatures show greater temporal variability and more extensive enrichment due to increased evapotranspirational drying (figs. $21 \mathrm{~A}$ and 21C) - these siteto-site differences directly complement those identified by the unsaturated-zone hydrologic data. In strong contrast to the AFS results, only one of the four AFD plant-water signatures (August 2012) was near the AFD range observed for the dynamic-surface soil, and the other three all plot within the range for deeper soil. The general correspondence between the August 2012 AFD plant and 0.4-0.6-m soil signatures is attributed to the high precipitation and subsequent percolation (fig. 18B) that provided a readily available water source for plant uptake. These August 2012 data, however, are not suited for an evaluation of potential hydrogen-isotopic fractionation during water uptake by the halophytic shadscale because the 0.4-0.6-m samples captured only part of the soil zone from which root uptake was likely occurring. The AFD plantwater signatures for the other three dates (November 2011,
January 2012, and May 2012) all cluster near the 1.9-m depth soil-profile value, indicating that under drier conditions the shadscale extracted a larger amount of its water from the deeper-soil zone- the source of which appears isotopically traceable back to unevaporated groundwater in the capillary fringe and saturated zone (figs. 20 and 21C). This finding is of interest because xeric shrubs are broadly classified as being reliant on incident precipitation and able to survive for long periods between precipitation events (Robinson, 1958). Results from this study indicate that another survival mechanism for the AFD shadscale includes its opportunistic use of groundwater that has been released from the capillary fringe and is moving upward through the unsaturated zone in response to the atmospheric evaporative demand.

The AFI site was not instrumented for detailed ET or unsaturated-zone monitoring, but insight into shadscale water uptake at this site can be gleaned from comparisons between the AFI and AFD $\delta^{18} \mathrm{O}-\delta^{2} \mathrm{H}$ data shown in figures $21 \mathrm{~B}$ and 21C. First, for the November 2011, January 2012, and May 2012 samples, the mean AFI shadscale signatures $\left(\delta^{18} \mathrm{O}=-9.3\right.$ and $\delta^{2} \mathrm{H}=-92.3$ per mil) were markedly similar to those for the AFD site $\left(\delta^{18} \mathrm{O}=-9.4\right.$ and $\delta^{2} \mathrm{H}=-93.4$ per mil). Second, the AFI plant values all cluster near the soil-profile $1.2-\mathrm{m}$ depth signature. These results indicate the AFI shadscale also obtained at least some of its water from a deeper, groundwatersupplied soil zone (figs. 20, 21B, and 21C). The exact reason similar AFI and AFD plant-water signatures correspond with different soil-profile sample depths (AFI about $1.2 \mathrm{~m}$ and AFD about 1.9 m; fig. 20) is not known, but the shallower AFI depth may reflect increased availability of upward-moving plant-extractable liquid-phase water. Factors that could contribute to this include the shallower depth to groundwater at AFI and the potential differences in soil-profile properties that could enhance capillary rise into and transmission of water through the AFI unsaturated zone.

The ADRS control-site $\delta^{18} \mathrm{O}-\delta^{2} \mathrm{H}$ soil- and plant-water data were not analyzed in detail, but are included for general comparisons with the Amargosa Flat data (fig. 21). For example, the consistently high ADRS soil-water signatures for the $0.2-0.4-\mathrm{m}$ depth samples $\left(\delta^{18} \mathrm{O}, 4.7\right.$ to 6.7 per mil; $\delta^{2} \mathrm{H}$, -52 to -35 per mil) reflect the negligible contribution from groundwater $\left(\delta^{18} \mathrm{O},-13.8\right.$ per mil; $\delta^{2} \mathrm{H},-106$ per mil) and the high degree of soil drying and evaporative enrichment at the control site. In contrast, only one Amargosa Flat sample showed a comparable level of enrichment and that was the AFD surface core collected in November $2011\left(\delta^{18} \mathrm{O}, 6.2\right.$; $\delta^{2} \mathrm{H},-54$ per mil). The ADRS plant-water signatures also were consistently more enriched than those observed for the Amargosa Flat sites. For example, the periodic-sample averages for ADRS creosote-bush $\delta^{18} \mathrm{O}$ and $\delta^{2} \mathrm{H}$ exceeded the AFS saltgrass averages by 5.9 and 27 per mil, respectively, and exceeded the overall AFI and AFD shadscale averages by 9.4 and 41 per mil, respectively. 
To gain additional insight into atmosphere-plant-soilgroundwater interactions in the Amargosa Flat study area, honey mesquite stem-water $\delta^{18} \mathrm{O}$ signatures were periodically determined for samples collected from a wash south of the AFS, AFI, and AFD sites and compared with those for water samples collected from wells within 24 hours of the stem sampling (fig. 4; table 12). In strong contrast to the other plants, mesquite was the only species to seem to acquire all of its water directly from the uptake of groundwater from the capillary fringe and (or) saturated zone. For example, the November $2011 \delta^{18} \mathrm{O}$ signature for trees along the wash (-13.8 per mil) closely matched that for groundwater $(-13.7$ per mil), whereas the signatures for trees at the other two locations ( -10.0 and -10.1 per mil) indicated they were obtaining at least some, if not all of their water from evaporatively enriched unsaturated-zone water. The mesquite signatures for these two locations are similar to those for the November 2011 AFI and AFD shadscale samples (-9.5 and -9.6 per mil, respectively; figs. $21 B$ and $21 C$ ) and associated soil-profile samples collected at the AFI 1.2-m depth ( -9.0 per mil) and the AFD 1.9-m depth (-9.7 per mil) (fig. 20A). The January-February 2012 mesquite-stem water data were not included in a source-water assessment because the samples were assumed to be affected by plant dormancy, nullifying their use as a tracer of active transpiration-stream water moving up through the plant. The May 2012 near-wash mesquite signature in table 12 is based on a single composite sample because the replicate value was anomalously high $(-2.4$ per mil) and resulted in a sample-pair coefficient of variation (CV) of 85 percent, which was much greater than those for all other dates (CVs $<7$ percent). The August 2012 stem-water signatures for the two bosque locations ( -14.6 and -14.1 per mil) reflect a direct and sole saturated-zone and (or) capillary fringe contribution, and the signature for the third location ( -9.6 per mil) indicates a large contribution from evaporatively enriched unsaturated-zone water. Although the results were not consistent among locations, it is of interest that the strongest groundwater signatures were measured in stem-waters collected during summer (August) and autumn (November) ( -14.6 to -13.8 per mil). The timing of these apparent increases in direct groundwater uptake may have corresponded with seasonal decreases in plant-available water in the unsaturated zone.

Table 12. Mean stable-isotope compositions of oxygen $\left(\delta^{18} 0\right)$ for honey mesquite-stem water sampled in a wash near the study sites and groundwater and cumulative precipitation from the study sites, Amargosa Flat, Nye County, Nevada, July 2011-August 2012.

[Mesquite locations include a bosque along a wash about 500 meters (m) south of Amargosa Flat Shallow (AFS), a bosque about $80 \mathrm{~m}$ northwest Amargosa Flat Intermediate (AFI), and a lone tree about $230 \mathrm{~m}$ southwest of the Amargosa Flat Deep (AFD) (fig. 4). Mesquite values represent the mean of two samples; groundwater and precipitation values represent the mean of samples from AFS, AFI, and AFD sites. -, not sampled]

\begin{tabular}{lcccc}
\hline \multirow{2}{*}{\begin{tabular}{c} 
Sample location \\
\multicolumn{1}{c}{ and type }
\end{tabular}} & \multicolumn{4}{c}{ Oxygen-18 (per mil) } \\
\cline { 2 - 5 } & $\begin{array}{c}\text { November 15-16, } \\
\text { 2011 }\end{array}$ & $\begin{array}{c}\text { January 31- } \\
\text { February 1, 2012 }\end{array}$ & $\begin{array}{c}\text { May 8-9, } \\
\mathbf{2 0 1 2}\end{array}$ & $\begin{array}{c}\text { August 28-30, } \\
\mathbf{2 0 1 2}\end{array}$ \\
\hline Bosque along wash south of AFS & -13.8 & $1-5.8$ & $2-9.7$ & -14.6 \\
Bosque northwest of AFI & -10.0 & 12.7 & -12.8 & -14.1 \\
Lone tree southwest of AFD & -10.1 & 112.7 & -12.9 & -9.6 \\
Groundwater & -13.7 & -13.8 & -13.7 & - \\
Cumulative precipitation & $3-4.6$ & $4-9.6$ & $5-11.8$ & $6-8.5$ \\
\hline
\end{tabular}

${ }^{1}$ Samples assumed to be affected by plant dormancy.

${ }^{2}$ Single sample.

${ }^{3}$ July-November 2011.

${ }^{4}$ November 2011-January 2012.

${ }^{5}$ January-May 2012.

${ }^{6}$ May-August 2012. 


\section{Comparisons of Evapotranspiration Estimates with Previous Estimates}

Compared with the results of this study, Nye County (T.S. Buqo, Nye County, written commun., 2006; Office of the State Engineer, 2007) overestimated GWET rates and area (see section, "Introduction”). The GWET rate estimated for the Amargosa Flat area $(150 \mathrm{~mm} / \mathrm{yr})$ is three to ten times greater than the GWET rates computed for AFS ( $50 \mathrm{~mm} / \mathrm{yr}$ ) or AFD (16 mm/yr). The GWET area was overestimated in part because groundwater depth was underestimated. For example, a groundwater depth of less than $3 \mathrm{~m}$ was estimated for the AFS and AFD sites where saturated-zone depths were 3.8 and $5.3 \mathrm{~m}$ bls, respectively. An accurate delineation of GWET area based on a less than $3 \mathrm{~m}$ groundwater depth would exclude the study area. Additionally, the GWET area was overestimated because the estimated greatest depth at which groundwater contributes to total ET $(15 \mathrm{~m})$ is substantially deeper than estimated for this study (6 m). The relation between AFS and AFD GWET rates and saturated-zone depths is shown in figure 22. If that line is extended by linear regression, the y-intercept indicates that GWET is 0 at a depth of $6 \mathrm{~m}$. However, the depth to the capillary fringe is considered a more accurate portrayal of subsurface conditions that can affect GWET than depth to the saturated zone. The relation between AFS and AFD GWET rates and depths to the top of the capillary fringe (AFS, $0.9 \mathrm{~m}$; AFD, $3.0 \mathrm{~m}$ ) also is shown in figure 22, and indicates that the greatest depth at which groundwater contributes to total ET is $4 \mathrm{~m}$. These results indicate that the delineated GWET area where groundwater depth is $3-15 \mathrm{~m}$ is overestimated because areas with groundwater depths greater than $6 \mathrm{~m}$ should be excluded.

In contrast, the results of this study also indicate that previous remote-sensing based approaches may have underestimated the areal extent of GWET areas because settings with surface features like those at AFS and AFD were not included in the mapped ET units (Laczniak and others (1999, 2001; fig. 3). The sparse cover of saltgrass at AFS is substantially less dense than the sparse saltgrass cover measured and classified by Laczniak and others $(1999,2001)$. Laczniak and others $(1999,2001)$ classified evapotranspiration units in Amargosa Desert by relating GWET rates measured at 10 representative sites to remotely sensed imagery using a process called spectral reflectance. The spectral-classification method is one of many remote-sensing techniques that attempt to identify and characterize vegetation on the basis of spectral reflectance. Results of this study suggest that these remotesensing methods are ineffective in areas with sparse vegetation where the ratio of green plant biomass to bare soil (plant cover) is low. The spectral reflectance of bare soil introduces background noise that confounds even methodologies designed to account for this effect. Accordingly, remotesensing methods are unable to differentiate areas like AFS from areas with no vegetation or sparse desert xerophytes, and the sparse cover and limited areal extent of saltgrass at AFS likely precluded it from inclusion in the sparse grassland ET unit. Future work to identify similar sparse-saltgrass areas may require costly ground-based vegetation surveys and supplemental remote-sensing work. The AFD study site was not within previously identified ET units because shadscale is classified as a xerophyte, which by definition is assumed to use only incident precipitation. However, results of this study indicate that the shadscale-dominant plant community at AFD contributed to the use of $16 \pm 15 \mathrm{~mm}$ of groundwater annually. Therefore, (1) the occurrence of xerophytes does not necessarily equate with the absence of groundwater discharge, and (2) the delineation of GWET zones based on vegetation surveys alone, which is the standard methodology for phreatophytic areas, could be problematic in xeric areas. These results are consistent with GWET estimate limitations described by Laczniak and others (1999, p. 48-49; and 2001, p. 31-35).

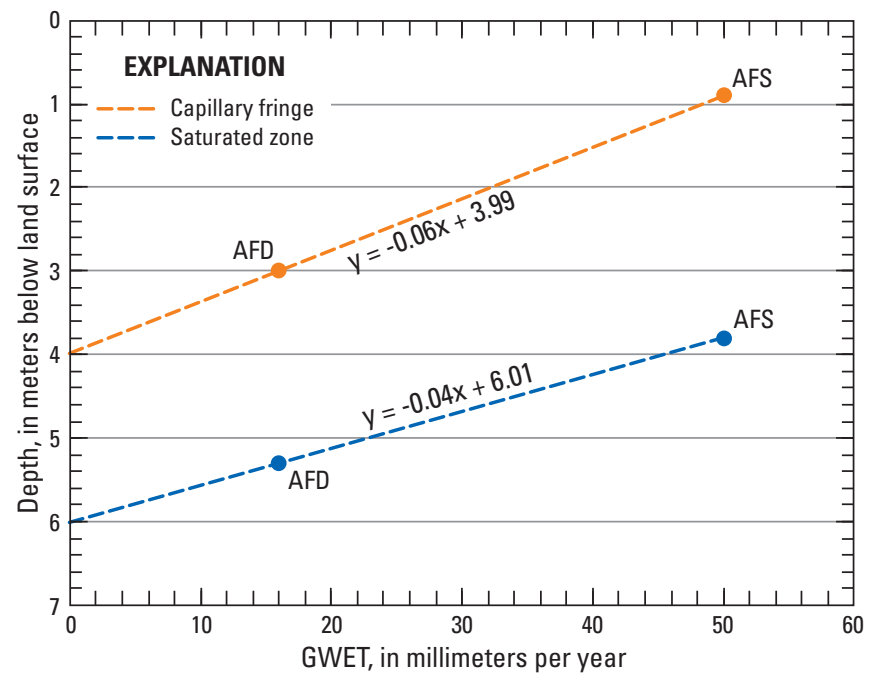

Figure 22. Groundwater evapotranspiration (GWET) as a function of capillary-fringe and saturated-zone depths, Amargosa Flat Shallow (AFS) and Amargosa Flat Deep (AFD) sites, Amargosa Desert, Nye County, Nevada, November 15, 2011, to November 14, 2013. 
Uncertainties can be introduced when GWET-area delineations are solely based on a depth-to-groundwater or surface-feature approach. Future mapping of GWET areas could benefit from an approach that incorporates a complementary set of supporting information that includes surface features (for example, plant type and density), depthto-groundwater, and unsaturated-zone data. The AFS and AFD unsaturated-zone results indicate how soil texture data can be used to estimate capillary-fringe heights, which results in a more complete characterization of subsurface conditions that can affect GWET. Soil texture also can be used to inform numerical modeling estimates of GWET. For example, a critical parameter in such modeling is the extinction depth, which is defined as the depth below which groundwater does not contribute to total ET (Shah and others, 2007). The extinction depth has traditionally been assigned as the base of the root zone, but new model formulations that assign the extinction depth to account for both the root-zone and a soiltexture based capillary-zone thickness yield more theoretically sound simulations of GWET (Ross and others, 2005). Sources of soil-texture information may include soil surveys, surficial geology maps, and drilling logs. In cases where supporting information is unavailable and difficult to accurately estimate, the cost-benefit of field-reconnaissance work will need to be considered.

\section{Summary and Conclusions}

Previous U.S. Geological Survey (USGS) studies have estimated groundwater discharge by evapotranspiration (GWET) in Amargosa Desert by measuring spring flow, evaporation, and evapotranspiration in areas populated by phreatophytic vegetation. These studies assumed that xeric areas characterized by xerophytic vegetation had no substantial groundwater discharge; however, more recent estimates by Nye County suggest that a substantial amount of groundwater does discharge from these xeric areas. In cooperation with Nye County and the U.S. Department of Energy, the USGS implemented a study to further evaluate GWET rates in sparsely vegetated areas of Amargosa Desert and to improve understanding of hydrologic-continuum processes controlling groundwater discharge through complementary analysis of saturated-zone, unsaturated-zone, and plant measurements.

A study area in Amargosa Flat was selected to investigate groundwater discharge processes in an area classified as having (1) no substantial groundwater loss by the USGS and (2) a GWET rate of 150 millimeters per year (mm/yr) by Nye County. Amargosa Flat GWET rates were determined by continuous eddy-covariance measurements at two instrumented sites over 2 years. Evapotranspiration and precipitation measurements were supplemented with continuous and periodic saturated-zone, unsaturated-zone, and stable-isotope measurements. One site (Amargosa Flat Shallow, AFS) was located in sparse saltgrass (Distichlis spicata (L.) Greene (Poaceae)) where the depth below land surface to the top of the saturated zone in the confined unit was 3.8 meters (m). The second site (Amargosa Flat Deep, AFD) was located in sparse shadscale (Atriplex confertifolia (Torr. \& Frem) S.Watson)) where the depth to the top of the saturated zone in the confined unit was $5.3 \mathrm{~m}$. The USGS Amargosa Desert Research Site (ADRS), where the depth to groundwater is $110 \mathrm{~m}$ and groundwater discharge is known to be zero, was used as a control or dry-benchmark site against which the Amargosa Flat results could be compared. The ADRS is located 50 kilometers from Amargosa Flat in sparse vegetation dominated by creosote bush (Larrea tridentata (DC.) Coville).

The mean annual (2 years) total evapotranspiration for AFS (135 mm/yr) was 32 percent greater than AFD (102 mm/yr) and 63 percent greater than ADRS (83 mm/yr). Amargosa Flat GWET rates were computed by subtracting precipitation from total evapotranspiration. Precipitation measured at both sites was nearly identical (AFS $=85 \mathrm{~mm} /$ $\mathrm{yr}, \mathrm{AFD}=86 \mathrm{~mm} / \mathrm{yr}$ ); accordingly, the mean annual GWET rate computed for AFS (50 \pm 20 millimeters [mm]) was about 3 times greater than for AFD $(16 \pm 15 \mathrm{~mm})$. These rates are roughly a tenth to a third the $150 \mathrm{~mm} / \mathrm{yr}$ estimated by Nye County for the Amargosa Flat study area.

Precise comparisons among results from the evapotranspiration, unsaturated-zone, and stable-isotope components of the study are not possible because each component targeted an independent set of measurements. However, results from unsaturated-zone and stable-isotopes of hydrogen and oxygen identified processes controlling groundwater discharge and provided strong support for the eddy-covariance-based site-to-site differences in GWET. First, the AFS and AFD soil-water potential and stable-isotope data showed that the input of groundwater into the unsaturated zone was driven by capillary rise and the fine-textured soil profiles (largely silt and clay) allowed the capillary fringe to extend up to within $0.9 \mathrm{~m}$ (AFS) and $3 \mathrm{~m}$ (AFD) of land surface. Second, between the top of the capillary fringe and land surface, the AFS and AFD soil-water potential gradients showed relatively persistent upward driving forces for unsaturated water flow, and the stable-isotope profiles confirmed that the evaporative loss of groundwater extended to 0.9-m (AFS) and 3-m (AFD) below land surface. In combination, these results indicated that the capillary fringe served as a subsurface reservoir that sustained and replenished the subsequent, slow but relatively persistent upward flow of water through the overlying unsaturated zone in response to atmospheric-evaporative demands. Recognizing that the ability of a soil to transmit water decreases rapidly with increasing depth to the water source and increasing soil dryness, the greater GWET reported for AFS compared with AFD sites corresponds with the shallower depth at AFS to the capillary fringe and persistently higher soil-moisture levels. For example, near-surface 
(0-0.75 m) soil-water contents measured during the 2-year study averaged 0.47 cubic centimeter per cubic centimeter $\left(\mathrm{cm}^{3} / \mathrm{cm}^{3}\right)$ for AFS compared with $0.20 \mathrm{~cm}^{3} / \mathrm{cm}^{3}$ for AFD. For completeness, these Amargosa Flat results can be broadly compared with conditions at the ADRS control site where GWET is zero, and the absence of groundwater discharge is supported by the great depth to groundwater $(110 \mathrm{~m})$ and typically dry near-surface profile $\left(0.05 \mathrm{~cm}^{3} / \mathrm{cm}^{3}\right)$.

Periodic measurement of stable-isotopic compositions in precipitation, plant water, unsaturated-zone water, and groundwater also provided insight into the water sources that contributed to plant-water uptake and loss by transpiration. The analyses included AFS saltgrass, AFD shadscale, Amargosa Flat study area mesquite, and ADRS creosote bush. Data for all four species showed how the water source and (or) depth of root-water uptake at a given location varies in response to changing environmental conditions. The stableisotope dataset presented in this report illustrates the broad range of plant-water-uptake scenarios that can occur in the Amargosa Desert. One endmember is the Amargosa Flat mesquite episodic, sole, and direct uptake of groundwater from the capillary fringe and (or) saturated zone. The other endmember is the ADRS persistent reliance of the creosote bush on the sole uptake of near-surface, precipitation-derived soil water. Intermediate scenarios include the mesquite, shadscale, and saltgrass species' time- and depth-variable uptake of unsaturated-zone water derived from combinations of precipitation and groundwater. The saltgrass and shadscale results are also noteworthy because they show that the simple presence of a certain type of plant is not a definitive indicator of subsurface hydrologic processes. For example, saltgrass is broadly classified as a phreatophyte which implies the direct uptake of groundwater from the capillary fringe or the saturated zone, but such direct uptake was not observed for the AFS saltgrass. Likewise, shadscale is broadly classified as a xeric shrub, which suggests sole reliance on incident precipitation for survival, but this study showed that water uptake by AFD shadscale included use of groundwater released from the capillary fringe.

Broad extrapolation of the AFS and AFD GWET rates to other areas of Amargosa Desert is beyond the scope of this work, but the overall findings are pertinent to future largescale mapping and assessment of GWET. For example, the AFS and AFD unsaturated-zone results indicate how soil texture data can be used to estimate capillary-fringe heights and how this led to a more accurate characterization of subsurface conditions controlling GWET. Future mapping of GWET areas could benefit from an expanded approach that incorporates soil-texture information along with typical surface-features (for example, plant type and density) and depth-to-groundwater information. In addition to the fieldbased GWET estimates reviewed and presented in this report, soil texture information can be important to numerical modeling estimates of GWET. For example, a critical parameter in such modeling is the extinction depth, which is defined as the depth below which groundwater does not contribute to total evapotranspiration. Data from the present study indicate model formulations that assign the extinction depth to account for both the root-zone and a soil-texture based capillary-zone thickness are likely to yield more theoretically sound simulations of GWET.

\section{Acknowledgments}

The authors wish to thank the Nye County Board of Commissioners, Darrell Lacy, Levi Kryder, and John Klenke for supporting this research effort, Tim Jacobs and Industrial Mineral Ventures Nevada for generously allowing access to private land, and Boris Poff from the Bureau of Land Management Las Vegas Field Office for spearheading the permit process. We are particularly grateful to the late Tom Buqo for advocating this study and for many hours of spirited debate.

We also wish to thank the following past and present USGS employees who contributed in many ways to the completion of this study: Jonathan Arthur, Dan Bright, Steve Crawford, Bill Dam, Jon Darnell, Chris Evans, Rebecca Frus, Phil Gardner, Debra Grillo, Jim Huckaby, Leigh Justet, Randy Laczniak, Todd Menning, Geoff Moret, Erin Orozco, Linda Rogers, David Smith, Michelle Stern, Dave Stonestrom, and Bonnie Thompson.

\section{References Cited}

Allander, K.K, Smith, J.L, and Johnson, M.J., 2009, Evapotranspiration from the Lower Walker River basin, west-central Nevada, water years 2005-07, U.S. Geological Survey Scientific Investigations Report 2009-5079, 62 p., http://pubs.er.usgs.gov/publication/sir20095079.

Alpert, P., 1990, Water sharing among ramets in a desert population of distichlis spicata (Poaceae): American Journal of Botany, v. 77, no. 12, p. 1,648-1,651.

Andraski, B.J, 1996, Properties and variability of soil and trench fill at an arid waste-burial site: Soil Science Society of America Journal, v. 60, no. 1, p. 54-66.

Andraski, B.J., 1997, Soil-water movement under natural-site and waste-site conditions-A multiple-year field study in the Mojave Desert, Nevada: Water Resources Research, v. 33, no. 9, p. 1,901-1,916.

Andraski, B.J., and Jacobson, E.A., 2000, Testing a full-range soil-water retention function in modeling water potential and temperature: Water Resources Research, v. 36, no. 10, p. 3,081-3,089, doi: 10.1029/2000WR9001932000. 
Andraski, B.J., and Prudic, D.E., 1997, Soil, plant, and structural considerations for surface barriers in arid environments-Application of results from studies in the Mojave Desert near Beatty, Nevada, in Barrier Technologies for Environmental Management, Summary of a Workshop: Washington, D.C., National Academy Press, p. D50-D60.

Andraski, B.J., and Scanlon, B.R., 2002, Thermocouple psychrometry, in Dane, J.H., and Topp, G.C., eds., Methods of soil analysis-Part 4, Physical methods: Madison, Wisconsin, Soil Science Society of America, p. 609-642.

Ardiansyah, Shiozawa, S., and Nishida, K., 2008, Thermal properties and shrinkage-swelling characteristic of clay soil in a tropical paddy field: Journal of the Japanese Society of Soil Physics, v. 110, p. 67-77.

Arthur, J.M., Johnson, M.J., Mayers, C.J., and Andraski, B.J., 2012, Micrometeorological, evapotranspiration, and soilmoisture data at the Amargosa Desert Research site in Nye County near Beatty, Nevada, 2006-11: U.S. Geological Survey Data Series 725, 12 p., http://pubs.er.usgs.gov/ publication/ds725.

Baldocchi, D.D., 2003, Assessing the eddy covariance technique for evaluating carbon dioxide exchange rates of ecosystems: past, present, and future: Global Change Biology, v. 9, no. 4, p. 479-492.

Barnes, C.J, and Allison, G.B., 1988, Tracing of water movement in the unsaturated zone using stable isotopes of hydrogen and oxygen: Journal of Hydrology, v. 100, p. 143-176.

Berger, D.L., Mayers, C.J., Garcia, C.A., Buto, S.G., and Huntington, J.M., 2016, Budgets and chemical characterization of groundwater for the Diamond Valley flow system, central Nevada, 2011-12: U.S. Geological Survey Scientific Investigations Report 2016-5055, 83 p., http://dx.doi.org/10.3133/sir20165055.

Blaney, H.F., Taylor, C.A., Nickle, H.G., and Young, A.A., 1933, Water losses under natural conditions from wet areas in southern California: California Department of Public Works, Division of Water Resources Bulletin 44, 176 p.

Blonquist, J.M., Jr., Tanner, B.D., and Bugbee, B., 2009, Evaluation of measurement accuracy and comparison of two new and three traditional net radiometers: Agricultural and Forest Meteorology, v. 149, p. 1,709-1,721.

Branson, F.A., Miller, R.F., and McQueen, I.S., 1976, Moisture relationships in twelve northern desert shrub communities near Grand Junction, Colorado: Ecology, v. 57 , no. 6 , p. $1,104-1,124$.

Bredehoeft, J., 2007, It is the discharge: Groundwater, v. 45, no. 5, p. 523-523.
Brotzge, J.A., and Duchon, C.E., 2000, A field comparison among a domeless net radiometer, two four-component net radiometers, and a domed net radiometer: Journal of Atmospheric and Oceanic Technology, v. 17, p. $1,569-1,582$.

Bruand, A., and Tessier, D., 2000, Water retention properties of the clay in soils developed on clayey sedimentsSignificance of parent material and soil history: European Journal of Soil Science, v. 51, p. 679-688.

Brutsaert, W.H., 1982, Evaporation into the atmosphere: Boston, Mass., D. Reidel Publishing, 299 p.

Campbell, G.S., 1985, Soil physics with BASIC-Transport models for soil-plant systems: Amsterdam, Elsevier Science Publishers, $150 \mathrm{p}$.

Campbell, G.S., and Norman, J.M., 1998, An introduction to environmental biophysics (2d ed.): New York, SpringerVerlag New York, Inc., 286 p.

Campbell Scientific, Inc., 2009, CNR2 net radiometer, revision 10/09: Logan, Utah, Campbell Scientific, Inc. instruction manual, accessed January 8, 2010, at https://s.campbellsci. com/documents/cn/manuals/cnr2.pdf.

Campbell Scientific, Inc., 2010a, KH2O krypton hygrometer, revision 2/10: Logan, Utah, Campbell Scientific, Inc. instruction manual, accessed December 23, 2010, at https://s.campbellsci.com/documents/us/manuals/kh20.pdf.

Campbell Scientific, Inc., 2010b, CSAT3 three dimensional sonic anemometer, revision 6/10: Logan, Utah, Campbell Scientific, Inc. instruction manual, accessed September 28, 2011, at http://s.campbellsci.com/documents/us/manuals/ csat3.pdf.

Campbell Scientific, Inc., 2012, HFP01 soil heat flux plate, revision 7/12: Logan, Utah, Campbell Scientific, Inc. instruction manual accessed May 1, 2014, at http://s. campbellsci.com/documents/us/manuals/hfp01.pdf.

Chimner, R.A., and Cooper, D.J., 2004, Using stable oxygen isotopes to quantify the water source used for transpiration by native shrubs in the San Luis Valley, Colorado U.S.A.: Plant and Soil, v. 260, nos. 1-2, p. 225-236.

Clement, R., 1999, EdiRe data software: University of Edinburgh, ver. 1.5.0.10, at http://www.geos.ed.ac.uk/abs/ research/micromet/EdiRe/.

Craig, H., and Gordon, L.I., 1965, Deuterium and oxygen 18 variations in the ocean and the marine atmosphere, in Tongiogi, E., ed., Stable Isotopes in Oceanographic Studies and Paleotemperatures, 1965, Proceedings: Spoleto, Italy, V. Lishi e F., Pisa, p. 9-130. 
Crofts, K.A., and Van Epps, Gordon, 1975, The usefulness of shadscale in the revegetation of disturbed sites in the salt desert shrub type, in Wildland Shrubs, Proceedings of Symposium and Workshop: Provo, Utah, U.S. Forest Service Shrub Sciences Laboratory, p. 151-152.

DeMeo, G.A., Laczniak, R.J., Boyd, R.A., Smith, J.L., and Nylund, W.E., 2003, Estimated ground-water discharge by evapotranspiration from Death Valley, California, 1997-2001: U.S. Geological Survey Water-Resources Investigations Report 2003-4254, 27 p., http://pubs.er.usgs. gov/publication/wri034254.

Ehleringer, J.R., and Dawson, T.E., 1992, Water uptake by plants-Perspective from stable isotope composition: Plant, Cell, and Environment, v. 15, p. 1,073-1,082.

Ehleringer, J.R., Phillips, S.L., Schuster, W.S.F., and Sandquist, D.R., 1991, Differential utilization of summer rains by desert plants: Oecologia, v. 88, no. 3, p. 430-434.

Ellsworth, P.Z., and Williams, D.G., 2007, Hydrogen isotope fractionation during water uptake by woody xerophytes: Plant Soil, v. 291, p. 93-107.

Fayer, M.J., 2000, UNSAT-H Version 3.0 Unsaturated Soil Water and Heat Flow Model-Theory, user manual, and examples: Pacific Northwest National Laboratory Report PNNL-13249, 184 p.

Fenelon, J.M., Halford, K.J., and Moreo, M.T., 2016, Delineation of the Pahute Mesa-Oasis Valley groundwater basin, Nevada (ver. 1.1, May 2016): U.S. Geological Survey Scientific Investigations Report 2015-5175, 40 p., http:// dx.doi.org/10.3133/sir20155175.

Fenelon, J.M., and Moreo, M.T., 2002, Trend analysis of ground-water levels and spring discharge in the Yucca Mountain region, 1960-2000: U.S. Geological Survey Water-Resources Investigations Report 02-4178, 97 p., http://pubs.usgs.gov/wri/wrir024178/.

Fernandez, O.A, and Caldwell, M.M, 1975, Phenology and dynamics of root growth of three cool semi-desert shrubs under field conditions: Journal of Ecology, v. 63, no. 2, p. 703-714.

Fetter, C.W., 1980, Applied hydrogeology: Columbus, Ohio, Charles E. Merrill Publishing Co., 488 p.

Fischer, J.M., 1992, Sediment properties and water movement through shallow unsaturated alluvium at an arid site for disposal of low-level radioactive waste near Beatty, Nye County, Nevada: U.S. Geological Survey Water-Resources Investigations Report 92-4032, 48 p., http://pubs.er.usgs. gov/publication/wri924032.
Flint, A.L., Campbell, G.S., Ellet, K.M., and Calissendorff, C., 2002, Calibration and temperature correction of heat dissipation matric potential sensors: Soil Science Society of America Journal, v. 66, no. 5, p. 1,439-1,445.

Foken, T., 2008, Micrometeorology: Springer-Verlag Berlin Heidelberg, 306 p.

Foken, T., Leuning, R., Oncley, S., Mauder, M., and Aubinet, M., 2012, Corrections and data quality control, chapter 4 of Aubinet, M., Vesala, T., and Papale, D., eds., Eddy covariance-A practical field guide to measurement and data analysis: Springer Dordrecht Heidelberg London New York, 438 p.

Garcia, C.A., Andraski, B.J., Stonestrom, D.A., Cooper, C.A., Johnson, M.J., Michel, R.L., and Wheatcraft, S.W., 2009, Transport of tritium contamination from the shallow unsaturated zone to the atmosphere in an arid environment: Vadose Zone Journal, v. 8, no. 2, p. 450-461.

Garcia, C.A., Andraski, B.J., Stonestrom, D.A., Cooper, C.A., Simunek, J., and Wheatcraft, S.W., 2011, Interacting vegetative and thermal contributions to water movement in desert soil: Vadose Zone Journal, v. 10, no. 2, p. 552-564.

Garcia, C.A., Huntington, J.M., Buto, S.G., Moreo, M.T., Smith, J.L., and Andraski, B.J., 2014, Groundwater discharge by evapotranspiration, Dixie Valley, west-central Nevada, March 2009-September 2011: U.S. Geological Survey Professional Paper 1805, 90 p., http://dx.doi. org/10.3133/pp1805.

Gardner, W.R., 1958, Some steady state solutions of the unsaturated moisture flow equation with application to evaporation from a water table: Soil Science, v. 85, no. 4, p. 228-232.

Gee, G.W., and Bauder, J.W., 1986, Particle-size analysis, in Klute, Arnold, ed., Methods of soil analysis-Part 1, Physical and mineralogical methods (2d ed.): Madison, Wisconsin, American Society of Agronomy and Soil Science Society of America, p. 255-293.

Gile, L.H., Gibbens, R.P., and Lenz, J.M., 1998, Soil-induced variability in root systems of creosotebush (Larrea tridentata) and tarbush (Flourensia cernua): Journal of Arid Environments, v. 39, p. 57-78.

Hauser, A.S., 2006, Distichlis spicata in Fire Effects Information System: U.S. Department of Agriculture, Forest Service, Rocky Mountain Research Station, Fire Sciences Laboratory, accessed June 9, 2015, at http://www.fs.fed.us/ database/feis/.

Hignett, Cliff, and Evett, S.R., 2002, Neutron thermalization, in Dane, J.H., and Topp, G.C., eds., Methods of soil analysis_-Part 4, Physical methods: Madison, Wisconsin, Soil Science Society of America, p. 501-521. 
Højstrup, J., 1993, A statistical data screening procedure: Measurement Science and Technology, v. 4, p. 153-157.

Johnson, M.J., Mayers, C.J., Garcia, C.A., and Andraski, B.J., 2007, Selected micrometeorological, soil-moisture, and evapotranspiration data at Amargosa Desert Research Site in Nye County near Beatty, Nevada, 2001-05: U.S. Geological Survey Data-Series Report 284, 29 p., http://pubs.usgs.gov/ ds/2007/284.

Kaimal, J.C., and Finnigan, J.J., 1994, Atmospheric boundary layer flows, their structure and measurement: New York, Oxford University Press, 289 p.

Kampf, S.K., Tyler, S.W., Ortiz, C.A., Muñoz, J.F., and Adkins, P.L., 2005, Evaporation and land surface energy budget at the Salar de Atacama, northern Chile: Journal of Hydrology, v. 310, nos. 1-4, p. 236-252.

Khaleel, R., Relyea, J.F., and Conca, J.L., 1995, Evaluation of van Genuchten-Mualem relationships to estimate unsaturated hydraulic conductivity at low water contents, Water Resources Research, v. 31, p. 2,659-2,668.

Klute, Arnold, 1986, Water retention: Laboratory methods, in Klute, Arnold, ed., Methods of soil analysis-Part 1, Physical and mineralogical methods (2d ed.): Madison, Wisconsin, American Society of Agronomy and Soil Science Society of America, p. 635-662.

Klute, Arnold, and Dirksen, C., 1986, Hydraulic conductivity and diffusivity—Laboratory methods, in Klute, Arnold, ed., Methods of soil analysis-Part 1, Physical and mineralogical methods (2d ed.): Madison, Wisconsin, American Society of Agronomy and Soil Science Society of America, p. 687-734.

Koorevaar, P., Menelik, G., and Dirksen, C., 1983, Elements of soil physics: Amsterdam, Elsevier Science Publishers, $230 \mathrm{p}$.

Kormann, R., and Meixner, F., 2000, An analytical footprint model for non-neutral stratification: Boundary-Layer Meteorology, v. 99, no. 2, p. 207-224.

Laczniak, R.J., DeMeo, G.A., Reiner, S.R., Smith, J.L., and Nylund, W.E., 1999, Estimates of ground-water discharge as determined from measurements of evapotranspiration, Ash Meadows area, Nye County, Nevada: U.S. Geological Survey Water-Resources Investigations Report 99-4079, 70 p., http://pubs.er.usgs.gov/publication/wri994079.
Laczniak, R.J., Flint, A.L., Moreo, M.T., and others, 2007, Ground-water budgets in Welch, A.H., Bright, D.J., and Knochenmus, L.A., eds., Water resources of the Basin and Range carbonate-rock aquifer system, White Pine County, Nevada, and adjacent areas in Nevada and Utah: U.S. Geological Survey Scientific Investigations Report 2007-5261, p. 43-82, http://pubs.er.usgs.gov/publication/ sir20075261.

Laczniak, R.J., Smith, J.L., and DeMeo, G.A., 2006, Annual ground-water discharge by evapotranspiration from areas of spring-fed riparian vegetation along the eastern margin of Death Valley, 2000-02: U.S. Geological Survey Scientific Investigations Report 2006-5145, 36 p., http://pubs.er.usgs. gov/publication/sir20065145.

Laczniak, R.J., Smith, J.L., Elliot, P.E., DeMeo, G.A., Chatigny, M.A., and Roemer, G.J., 2001, Ground-water discharge determined from estimates of evapotranspiration, Death Valley regional flow system, Nevada and California: U.S. Geological Survey Water-Resources Investigations Report 01-4195, 51 p., http://pubs.er.usgs.gov/publication/ wri014195.

Larsen, L.W., and Peck, E.L., 1974, Accuracy of precipitation measurements for hydrologic modeling: Water Resources Research, v. 10, no. 4, p. 857-863.

Law, B.E., Loescher, H.W., Boden, T.A., Hargrove, W.W., and Hoffman, F.M., 2005, AmeriFlux site evaluation and recommendations for network enhancement: Oak Ridge National Laboratory, accessed May 5, 2014, at: http:// public.ornl.gov/ameriflux/AmeriFluxSiteEvaluationWEB. pdf.

Lee, C.H., 1912, An intensive study of the water resources of a part of Owens Valley, California: U.S. Geological Survey Water-Supply Paper 294, 135 p., http://pubs.er.usgs.gov/ publication/wsp294.

Leuning, R., van Gorsel, E., Massman, W.J., and Isaac, P.R., 2012, Reflections on the surface energy imbalance problem: Agricultural and Forest Meteorology, v. 156, p. 65-74.

Lin, G.L, and Sternberg, L. da S.L., 1993, Hydrogen isotopic fractionation by plant roots during water uptake in coastal wetland plants, in Ehleringer, J.R., and others, eds., Stable isotopes and plant carbon-water relations: San Diego, CA, Academic Press, p. 497-510.

Lohman, S.W., Bennett, R.R., Brown, R.H., Cooper, Jr., H.H., Drescher, W.J., Ferris, J.G., Johnson, A.I., McGuinness, C.L., Piper, A.M., Rorabaugh, M.I., Stallman, R.W., and Theis, C.V., 1972, Definitions of selected groundwater terms - revisions and conceptual refinements: U.S. Geological Survey Water-Supply Paper 1988, 21 p., https:// pubs.er.usgs.gov/publication/wsp1988. 
Mayers, C.J., Andraski, B.J., Cooper, C.A., Wheatcraft, S.W., Stonestrom, D.A., and Michel, R.L., 2005, Modeling tritium transport through a deep unsaturated zone in an arid environment: Vadose Zone Journal, v. 4, p. 967-976, doi:10.2136/vzj2004.01792005.

Meinzer, O.E., 1927, Plants as indicators of ground water: U.S. Geological Survey Water-Supply Paper 577, 95 p., http://pubs.er.usgs.gov/publication/wsp577.

Millington, R.J., and Quirk, J.P., 1960, Transport in porous media, in Van Beren, F.A., and others, eds., Transactions of the International Congress of Soil Science, 7th: Amsterdam, Elsevier, v. 1, p. 97-106.

Milly, P.C., 1996, Effects of thermal vapor diffusion on seasonal dynamics of water in the unsaturated zone: Water Resources Research, v. 32, p. 509-518.

Moore, C.J., 1986, Frequency response corrections for eddy correlation systems: Boundary-Layer Meteorology, v. 37, p. 17-35.

Moreo, M.T., Andraski, B.J., and Garcia, C.A., 2017, Evapotranspiration, groundwater, and unsaturated-zone data, Amargosa Desert, Nye County, Nevada, 2011-13: U.S. Geological Survey data release, http://dx.doi. org/10.5066/F7R49NZN.

Moreo, M.T., Laczniak, R.J., and Stannard, D.I., 2007, Evapotranspiration rate estimates of vegetation typical of ground-water discharge areas in the Basin and Range Carbonate-Rock aquifer system, Nevada and Utah, September 2005-August 2006: U.S. Geological Survey Scientific Investigations Report 2007-5078, 36 p., http:// pubs.er.usgs.gov/publication/sir20075078.

Moreo, M.T., Senay, G.B., Flint, A.L., Damar, N.A., Laczniak, R.J., and Hurja, James, 2014, Hydroclimate of the Spring Mountains and Sheep Range, Clark County, Nevada: U.S. Geological Survey Scientific Investigations Report 20145142, 38 p., https://pubs.usgs.gov/sir/2014/5142/.

Nachshon, U., Weisbrod, N., Dragila, M., and Grader, A., 2011, Combined evaporation and salt precipitation in homogeneous and heterogeneous porous media: Water Resources Research, v. 47, W03513, doi:10.1029/2010WR009677.

Nichols, W.D., 1994, Groundwater discharge by phreatophyte shrubs in the Great Basin as related to depth to groundwater: Water Resources Research, v. 30, no. 12, p. 3,265-3,274.

Odening, W.R., Strain, B.R., and Oechel, W.C., 1974, The effect of decreasing water potential on net $\mathrm{CO}_{2}$ exchange of intact desert shrubs, Ecology, v. 55, p. 1,086-1,095.
Office of the State Engineer, 2007, Ruling \#5750: Nevada Division of Water Resources, 22 p., http://images.water. nv.gov/images/rulings/5750r.pdf.

Philip, J.R., and de Vries, D.A., 1957, Moisture movement in porous materials under temperature gradient: Transactions of the American Geophysical Union, no. 38, p. 222-232.

Phillips, F.M., 1994, Environmental tracers for water movement in desert soils of the American Southwest: Soil Science Society of America Journal, v. 58, no. 1, p. 15-24.

Prior-Magee, J.S., Boykin, K.G., Bradford, D.F., Kepner, W.G., Lowry, J.H., Schrupp, D.L., Thomas, K.A., and Thompson, B.C., eds., 2007, Ecoregional gap analysis of the southwestern United States-The Southwest Regional Gap Analysis Project final report: Moscow, Idaho, U.S. Geological Survey Gap Analysis Program, 441 p., http://swregap.nmsu.edu/report/SWReGAP\%20Final\%20 Report.pdf.

Rannik, U., Sogachev, A., Foken, T., Gockede, M., Kljun, N., Leclerc, M., and Vesala, T., 2012, Footprint analysis chapter 8 of Aubinet, M., Vesala, T., Papale, D., eds., Eddy covariance-A practical field guide to measurement and data analysis: Springer Dordrecht Heidelberg London New York, $438 \mathrm{p}$.

Reiner, S.R., Laczniak, R.J., DeMeo, G.A., Smith, J.L., Elliott, P.E., Nylund, W.E., and Fridrich, C.J., 2002, Ground-water discharge determined from measurements of evapotranspiration, other available hydrologic components, and shallow water-level changes, Oasis Valley, Nye County, Nevada: U.S. Geological Survey Water-Resources Investigations Report 01-4239, 65 p., http://pubs.er.usgs. gov/publication/wri014239.

Révész, K., and Woods, P.H., 1990, A method to extract soil water for stable isotope analysis: Journal of Hydrology, v. 115 , nos. $1-4$, p. 397-406.

Rhoades, J.D., 1986, Soluble salts, in Page, A.L., and others, eds., Methods of soil analysis-Part 2, Chemical and microbiological properties (2d ed.): Madison, Wisconsin, American Society of Agronomy and Soil Science Society of America, p. 167-179.

Robinson, T.W., 1958, Phreatophytes: U.S. Geological Survey Water Supply Paper 1423, 84 p., http://pubs.er.usgs.gov/ usgspubs/wsp/wsp1423.

Ross, Mark, Geurink, Jeffrey, Said, Ahmed, Aly, Alaa, and Tara, Patrick, 2005. Evapotranspiration conceptualization in the HSPF-MODFLOW integrated models: Journal of the American Water Resources Association, v. 41, p. 1,013-1,025. 
Scanlon, B.R., Andraski, B.J., and Bilskie, Jim, 2002, Miscellaneous methods for measuring matric or water potential, in Dane, J.H., and Topp, G.C., eds., Methods of soil analysis-Part 4, Physical methods: Madison, Wisconsin, Soil Science Society of America, p. 643-670.

Scanlon, B.R., Keese, Kelly, Reedy, R.C., J. Šimůnek, Jirka, and Andraski, B.J., 2003, Variations in flow and transport in thick desert vadose zones in response to paleoclimatic forcing (0-90 kyr)—Field measurements, modeling, and uncertainties: Water Resources Research, v. 39, no. 7, 1,179 p., doi:10.1029/2002WR001604.

Schirmer, Ute, and Breckle, S.W., 1982, The role of bladders for salt removal in some Chenopodiaceae (mainly Atriplex species), chapter 8 of Sen, D.N., and Rajpurohit, K.S., eds., Tasks for vegetation science, vol. 2-Contributions to the ecology of halophytes: The Hague, The Netherlands, Dr W. Junk Publishers, p. 215-231.

Schotanus, P., Nieuwstadt, F.T.M., and de Bruin, H.A.R., 1983, Temperature measurement with a sonic anemometer and its application to heat and moisture fluxes: BoundaryLayer Meteorology, v. 50, p. 81-93.

Schuepp, P.H., LeClerc, M.Y., Macpherson, J.I., and Desjardins, R.L., 1990, Footprint prediction of scalar fluxes from analytical solutions of the diffusion equation: Boundary-Layer Meteorology, v. 50, p. 355-373.

Scott, R.L., Williams, D.G., Goodrich, D.C., Cable, W.L., Levick, L.R., McGuire, R., Gazal, R.M., Yepez, E.A., Ellsworth, P., and Huxman, T.E., 2005, Determining the riparian ground-water use within the San Pedro Riparian National Conservation Area and the Sierra Vista subwatershed, Arizona, chap. D of Leenhouts, J.M., Stromberg, J.C., and Scott, R.L., Hydrologic requirements of and consumptive ground-water use by riparian vegetation along the San Pedro River, Arizona: U.S. Geological Survey Scientific Investigations Report 2005-5163, 154 p., http:// pubs.usgs.gov/sir/2005/5163/.

Shah, N., Nachabe, M., and Ross, M., 2007, Extinction depth and evapotranspiration from ground water under selected land covers: Ground Water, v. 45, p. 329-338.

Shahraeeni, E., and Or, D., 2012, Pore scale mechanisms for enhanced vapor transport through partially saturated porous media: Water Resources Research, v. 48, W05511, doi:10.1029/2011WR011036, 16 p.

Shokri, N., Lehmann, P., and Or, D., 2009, Critical evaluation of enhancement factors for vapor transport through unsaturated porous media, Water Resources Research, v. 45, W10433, doi:10.1029/2009WR007769.

Smith, R.L., 1974, Ecology and field biology (2d ed.): New York, Harper and Row, 850 p.
Smith, S.D., Monson, R.K., and Anderson, J.E., 1997, Physiological ecology of North American desert plants: Springer-Verlag, Berlin, 288 p.

Soil Survey Staff, Natural Resources Conservation Service, 2014, Web soil survey: Natural Resources Conservation Service Web site, accessed October 2, 2014, http:// websoilsurvey.nrcs.usda.gov/.

Stannard, D.I., Blanford, J.H., Kustas, W.P., Nichols, W.D., Amer, S.A., Schmugge, T.J., and Welz, M.A., 1994, Interpretation of surface flux measurements in heterogeneous terrain during the Monsoon '90 experiment: Water Resources Research, v. 30, no. 5, p. 1,227-1,239.

Stannard, D.I., Gannett, M.W., Polette, D.J., Cameron, J.M., Waibel, M.S., and Spears, J.M., 2013, Evapotranspiration from marsh and open-water sites at Upper Klamath Lake, Oregon, 2008-2010: U.S. Geological Survey Scientific Investigations Report 2013-5014, 66 p., https://pubs.usgs. gov/sir/2013/5014/.

Steinberg, P, 2001, Prosopis glandulosa in Fire Effects Information System: U.S. Department of Agriculture, Forest Service, Rocky Mountain Research Station, Fire Sciences Laboratory (Producer), accessed June 12, 2015, at http:// www.fs.fed.us/database/feis/.

Stonestrom, D.A., Prudic, D.E., Laczniak, R.J., Akstin, K.C., Boyd, R.A., and Henkelman, K.K., 2003, Estimates of deep percolation beneath native vegetation, irrigated fields, and the Amargosa-River channel, Amargosa Desert, Nye County, Nevada: U.S. Geological Survey Open-File Report 2003-104, 88 p.

Stonestrom, D.A., Prudic, D.E., Walvoord, M.A., Abraham, J.D., Stewart-Deaker, A.E., Glancy, P.A., Constantz, J., Laczniak, R.J., and Andraski., B.J., 2007, Focused ground-water recharge in the Amargosa Desert Basin, in Stonestrom, D.A., Constantz, J., Ferre, T.P.A., and Leake, SA., eds., Ground-water recharge in the arid and semiarid southwestern United States: U.S. Geological Survey Professional Paper 1703-E, p. 107-136, http://pubs. usgs.gov/pp/pp1703/e.

Swinbank, W.C., 1951, The measurement of vertical transfer of heat and water vapor by eddies in the lower atmosphere: Journal of Meteorology, v. 8, no. 3, p. 135-145.

Tanner, B.D., and Greene, J.P., 1989, Measurement of sensible heat and water-vapor fluxes using eddy-correlation methods: Final report prepared for U.S. Army Dugway Proving Grounds, U.S. Army, 17 p.

Taylor, E.M., and Sweetkind, D.S., 2014, Three-dimensional geologic mapping of the Cenozoic basin fill, Amargosa Desert Basin, Nevada and California: U.S. Geological Survey Scientific Investigations Report 2014-5003, 40 p., 2 apps., http://dx.doi.org/10.3133/sir20145003. 
Taylor, J.R., 1997, Error analysis-The study of uncertainties in physical measurements: Sausalito, California, University Science Books, 327 p.

Thomas, J.M., Welch, A.H., and Dettinger, M.D, 1996, Geochemistry and isotope hydrology of representative aquifers in the Great Basin region of Nevada, Utah, and adjacent states: U.S. Geological Survey Professional Paper 1409-C, 100 p., http://pubs.er.usgs.gov/publication/ pp1409C.

Twine, T.E., Kustas, W.P., Norman, J.M., Cook, D.R., Houser, P.R., Meyers, T.P., Prueger, J.H., Starks, P.J., and Wesely, M.L., 2000, Correcting eddy-covariance flux underestimates over a grassland: Agricultural and Forest Meteorology, v. 103, p. 279-300.

Tyler, S.W., Chapman, J.B., Conrad, S.H., Hammermeister, D.P., Blout, D.O., Miller, J.J., Sully, M.J., and Gianni, J.M., 1996, Soil-water flux in the southern Great Basin, United States: Temporal and spatial variations over the last 120,000 years: Water Resources Research, v. 32, no. 6, p. 1,481-1,499.

U.S. Geological Survey, 2014, Water-resources data for the United States, water year 2013: U.S. Geological Survey Water-Data Report WDR-US-2013, sites 364556116413501 and 364556116413701: U.S. Geological Survey database, accessed December 17, 2015, at http://wdr.water.usgs.gov/ wy2013/pdfs/364556116413501.2013.pdf and http://wdr. water.usgs.gov/wy2013/pdfs/364556116413701.2013.pdf.

van Genuchten, M., Th., 1980, A closed-form equation for predicting the hydraulic conductivity of unsaturated soils: Soil Science Society of America Journal, v. 44, no. 5, p. 892-898, doi.10.2136/sssaj1980.036159950044000500 02x.

Walker, G.E., and Eakin, T.E., 1963, Geology and ground water of Amargosa Desert, Nevada-California: Nevada Department of Conservation and Natural Resources, Ground-Water Resources-Reconnaissance Report 14, 45 p.

Walvoord, M.A., Phillips, F.M., Tyler, S.W., and Hartsough, P.C., 2002, Deep system hydrodynamics-Part 2 Application to paleohydrologic reconstruction using vadose-zone profiles from the northern Mojave Desert: Water Resources Research, v. 38, no. 12, p. 27-1-27-12, doi:10.1029/2001WR000825.

Walvoord, M.A., Stonestrom, D.A., Andraski, B.A., and Striegl, R.G., 2004, Constraining the inferred paleohydrologic evolution of a deep unsaturated zone in the Amargosa Desert: Vadose Zone Journal, v. 3, p. 502-512.
Webb, E.K., Pearman, G.I., and Leuning, R., 1980, Correction of flux measurements for density effects due to heat and water vapour transfer: Quarterly Journal of the Royal Meteorological Society, v. 106, p. 85-100.

White, J.W.C., Cook, E.R., Lawrence, J.R., and Broecker, W.S., 1985, The D/H ratios of sap in trees-Implications for water sources and tree ring $\mathrm{D} / \mathrm{H}$ ratios: Geochimica et Cosmochimica Acta, v. 49, p. 237-246.

White, W.N., 1932, A method of estimating ground-water supplies based on discharge by plants and evaporation from soil-Results of investigations in Escalante Valley, Utah, in Contributions to the hydrology of the United States 1932: U.S. Geological Survey Water-Supply Paper 659-A, 105 p., 1 pl., https://pubs.er.usgs.gov/publication/wsp659A.

Wilson, K., Goldstein, A., Falge, E., Aubinet, M., Baldocchi, D., Berbigier, P., Bernhofer, C., Ceulemans, R., Dolman, H., Field, C., Grelle, A., Ibrom, A., Law, B., Kowalski, A., Meyers, T., Moncrieff, J., Monson, R., Oechel, W., Tenhunen, J., Valentini, R., and Verma, S., 2002, Energy balance closure at FLUXNET sites: Agricultural and Forest Meteorology, v. 113, p. 223-243.

Winograd, I.J., and Friedman, I., 1972, Deuterium as a tracer of regional ground-water flow, southern Great Basin, Nevada and California: Geological Society of America Bulletin, v. 83, p. 3,691-3,708.

Winograd, I.J., and Pearson, F.J., Jr., 1976, Major carbon-14 anomaly in a regional carbonate aquifer-Possible evidence for megascale channeling, sough-central Great Basin: Water Resources Research, v. 12, no. 6, p. 1,125-1,143.

Winograd, I.J., Riggs, A.C., and Coplen, T.B., 1998, The relative contributions of summer and cool-season precipitation to groundwater recharge, Spring Mountains, Nevada, USA: Hydrogeology Journal, v. 6, p. 77-93.

Winograd, I.J., and Thordarson, William, 1975, Hydrogeologic and hydrochemical framework, south-central Great Basin, Nevada-California, with special reference to the Nevada Test Site: U.S. Geological Survey Professional Paper 712-C, 126 p., http://pubs.er.usgs.gov/publication/pp712C.

Yang, D., Goodison, B.E., Metcalfe, J.R., Golubev, V.S., Bates, R., Pangburn, T., and Hanson, C.L., 1996, Accuracy of NWS 8" standard nonrecording precipitation gaugeResults and application of WMO intercomparison: Journal of Atmospheric and Oceanic Technology, v. 15, p. 54-68. 

Publishing support provided by the U.S. Geological Survey

Science Publishing Network, Tacoma Publishing Service Center

For more information concerning the research in this report, contact the Director, Nevada Water Science Center

U.S. Geological Survey

2730 N. Deer Run Rd.

Carson City, Nevada 89701

https://nevada.usgs.gov 
